\title{
Materials and Fuels Complex FY-19-FY-23 Five-Year Investment Strategy
}

April 2019

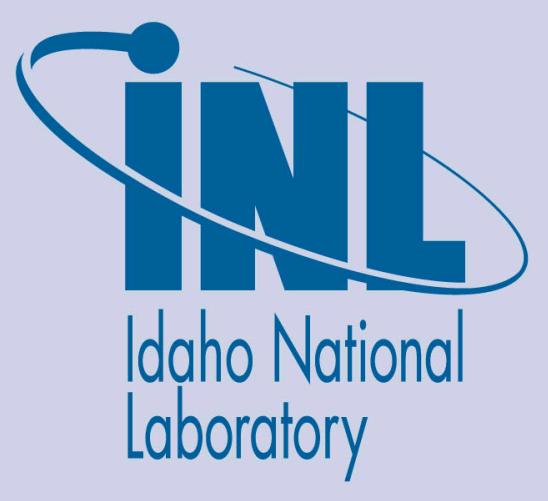

The INL is a U.S. Department of Energy National Laboratory operated by Battelle Energy Alliance 


\section{DISCLAIMER}

This information was prepared as an account of work sponsored by an agency of the U.S. Government. Neither the U.S. Government nor any agency thereof, nor any of their employees, makes any warranty, expressed or implied, or assumes any legal liability or responsibility for the accuracy, completeness, or usefulness, of any information, apparatus, product, or process disclosed, or represents that its use would not infringe privately owned rights. References herein to any specific commercial product, process, or service by trade name, trade mark, manufacturer, or otherwise, does not necessarily constitute or imply its endorsement, recommendation, or favoring by the U.S. Government or any agency thereof. The views and opinions of authors expressed herein do not necessarily state or reflect those of the U.S. Government or any agency thereof. 


\section{Materials and Fuels Complex FY-19-FY-23 Five-Year Investment Strategy}

April 2019

Idaho National Laboratory Idaho Falls, Idaho 83415

http://www.inl.gov

Prepared for the

U.S. Department of Energy

Office of Nuclear Energy

Under DOE Idaho Operations Office

Contract DE-AC07-05ID14517 
MFC FIVE-YEAR INVESTMENT STRATEGY 


\section{CONTENTS}

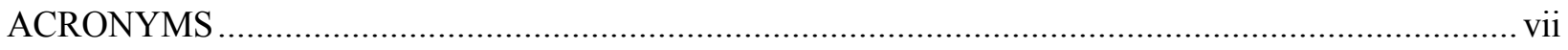

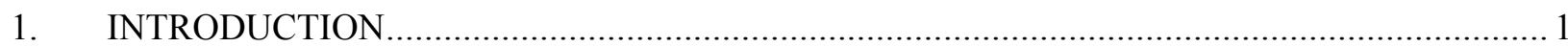

1.1 A Strategy for the Materials and Fuels Complex ..................................................... 1

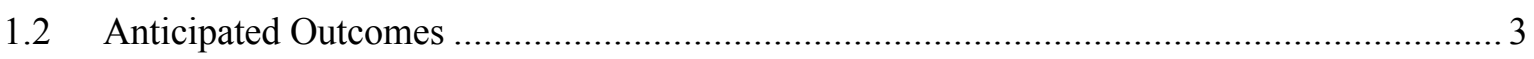

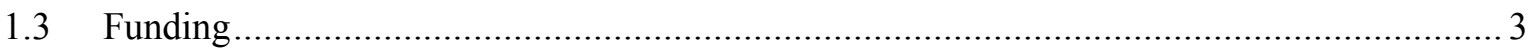

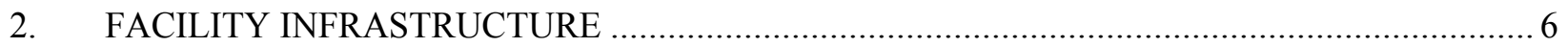

2.1 MFC Base Operations and Maintenance ............................................................... 7

2.2 MFC RD\&D Mission Enablement ........................................................................ 7

2.3 MFC 5-Year Plant Health and RD\&D Capability and Sustainment Investments .................. 8

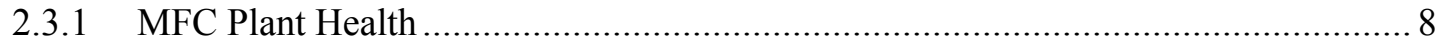

2.3.2 MFC RD\&D Capability Sustainment Investments ............................................ 11

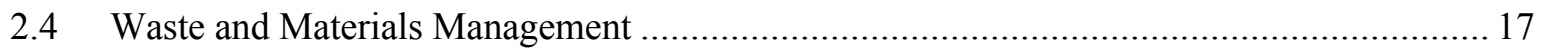

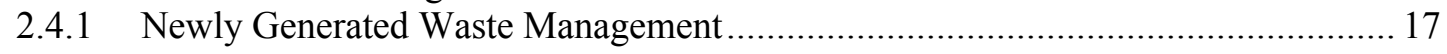

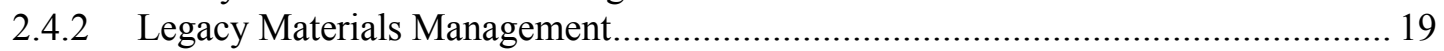

2.4.3 Strategy to Accelerate Production of High Assay Low-Enriched Uranium (HA-LEU) Material ............................................................................... 20

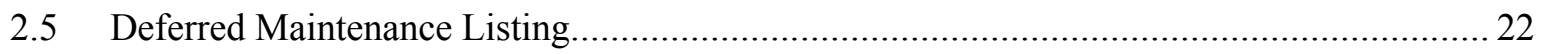

3. INSTRUMENT SCIENTISTS AND NEW INSTRUMENT CAPABILITIES ...........................24

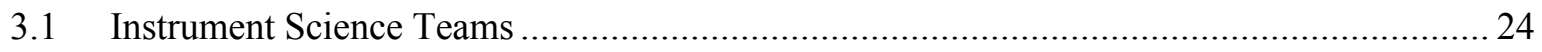

3.2 Scientific Instrument Development Strategy ............................................................ 26

3.2.1 MFC Research Instrumentation Strategy …..................................................... 26

3.2.2 TREAT Reactor Instrumentation Development Strategy...................................... 30

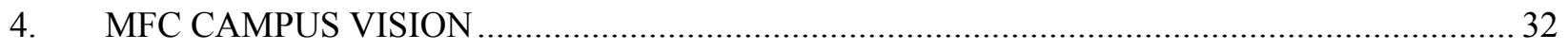

4.1 MFC Capital Asset and Direct Nuclear Infrastructure ................................................ 33

4.1.1 MFC Research Collaboration Building............................................................... 34

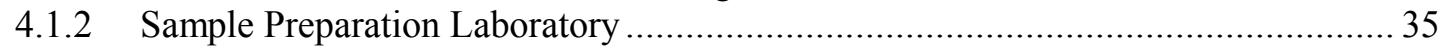

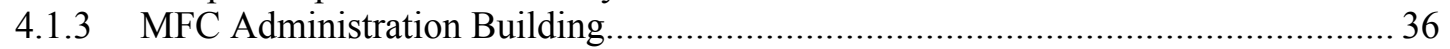

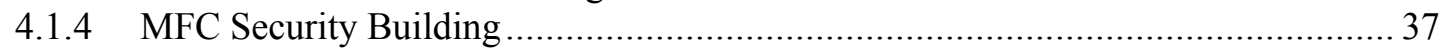

4.1.5 MFC Analytical Laboratory Refurbishment/Expansion ..................................... 38

4.1.6 Engineering Scale Reactor Fuels Fabrication Laboratory ................................... 39

4.2 Nuclear Research Support Infrastructure Refurbishment and Replacement....................... 40

4.3 Repurposing Existing MFC Facilities to Support Growth of the Test Bed ....................... 41

4.4 Laboratory Investments in MFC General Use Infrastructure ........................................... 42

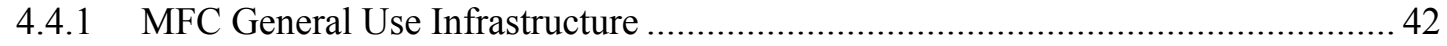

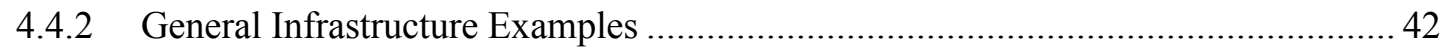

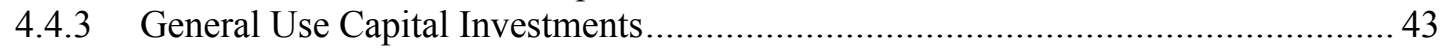

Appendix A Detailed Descriptions of Plant Health Activities ........................................................ 49

Appendix B Detailed Descriptions of Instrument Capability Activities............................................ 89

Appendix C Detailed Descriptions of TREAT Instrument Capability Activities .............................. 127 


\section{FIGURES}

Figure 1. DOE-NE Test Bed and Demonstration Platform Funding Strategy. ...................................... 4

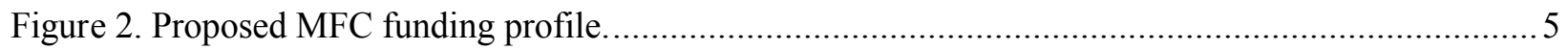

Figure 3. MFC/TREAT Radioactive Waste Disposition Path Flowsheet.............................................. 18

Figure 4. MFC Campus Vision Conceptual Time Frames for Capital Asset and Nuclear Infrastructure.

\section{TABLES}

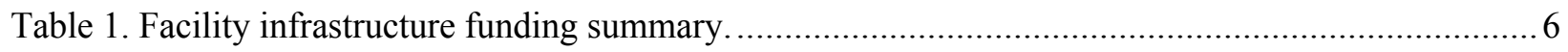

Table 2. Prioritized MFC Plant Health Investment. Cost in thousands (\$K)....................................... 12

Table 3. MFC Materials and Waste Management Funding Profile.................................................... 20

Table 4. Proposed Schedule for Accelerated HALEU Production.......................................................2 21

Table 5. MFC DM Master List as of September 2017 ....................................................................... 22

Table 6. Summary of FY-18-FY-23 instrument development strategy and ROM cost estimates (\$K, FY-18 dollars).

Table 7. Summary of FY-19-FY-23 Transient testing scientific and enabling infrastructure development strategy and ROM cost estimates (\$K, FY-19 dollars). 


\section{ACRONYMS}

AES

$\mathrm{AL}$

ANL

BCS

CAMS

CAS

$\mathrm{CH}$

CLG

D\&D

DDC

DM

DOE

EBR-II

$\mathrm{ECP} / \mathrm{EBL}$

EDGB

EELS

EM

EOL

EPMA

FASB

FCF

FIB

FMF

FFTF

GAIN

GASR

HFEF

HALEU

HVAC

IA

IASCC

ICP

ICP-MS
Atomic Emission Spectroscopy

Analytical Laboratory

Argonne National Laboratory

Building Control System

Continuous Air Monitoring System

Criticality Alarm System

contact-handled

Casting Laboratory Glovebox

decontamination and decommissioning

Direct Digital Controls

Deferred Maintenance

Department of Energy

Experimental Breeder Reactor-II

Element Contact Profilometer/Element Bow \& Length Machine

East Development Glovebox

Electron Energy Loss Spectrometer

Electro-mechanical manipulators

end of life

Electron Probe Micro-Analysis

Fuels and Applied Science Building

Fuel Conditioning Facility

Focused Ion Beam

Fuel Manufacturing Facility

Fast Flux Test Facility

Gateway for Accelerated Innovation in Nuclear

Gas Assay Sample and Recharge

Hot Fuel Examination Facility

high assay low enriched uranium

heating, ventilating, and air conditioning

Instrument Air

irradiation assisted stress corrosion cracking

Inductively Coupled Plasma

Inductively Coupled Plasma Mass Spectrometer 
INL Idaho National Laboratory

LA laser ablation

LFTD laser-flash thermal-diffusivity

LLW low-level waste

MEITNER Modular Examination Instrument for Transportable Nuclear Energy Research

MC-ICP-MS Multi-Collector Inductively Coupled Plasma Mass Spectrometer

MFC Materials and Fuels Complex

MLLW mixed low-level waste

NE Office of Nuclear Energy

ORNL Oak Ridge National Laboratory

PIE post-irradiation examination

RAMS Radiation Area Monitoring System

RD\&D research, development, and demonstration

RDD\&D research development, demonstration, and deployment

RH remote-handled

RLWTF Radioactive Liquid Waste Treatment Facility

RN Repair Needs

ROM rough-order of-magnitude-Generally engineering judgement estimates for conceptual purposes with a range of $-50 \% /+100 \%$. Used as a placeholder prior to initiating planning activities.

SC-ICP-MS Single Collector Inductively Coupled Plasma Mass Spectrometer

SEM Scanning Electron Microscopy

SPG Special Project Glovebox

SSC structure, system, and component

SSPSF Space and Security Power Systems Facility (at MFC)

TCM Thermal Conductivity Microscope

TEM Transmission Electron Microscopy

TIMS thermal ionization mass spectroscopy

TREAT Transient Reactor Test Facility

TRIGA Training, Research, Isotope, and General Atomics

VFD variable frequency drive

VTR Versatile Test Reactor

WIPP Waste Isolation Pilot Plant

WMP Waste Management Program

ZPPR Zero Power Physics Reactor 


\section{INTRODUCTION}

The Department of Energy Office of Nuclear Energy (DOE-NE) mission is to provide the research, development, and demonstration foundation to extend the lives of the current operating reactor fleet, develop the next generation of nuclear reactors, and provide integrated nuclear fuel cycle solutions. The Materials and Fuels Complex (MFC) serves as the foundation of a nuclear research, development, and demonstration (RD\&D) enabling test bed at Idaho National Laboratory (INL) and is an integral part of a National Reactor Innovation Center strategy. MFC facilities focus on developing and maintaining RD\&D capabilities that can increase research throughput, reduce barriers to deployment, and facilitate commercialization of new ideas and technologies for clean and secure sources of energy.

This document is a complimentary document to the Materials and Fuels Complex Integrated FiveYear Science Strategy (INL/EXT-19-52612) that defines specific implementation strategies for increasing research capability and throughput through targeted investments in research facilities, research instruments, and research staff.

Refer to INL/EXT-19-52612 for details about MFC, its capabilities, and the overall science strategy for the Materials and Fuels Complex.

\subsection{A Strategy for the Materials and Fuels Complex}

MFC will continue its support of current RD\&D missions while enabling new projects and missions working with DOE-NE partners, industry and academia. The strategy described in this document will guide the efforts to build, expand, and sustain DOE-NE research capabilities at MFC, increase access to MFC capabilities by industry and the nuclear RD\&D community, and revitalize the existing MFC nuclear infrastructure. The strategy also anticipates and guides the preparations necessary for demonstration of advanced nuclear energy technologies in support of a National Reactor Innovation Center (NRIC) concept, the DOE Gateway for Accelerated Innovation in Nuclear (GAIN) initiative, and nuclear energy and other related critical outcomes identified in the Idaho National Laboratory (INL) Laboratory Agenda.

MFC's core research and/or production competencies exist in the following areas:

- Nuclear fuels and cladding

- Radiation damage in core structural materials

- Advanced manufacturing for nuclear fuel and cladding

- Chemical separations and fuel recycling

- Focused basic research that advances the applied technology mission

- Nuclear nonproliferation and nuclear forensics

- Space nuclear power and isotope technologies

- Transient testing of reactor fuels.

The strategy for MFC entails building and improving on these core competencies, introducing new and revitalized RD\&D capabilities, and maturing the NRIC test bed. MFC is also implementing new business and operations models to help transform MFC into a complex that supports an advanced nuclear technology development test bed. The strategy for MFC is presented in several parts, each focusing on an element needed for success. 
Key features of this strategy include the following:

- RD\&D Capability Development, Optimization, and Integration - This emphasizes research and capability development in areas where MFC has a core strength. Collaborating with NS\&T and NHS, prioritizing and pursuing funding for construction of needed capabilities where national gaps exist and leveraging the key GAIN partnerships with Oak Ridge National Laboratory (ORNL), Argonne National Laboratory (ANL), and others as well as enhancing relationships and furthering partnerships with DOE-NE's extended research network fills capability gaps that will not be added to MFC. Improving or establishing relationships with U.S. universities to further extend MFC's research network, provide a pipeline for recruiting future staff, and positively influence educational programs whenever possible and providing additional collaboration pathways with the international community through INL's designation as an International Centre based on Research Reactor (ICERR) by the International Atomic Energy Agency (IAEA) are also key components.

- Base Operations, Plant Health, and RD\&D Capability Sustainment - This emphasizes executing efficient base operations as a core foundation to RD\&D execution excellence. A portion of this includes reviving and improving historical MFC capabilities that support demonstration-scale activities and improving facility reliability through targeted replacement and improvement of facility systems. This supports DOE-NE programmatic objectives by maintaining, improving, and constructing new support infrastructure, as needed, to ensure the safe operation of MFC.

- Implementing a New MFC-Wide Operating Model - Implementing an operations model that improves the efficiency, reliability, and safety of MFC operations and sustains and advances RD\&D execution excellence. This model ensures that predictable and reliable base funding exists to support a core team of expert RD\&D support staff. A user facility-like model increases research capacity and improves access to nuclear RD\&D capability at MFC. It ensures state-of-the-art research capabilities are available to effectively operate a test bed capability as envisioned by GAIN and serve as a foundation of the NRIC.

This strategy will position INL and its sponsor, DOE-NE, to deliver an effective nuclear RD\&D capability in support of current programs and further build an accessible, comprehensive, reliable, and cost-effective nuclear demonstration capability that supports deployment of nuclear technology. This capability will play a key role in developing advanced nuclear technology concepts that can positively impact the ability of U.S. nuclear energy technology to keep pace with a changing world energy market.

This document includes:

- A description of MFC facility infrastructure support needs in Section 2

- A description of MFC scientific infrastructure support needs in Section 3

- A forward-looking vision for development of the MFC campus in Section 4

- Details of specific plant health and RD\&D capability target areas in Appendix A and B.

- Detailed descriptions of TREAT instrument capability activities in Appendix C.

NOTE: The cost estimates listed in this document, in particular the tables in Sections 2 and 3, were based upon best engineering judgement at the time the scope was identified by the Mission Directors. In every case the cost estimates will change as work proceeds through planning and then execution. The intent of these tables is to provide a strategic context on what areas within MFC facility and scientific infrastructure have been identified as important to address facility reliability, RD\&D capability sustainment, and capability growth to support the test bed and NRIC concept. 


\subsection{Anticipated Outcomes}

MFC recognizes that implementing this strategy requires significant investment. This commitment is not taken lightly. As with any investment, a return on that investment is expected. Implementing this strategy will result in the following outcomes:

- Increased facility and equipment reliability and availability, reducing the experiment lifecycle of RD\&D critical to DOE-NE and other missions

- More efficient operations, increasing the amount of critical knowledge gained per dollar spent on research

- A wider range of RD\&D capabilities that support a range of objectives from scientific discovery and model validation to demonstration and licensing

- Increased capability to support the Nuclear Energy R\&D Test Bed concept in a reliable manner. MFC performance metrics will focus on factors important to supporting MFC's nuclear energy RD\&D mission. Metrics (current or being developed) will target the following areas:

- Reduction of deferred maintenance and repair needs - Documented levels of deferred maintenance in the Facility Information Management System will be reduced.

- Facility availability - The percentage of time major facilities are available to support RD\&D will increase with increased reliability of key operational systems in the R\&D facilities.

- Instrument/equipment utilization - Utilization of key RD\&D instruments will be tracked to provide data for identifying instrument reliability, performance, and resource issues and to help with future planning for instruments and personnel resources.

- Expanded Research Staff to Enable the R\&D Test Bed - This measures increases in scientific staff needed to provide comprehensive growth of scientific support of test bed capabilities.

- Quality, relevance, and impact of research output - Metrics used to demonstrate an increase in the contribution MFC is making to nuclear energy knowledge includes the following:

- Completion of MFC mission outcomes

- Number and quality of peer-reviewed publications and reports

- $\quad$ Number of external users relying on MFC RD\&D capabilities

- Positive feedback from customers (e.g., NS\&T, NHS, and external industry, small business, and university users).

A baseline for many of these metrics was established. A primary goal will be to double MFC research throughput over its current level by the end of FY-22, as measured by instrument utilization and research output metrics.

\subsection{Funding}

MFC is the hub of the DOE-NE test bed and NRIC. The funding strategy below aligns MFC with the overall DOE-NE objective of developing a nuclear energy test bed that can enable innovative nuclear energy technology to pass swiftly through the technology readiness levels and position this new technology for deployment into the commercial sector as a safe cost competitive carbon free energy source. 
Figure 1 provides a diagram of the proposed funding strategy. Elements shaded blue are proposed to be funded by the IFM program and the green shaded element should be supported by NE RD\&D programs. Overall funding levels to build an effective test bed and to re-establish DOE-NE as the world leader in innovative nuclear energy technology are identified in Figure 2.

INL's ability to perform world class research and development depends on maintaining nuclear RD\&D facilities, scientific instruments, necessary scientists and staff to support greater science throughput and shorten the experiment lifecycle

\section{MFC Nuclear Energy Test Bed and Demonstration Platform Infrastructure}

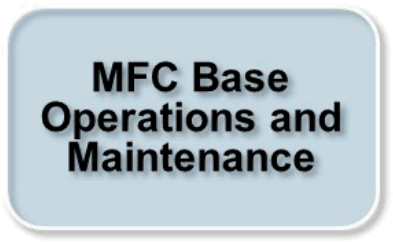

- Base funding to support research facility operations and maintenance such as fully qualified facility, reactor, and hot cell staff to operate, engineer, maintain, and support mission execution.

- Maintenance of nuclear research facilities and support systems safety bases, TSRs, and all other operating permit conditions

- MFC 5YP plant health and RD\&D capability sustainment investments to improve facility reliability and availability and sustain experiment infrastructure.

- Includes Site Treatment Plan, EBR-II disposition, and SNM management

MFC RD\&D Mission Enablement

\section{Instruments Scientists and New Instrument Capabilities}

- Maintaining the technical and operational readiness of existing RD\&D capabilities and support systems over the full spectrum of RD\&D from basic research to preparation for deployment.

- RD\&D instrument operations and maintenance to ensure a mission ready capability, instrument performance specifications and instrument service contracts.

- Covers existing support infrastructure such as test loops and associated instrumentation, manipulators, windows, gloveboxes, lighting, safety basis, procedures, etc. to ensure safe and reliable performance.

- Fully qualified scientists to perform science, ensure the lab has subject matter expertise, develop instruments and techniques, and collaborate with and grow the user community

- New instruments and systems necessary to expand the nuclear energy test bed and demonstration platform capabilities.

Figure 1. DOE-NE Test Bed and Demonstration Platform Funding Strategy. 


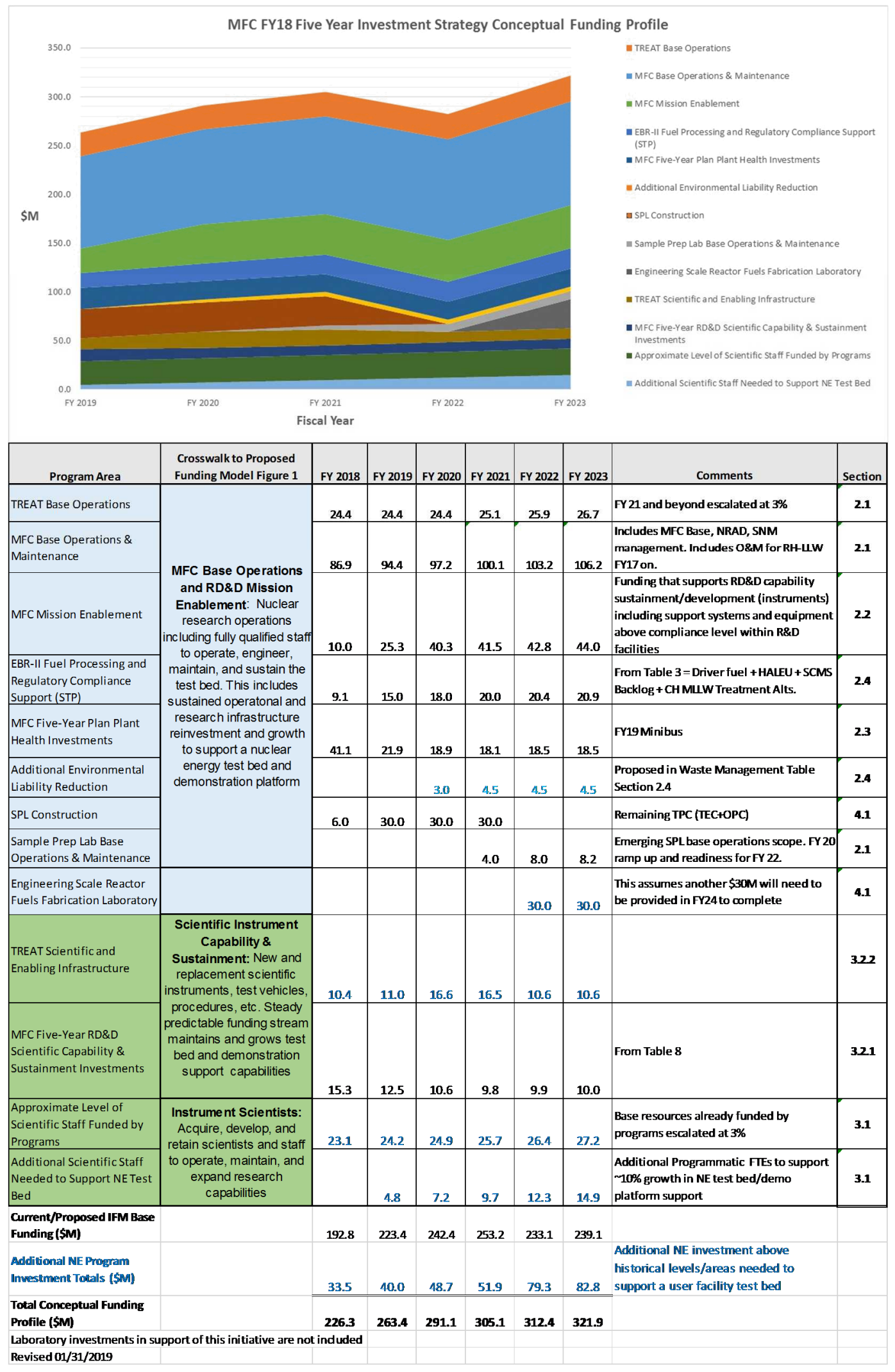

Figure 2. Proposed MFC funding profile. 


\section{FACILITY INFRASTRUCTURE}

Facility Infrastructure is made up of four primary components:

1. MFC Base Operations and Maintenance - This area provides compliance level support to maintain MFC nuclear and radiological facilities at a safe, stable, and compliant state of readiness to accept work. This includes TREAT base operations listed separately in the table below. (Subsection 2.1)

2. MFC RD\&D Mission Enablement - This area provides the funding above compliance level that supports operating, maintaining, and sustaining the current RD\&D instruments and support systems at a mission readiness level to be ready to support RD\&D mission execution. (Subsection 2.2)

3. MFC Five-Year Strategy Plant Health and RD\&D Capability Sustainment Investments - These are investments into plant systems and infrastructure above historical levels of corrective and predictive maintenance. These investments are also focused on refurbishment and replacement of aging instruments and plant systems that can impact facility reliability and availability and negatively affect mission execution and RD\&D outcomes. (Subsection 2.3)

4. Waste and Materials Management - These activities support meeting regulatory agreements between DOE and government entities such as the Idaho Settlement Agreement and Site Treatment Plan. This also includes activities executed to reduce the legacy liability of INL. (Subsection 2.4)

A funding profile is shown in Table 1. These funding levels support the reliable infrastructure necessary to provide a mature test bed and demonstration capability.

Table 1 . Facility infrastructure funding summary.

\begin{tabular}{|l|c|c|c|c|c|}
\hline \multicolumn{1}{|c|}{ Area } & FY-19 & FY-20 & FY-21 & FY-22 & FY-23 \\
\hline $\begin{array}{l}\text { MFC Base Operations and } \\
\text { Maintenance } \\
\text { MFC O\&M including NRAD and SNM } \\
\text { management plus the addition of RH- } \\
\begin{array}{l}\text { LLW Disposal Facility and SNM } \\
\text { management. }\end{array}\end{array}$ & $\$ 94,400$ & $\$ 97,232$ & $\$ 100,149$ & $\$ 103,153$ & $\$ 106,248$ \\
\hline MFC Mission Enablement & $\$ 25,300$ & $\$ 40,300$ & $\$ 41,509$ & $\$ 42,754$ & $\$ 44,037$ \\
\hline $\begin{array}{l}\text { MFC Five-Year Strategy Plant Health } \\
\text { and RD\&D Capability Sustainment } \\
\text { Investments }\end{array}$ & $\$ 34,350$ & $\$ 29,425$ & $\$ 27,905$ & $\$ 28,360$ & $\$ 29,211$ \\
\hline $\begin{array}{l}\text { TREAT Base Operations } \\
\text { Base O\&M of TREAT }\end{array}$ & $\$ 24,400$ & $\$ 24,400$ & $\$ 25,132$ & $\$ 25,886$ & $\$ 26,663$ \\
\hline $\begin{array}{l}\text { Waste and Materials Management } \\
\text { Includes Site Treatment Plan CH-MLLW } \\
\text { \& RH-MLLW, Nuclear Materials } \\
\begin{array}{l}\text { Management, EBR-II Disposition, and } \\
\text { HALEU }\end{array}\end{array}$ & $\$ 15,493$ & $\$ 20,173$ & $\$ 22,159$ & $\$ 22,658$ & $\$ 23,338$ \\
\hline $\begin{array}{l}\text { Total Facility Infrastructure Funding } \\
\text { (\$K) }\end{array}$ & $\mathbf{\$ 1 9 3 , 9 4 3}$ & $\mathbf{\$ 2 1 1 , 5 3 0}$ & $\mathbf{\$ 2 1 6 , 8 5 4}$ & $\mathbf{\$ 2 2 2 , 8 1 2}$ & $\$ \mathbf{\$ 2 2 9 , 4 9 6}$ \\
\hline
\end{tabular}




\subsection{MFC Base Operations and Maintenance}

Base operations funding provides the resources needed to maintain nuclear and radiological facilities in a compliant state of readiness to accept work. Very little of this base workscope is discretionary. This state of readiness has historically been defined as maintaining the facilities in a safe, compliant, and stable configuration within the established safety bases and regulatory framework to be available to support RD\&D programs. Proposed changes to base operations includes investments in facility and instrument enablement discussed in Subsections 2.2 and 2.3.

Execution within the base operations framework includes managing the operations, maintenance, and support of nuclear facilities and resources to be ready to enable the conduct of advanced nuclear energy research at MFC.

Specific tasks include:

- Performing surveillance, maintenance, and operation activities required to control existing material and waste, and to maintain facilities in a safe and stable condition

- Ensuring regulatory requirements are met related to health and safety, nuclear safety (facility authorization basis), criticality safety, and safeguards and security

- Ensuring compliance with state and federal environmental and operating permit requirements

- Performing the engineering for structure, system, and component (SSC) modifications and upgrades necessary to ensure safety and functionality

- Enabling specific activities such as establishing an equipment reliability program, improving configuration management and plant health monitoring that efficiently ensures reliability of SSCs and the efficiency and safety in which maintenance and engineering changes are performed.

In addition, targeted major maintenance and repair is performed to address SSC degradation in order to ensure facility availability and throughput. Targeted major maintenance and repair efforts (described in Section 3) include hot cell window replacements, manipulator upgrades, and Analytical Laboratory (AL) HVAC replacement. These upgrades will result in a reduction in MFC deferred maintenance (DM) and key repair needs (RN). This funding will allow these facilities to sustain multiple shifts and to handle the increased maintenance burden as they are operated at increased capacity. Additional engineering and other technical support resources will be needed to address the technical issues associated with operating multiple shifts into aging facilities to meet mission demands.

\subsection{MFC RD\&D Mission Enablement}

Implementing a sustainable and reliable nuclear RD\&D capability requires a funding model that supports effective and efficient management of research instruments and research facilities critical to execution of the current DOE-NE research portfolio and in support of an expanded mission anticipated through the GAIN initiative. RD\&D Mission Enablement provides the foundation for a comprehensive, reliable, and sustained research capability and a stable environment for recruiting, retaining, training, and improving the expertise of the scientific and support work force.

The proposed RD\&D mission enablement activities support technical and operational readiness of RD\&D capabilities (instruments) and the associated support systems including:

- Operation of instruments to develop new methods and techniques while not performing direct program work

- Maintenance of instruments including instrument service contracts (vendor maintenance agreements) to ensure performance specifications are maintained

- Upgrade and develop unique instrument applications to ensure world class instrument and process performance 
- Feasibility and safety evaluations for the use of various fuels and materials configurations

- Support for general user program relative to experiment setup and data analysis

- Training of staff and users in the operation or maintenance of instruments

- Maintenance, operation, and engineering of support systems such as inert gas, manipulators, windows, gloveboxes and lighting to ensure safety and reliable performance

- Performance testing of integrated instrument systems

- Coordination and logistical support for instrument usage, maintenance, and testing

- Commodity usage such as gas and chemicals that support instrument usage

- Maintenance on in-cell/glovebox utilities and equipment that support instrument and RD\&D capabilities such as cranes, feedthroughs and process instrumentation

- Maintaining inter-facility transport capabilities

- Operating and maintaining data and control networks.

Establishing a robust, direct-funded mission enablement platform is a key element in transition to a user facility model that has been successfully deployed in many government-sponsored research facilities and is critical to improve research throughput and efficiency. Steady and reliable mission enablement funding ensures that RD\&D capabilities including instruments and scientific and technical resources, are available to support DOE-NE mission execution. This eliminates the uncertainty associated with programmatic fund sources and ensures that facilities and instruments are maintained as world-class and mission ready with the necessary technical expertise to enable mission success. IFM funding has been allocated to commence this in FY-18. Additional funding was authorized in FY-19 to commence this migrations towards a user facility-like model. Completing this transition is proposed for FY-20. This approach will dramatically increase throughput and reduce the experiment life-cycle time. Additionally, the U.S. ability to lead collaborative efforts will be instrumental in reestablishing U.S. leadership in advanced nuclear energy technologies and research techniques.

\subsection{MFC 5-Year Plant Health and RD\&D Capability and Sustainment Investments}

\subsubsection{MFC Plant Health}

MFC plant health investments are a key aspect of a healthy and efficient NE RD\&D test bed model and serves as the foundation of the NRIC. This requires dedicated and sustained funding to address MFC's plant health needs. The MFC investment strategy identifies the highest priority risks to facility reliability and RD\&D experiment throughput and proposes a multi-year strategy to address these risks. The strategy also addresses deferred maintenance (DM) across all MFC nuclear and radiological facilities. Priorities are established by analysis of overall risk to facility availability and system reliability. The total integrated plant health and RD\&D capability/sustainment requests are detailed on Tables 2 and 6 and TREAT specific investments are included in Table 7. These investments enable increased facility reliability, increased research throughput, expanded test bed capacity, and a reduction of DM (a complete listing is in Table 4). 
MFC is implementing a disciplined process to identify and assign a relative priority to plant health issues utilizing a MFC Complex Health Committee (CHC) prioritization process. This process is designed to identify and prioritize risks to facility reliability and RD\&D mission execution with a goal of ensuring facility reliability risks are identified and addressed before impacts to facility availability or RD\&D capability occur. Steady and reliable funding to support a sustained plant health campaign is a critical aspect of the new test bed model and is essential to enable higher RD\&D throughput and mission execution success.

Two of MFC's flagship facilities, HFEF and AL, have repair needs and deferred maintenance that are key to DOE's overall mission accomplishment. Some aspect of much of the research executed by MFC is dependent upon the capabilities located in these two facilities. HFEF and AL are where the initial focus on plant health began. These activities will be integrated with other current priorities or emergent issues in the other research facilities.

HFEF is DOE-NE's core PIE facility. This five-year strategy will address deficiencies in HFEF systems that currently limit research throughput and will ensure that MFC's support for DOE's mission is not negatively impacted. Critical HFEF systems and research equipment are being refurbished and replaced to increase facility reliability and experiment throughput. Systems such as the argon supply for the HFEF hot cell have not been refurbished since the facility opened and are single point failure risks to RD\&D operations. Equipment such as the 40 -ton high bay crane, currently being overhauled, exhibited a variety of age-related issues, such as trucks climbing up on rails due to crabbing of the trolley and an obsolete control system that exhibits frequent failure is being refurbished to address risks to facility reliability.

The HFEF main cell pressure/temperature, purification, and compressed argon systems use obsolete technology. Key components are exhibiting increasing failure rates many times spares are not available or require a vendor to custom fabricate special-order spares on a limited basis. This approach to patching the system is expensive, time consuming, and does not fundamentally resolve the reliability issues. Current efforts to update these systems will minimize future programmatic impacts due to system reliability.

HFEF electrical systems have, for the most part, remained unchanged and have only had minor modifications performed since HFEF was constructed in the1970s. System failures are increasing and spare parts and vendor support is rapidly disappearing; there are no spares available for the breaker panels and motor control centers.

Key equipment such as the HFEF polisher/grinder, a "gateway" piece of equipment supporting sample preparation for all in-cell microscopy is being replaced, as is the Gas Assay Sample and Recharge (GASR) system, which is an aging, unique, and critical piece of $R \& D$ process equipment. HFEF is also replacing aging back up power generators which will be relocated to a pre-engineered electrical building adjacent to HFEF from the HFEF basement. This frees up footprint for HFEF to expand test bed capabilities related to the neutron beam lines associated with NRAD.AL is MFC's principle facility for conducting analytical chemistry and experimental data analysis on nuclear fuels and materials. AL received its first hot fuel sample from the Experimental Breeder Reactor-II in 1964 and has been in continuous operation ever since. AL is a Hazard Category 3 Nuclear Facility with approximately 10,000 $\mathrm{ft}^{2}$ of laboratory space. The AL HVAC system is no longer capable of supporting additional research or analytical capability and currently operates at maximum capacity. The HVAC system is being refurbished and upgraded to support growth in RD\&D capabilities and increase facility reliability. AL is also executing lab renovations and fume hood replacement throughout the facility to modernize the labs and increase operating efficiency. 
Four of the gloveboxes in use at AL (casting lab, special projects, waste form testing, and radiochemistry) need either replacement or significant overhaul. Part of the comprehensive plant health strategy includes addressing these gloveboxes to ensure the facility is in the best possible condition to support new fuels development in its pre- and post-irradiated forms, fuel separations, and waste form development.

The HFEF, FCF, and AL master/slave manipulators and electro-mechanical manipulators (EMM) are key systems that move equipment and material and execute RD\&D within the MFC hot cells. These are aging and replacement components are difficult or impossible to acquire. Each set of manipulators services a unique capability(s) within the facility hot cells; manipulator failures remove that particular capability from service and impact mission execution. To address a large portion of this issue, MFC has partnered with a vendor to design and fabricate the next generation of manipulators. An overall strategy to address manipulators across MFC is detailed in PLN-5568, "MFC Manipulator Strategy." This plan is phased over several years and will eventually result in replacement of all manipulators with reliable nextgeneration equivalents.

The hot cell windows at HFEF and FCF were fabricated over 50 years ago. These windows are 4-ft thick and comprise tank units filled with alternating layers of glass and mineral oil. Several of the units are leaking mineral oil, which requires resources to manage and mitigate the impacts, increasing cost and decreasing efficiency of operations. An ongoing window replacement campaign staged over several years targets HFEF, FCF, and AL hot cell windows.

Ongoing investment in data communications infrastructure (wired and wireless) is necessary to improve overall effectiveness and efficiency at MFC. Cyber security considerations must also be assessed and managed to support secure execution of the RD\&D mission. The MFC private facility control network $(\mathrm{PFCN})$ is a primary aspect of maintaining secure cyber systems across MFC. Continued update and refurbishment of communications and cyber infrastructure enable safety, security, and mission effectiveness and becomes more urgent as technology advances and communication, cyber security, and data management needs increase.

FCF priorities include addressing the facility control system for hot cell operations. The first phase funded in FY-19 replaces the programmable logic controllers for the system. These are producing spurious failure notifications decreasing facility reliability and requiring significant time and effort to troubleshoot and address. Follow on phases will include small logic controllers (SLC's) and other process control systems. The reliability of the high bay crane and replacement of the Truck Lock Industrial Waste Holding Tank will also be addressed in the future.

FMF and ZPPR facilities need replacement of the current criticality alarm systems (CAS). These are funded in FY-19 and are in design by the vendor. The FMF HVAC system also needs refurbishment. FMF and ZPPR roofs are aging and requiring significant resources to address infiltration of precipitation during different parts of the year and design is underway to address these in FY-19.

Many legacy items in the research facilities and support areas can be removed and dispositioned. This increases overall mission execution efficiency and frees up additional critical nuclear facility RD\&D space critical to support test bed growth. The FMF Waste Characterization Glovebox, AL Waste Form Glovebox, and AL Cell \#1 Glovebox could all be removed and dispositioned providing critical additional RD\&D space. A separate funding source (limited DOE-EM funding to address D\&D of INL systems and facilities) is addressing the FMF Waste Characterization Glovebox and FASB East Development Glovebox in FY-19 while other areas have not yet been prioritized within current funding.

A sustained plant health campaign ensures aging infrastructure at MFC remains reliable and available to support DOE-NE mission execution and can support the additional RD\&D capacity and capabilities anticipated as the test matures. 


\subsubsection{MFC RD\&D Capability Sustainment Investments}

MFC RD\&D capability sustainment investments are focused on sustaining RD\&D capabilities through instrument replacement, refurbishment, and occasionally enhancement as analytical capability within the industry matures and develops. This is a new area of focus with limited investment commencing in FY-18. This area recognizes the DOE-NE commitment to sustaining world-class nuclear RD\&D capabilities across MFC's current areas of expertise. This is in contrast to investment into research and development of prototype analytical or PIE systems that will be referred to in this strategy as RD\&D Capability Development and expected to be funded by DOE-NE research programs investment or laboratory investment.

Some notable variations that make up this five year strategy include two areas of investment IFM committed to lead. These are supporting completion of the IMCL thermal properties cell and installing the first suite of instrumentation; and establishing the first suite of advanced fuel fabrication capabilities. This decision establishes essential new RD\&D test bed capabilities that no single research program is able to fund.

Sustainment areas within AL focus on replacement and addition of mass spectrometry capability to support AL operations. This strategy includes replacement of an aging, single-point-failure risk ICP-MS that is considered a "work horse" instrument in AL. Another AL emphasis is providing more robust and efficient analytical support to RD\&D programs with laser ablation-laser induced breakdown spectroscopy and time-of-flight mass spectrometry that have been purchased in FY-18 and planned for installation in FY-19.

A significant investment in FY-18 and FY-19 is adding new advanced manufacturing capabilities for nuclear fuel fabrication. This includes zone refining, melt pool crystal grower, dry bag isostatic press, casting furnace, laser welder, and 3D printing capabilities. Many of these are first of a kind capabilities for nuclear fuels development. HVAC modifications in the Advanced Fuels Facility (AFF) are also being executed in FY-19 so support capability growth in this important test bed arena.

HFEF RD\&D sustainment activities include refurbishment of the East Radiography Station elevator which is still original equipment installed in 1980 and has no commercially available spares. Several functions are out of service and an upgraded elevator and control system provides more efficient and reliable support for this non-destructive PIE capability. Another area is restoring and upgrading the north beam line in HFEF. The North Radiography Station is also 1980 original equipment with several out-ofservice functions. This effort includes removal of old, out-of-service HFEF equipment, discussed earlier, increasing the available footprint to support expansion of beam line mission support of RD\&D.

Replacing the SEM at FASB ensures this critical capability, currently $100 \%$ fully utilized at MFC, is available to support increasing RD\&D work requests. This also provides a redundant capability increasing experiment throughput and reliability.

Subsection 3.2 provides a detailed list of MFC five-year RD\&D needs and identifies areas of capability development and sustainment targets. 
Table 2. Prioritized MFC Plant Health Investment. Cost in thousands (\$K).

\begin{tabular}{|c|c|c|c|c|c|c|c|c|c|c|c|}
\hline $\begin{array}{c}\text { MFC } \\
\text { Overall } \\
\text { Priority }\end{array}$ & $\begin{array}{l}\text { Asset } \\
\text { Name }\end{array}$ & Name & DM & FY-18 & FY-19 & FY-20 & FY-21 & FY-22 & FY-23 & Outyears & $\begin{array}{c}\text { Est. Total } \\
\text { Cost } \\
(\text { FY-18 \$) } \\
\end{array}$ \\
\hline 1 & $\mathrm{AL}$ & $\begin{array}{l}\text { Replace or } \\
\text { Upgrade the AL } \\
\text { HVAC System }\end{array}$ & No & $\$ 10,000$ & & & & & & & $\$ 10,000$ \\
\hline 2 & $\mathrm{AL}$ & $\begin{array}{l}\text { Lab B-103 } \\
\text { Refurbishment }\end{array}$ & & & & $\$ 1,200$ & & & & & \\
\hline 3 & $\mathrm{AFF}$ & $\begin{array}{l}\text { AFF } \\
\text { Modifications } \\
\text { (HVAC) }\end{array}$ & No & & $\$ 3,000$ & & & & & & $\$ 3,000$ \\
\hline 4 & $\begin{array}{l}\mathrm{HFEF} / \\
\mathrm{FCF} / \mathrm{AL}\end{array}$ & $\begin{array}{l}\text { Manipulator } \\
\text { Replacement } \\
\text { Campaign in } \\
\text { HFEF, FCF, and } \\
\text { AL }\end{array}$ & No & $\$ 3,000$ & $\$ 3,000$ & $\$ 2,500$ & $\$ 4,000$ & $\$ 4,000$ & $\$ 2,200$ & & $\$ 18,700$ \\
\hline 5 & $\begin{array}{l}\mathrm{HFEF} / \\
\mathrm{FCF} / \mathrm{AL}\end{array}$ & $\begin{array}{l}\text { Window } \\
\text { Replacement } \\
\text { Campaign in } \\
\text { HFEF, FCF, and } \\
\text { AL }\end{array}$ & Yes & $\$ 2,500$ & $\$ 2,500$ & $\$ 2,000$ & $\$ 2,000$ & $\$ 2,000$ & $\$ 2,000$ & & $\$ 13,000$ \\
\hline 6 & HFEF & $\begin{array}{l}\text { Argon Cell } \\
\text { Temperature and } \\
\text { Pressure } \\
\text { Controls } \\
\end{array}$ & No & $\$ 1,500$ & & & & & & & $\$ 1,500$ \\
\hline 7 & $\begin{array}{l}\mathrm{FMF} / \\
\mathrm{ZPPR}\end{array}$ & $\begin{array}{l}\text { Replace the } \\
\text { Criticality Alarm } \\
\text { System (CAS) in } \\
\text { FMF and ZPPR }\end{array}$ & No & $\$ 2,000$ & & $\$ 1,200$ & & & & & $\$ 3,200$ \\
\hline 8 & HFEF & $\begin{array}{l}\text { Facility Out-of- } \\
\text { Cell 40-Ton } \\
\text { High Bay Crane }\end{array}$ & Yes & $\$ 2,500$ & & & & & & & $\$ 2,500$ \\
\hline 9 & $\begin{array}{l}\mathrm{HFEF} / \\
\mathrm{IMCL}\end{array}$ & $\begin{array}{l}\text { Compressed } \\
\text { Argon Supply } \\
\text { System } \\
\end{array}$ & Yes & $\$ 700$ & & & & & & & $\$ 700$ \\
\hline 10 & FCF & $\begin{array}{l}\text { Multi-Function } \\
\text { Furnace }\end{array}$ & New & $\$ 6,000$ & & & & & & & $\$ 6,000$ \\
\hline 11 & $\begin{array}{l}\mathrm{HFEF} / \\
\mathrm{FCF} / \mathrm{AL}\end{array}$ & $\begin{array}{l}\text { Radioactive } \\
\text { Liquid Waste } \\
\text { Treatment } \\
\text { Facility } \\
\text { Process/Storage } \\
\text { Tanks } \\
\text { Alternatives } \\
\text { Analysis and } \\
\text { Replacement }\end{array}$ & Yes & $\$ 3,000$ & & & & & & & $\$ 3,000$ \\
\hline 12 & HFEF & $\begin{array}{l}\text { Small Transfer } \\
\text { Lock Doors }\end{array}$ & Yes & $\$ 600$ & & & & & & & $\$ 600$ \\
\hline 13 & HFEF & $\begin{array}{l}\text { Small and Large } \\
\text { Transfer Lock } \\
\text { Drive Control } \\
\text { System Upgrade }\end{array}$ & Yes & $\$ 500$ & & & & & & & $\$ 500$ \\
\hline 14 & $\begin{array}{l}\mathrm{HFEF} / \\
\mathrm{FCF}\end{array}$ & $\begin{array}{l}\text { Electro- } \\
\text { mechanical } \\
\text { Manipulator } \\
\text { Refurbishment }\end{array}$ & No & $\$ 2,000$ & & $\$ 2,000$ & $\$ 2,000$ & $\$ 2,000$ & $\$ 2,000$ & & $\$ 10,000$ \\
\hline 15 & MFC & $\begin{array}{l}\text { Legacy Materials } \\
\text { Disposition }\end{array}$ & No & $\$ 2,000$ & $\$ 2,000$ & $\$ 500$ & $\$ 500$ & & & & $\$ 5,000$ \\
\hline 16 & FCF & $\begin{array}{l}\text { New SCRAPE } \\
\text { Cathode Module } \\
\text { for FCF } \\
\text { Electrorefiner }\end{array}$ & No & $\$ 2,500$ & & & & & & & $\$ 2,500$ \\
\hline
\end{tabular}




\begin{tabular}{|c|c|c|c|c|c|c|c|c|c|c|c|}
\hline $\begin{array}{c}\text { MFC } \\
\text { Overall } \\
\text { Priority } \\
\end{array}$ & $\begin{array}{l}\text { Asset } \\
\text { Name } \\
\end{array}$ & Name & DM & FY-18 & FY-19 & FY-20 & FY-21 & FY-22 & FY-23 & Outyears & $\begin{array}{c}\text { Est. Total } \\
\text { Cost } \\
(\text { FY-18 \$) } \\
\end{array}$ \\
\hline 17 & FCF & $\begin{array}{l}\text { Integrate Bottle } \\
\text { Inspection w/ } \\
\text { Wire Removal } \\
\text { Process } \\
\text { Improvement } \\
\end{array}$ & No & $\$ 1,500$ & & & & & & & $\$ 1,500$ \\
\hline 18 & FCF & $\begin{array}{l}\text { Replace FCF } \\
\text { Facility Control } \\
\text { System }\end{array}$ & Yes & & $\$ 3,000$ & & $\$ 1,800$ & & & & $\$ 4,800$ \\
\hline 19 & $\begin{array}{l}\mathrm{FMF} / \\
\mathrm{ZPPR} \\
\end{array}$ & $\begin{array}{l}\text { Roof- } \\
\text { Replacement }\end{array}$ & Yes & & $\$ 6,000$ & & & & & & $\$ 6,000$ \\
\hline 20 & $\mathrm{AL}$ & $\begin{array}{l}\text { AL Lab Space } \\
\text { Renovation }\end{array}$ & No & & $\$ 450$ & $\$ 400$ & $\$ 400$ & $\$ 400$ & $\$ 400$ & & $\$ 2,050$ \\
\hline 21 & IMCL & $\begin{array}{l}\text { Noise Reduction } \\
\text { Modifications }\end{array}$ & No & & $\$ 350$ & & & & & & $\$ 350$ \\
\hline 22 & IMCL & $\begin{array}{l}\text { Fixed Air } \\
\text { Sampling } \\
\text { System } \\
\end{array}$ & No & & $\$ 250$ & & & & & & $\$ 250$ \\
\hline 23 & IMCL & $\begin{array}{l}\text { IMCL facility } \\
\text { ventilation } \\
\text { system } \\
\text { optimization } \\
\end{array}$ & No & & $\$ 300$ & & & & & & $\$ 300$ \\
\hline 24 & IMCL & $\begin{array}{l}\text { IMCL facility } \\
\text { manipulator } \\
\text { repair capability }\end{array}$ & No & & $\$ 500$ & & & & & & $\$ 500$ \\
\hline 25 & IMCL & $\begin{array}{l}\text { IMCL } \\
\text { Communications } \\
\text { Infrastructure }\end{array}$ & No & & $\$ 300$ & & & & & & $\$ 300$ \\
\hline 26 & IMCL & $\begin{array}{l}\text { IMCL Material } \\
\text { Transfer } \\
\text { Optimization }\end{array}$ & No & & $\$ 200$ & & & & & & $\$ 200$ \\
\hline 27 & Sitewide & $\begin{array}{l}\text { Radiation } \\
\text { Monitoring } \\
\text { Updates } \\
\end{array}$ & No & & & $\$ 1,400$ & $\$ 600$ & $\$ 370$ & & & $\$ 2,370$ \\
\hline 28 & Sitewide & $\begin{array}{l}\text { Refurbish MFC- } \\
\text { Wide Drainage } \\
\text { System (Lab } \\
\text { Investment) } \\
\end{array}$ & No & & $\$ 2,100$ & & & & & & $\$ 2,100$ \\
\hline 29 & Sitewide & $\begin{array}{l}\text { MFC Paving } \\
\text { Repairs/Replace } \\
\text { ment } \\
\text { (Lab Investment) }\end{array}$ & Yes & & $\$ 1,000$ & $\$ 1,000$ & & & & & $\$ 2,000$ \\
\hline 30 & Sitewide & $\begin{array}{l}\text { MFC HVAC } \\
\text { Replacement } \\
\text { Campaign (Lab } \\
\text { Investment) }\end{array}$ & No & & $\$ 400$ & $\$ 400$ & $\$ 400$ & $\$ 400$ & $\$ 400$ & & $\$ 2,000$ \\
\hline 31 & FASB & $\begin{array}{l}\text { Install Pyro- } \\
\text { Chemical } \\
\text { Glovebox (PCG) } \\
\text { in FASB (Lab } \\
\text { Investment) }\end{array}$ & No & $\$ 800$ & $\$ 800$ & & & & & & $\$ 1,600$ \\
\hline 32 & ZPPR & $\begin{array}{l}\text { ZPPR Control } \\
\text { Room Rip Out } \\
\text { (DOE-EM } \\
\text { funded) }\end{array}$ & No & & $\$ 610$ & & & & & & $\$ 610$ \\
\hline 33 & ZPPR & $\begin{array}{l}\text { Waste } \\
\text { characterization } \\
\text { glovebox } \\
\text { removal } \\
\text { (DOE-EM } \\
\text { funded) }\end{array}$ & No & & $\$ 1,400$ & & & & & & $\$ 1,400$ \\
\hline
\end{tabular}




\begin{tabular}{|c|c|c|c|c|c|c|c|c|c|c|c|}
\hline $\begin{array}{c}\text { MFC } \\
\text { Overall } \\
\text { Priority } \\
\end{array}$ & $\begin{array}{l}\text { Asset } \\
\text { Name } \\
\end{array}$ & Name & DM & FY-18 & FY-19 & FY-20 & FY-21 & FY-22 & FY-23 & Outyears & $\begin{array}{c}\text { Est. Total } \\
\text { Cost } \\
(\text { FY-18 \$) } \\
\end{array}$ \\
\hline 34 & FASB & $\begin{array}{l}\text { Development } \\
\text { glovebox } \\
\text { removal (DOE- } \\
\text { EM funded) }\end{array}$ & No & & $\$ 1,500$ & & & & & & $\$ 1,500$ \\
\hline 35 & $\begin{array}{c}\text { MFC- } \\
798\end{array}$ & $\begin{array}{l}\text { RLWTF D\&D } \\
\text { (DOE-EM } \\
\text { funded) }\end{array}$ & No & & $\$ 1,750$ & & & & & & $\$ 1,750$ \\
\hline 36 & $\mathrm{AL}$ & $\begin{array}{l}\text { ENU } \\
\text { Replacement }\end{array}$ & & & & $\$ 3,000$ & & & & & $\$ 3,000$ \\
\hline 37 & HFEF & $\begin{array}{l}\text { Exterior } \\
\text { roof/stack access } \\
\text { stairs }\end{array}$ & & & & $\$ 500$ & & & & & $\$ 500$ \\
\hline 39 & HFEF & $\begin{array}{l}\text { Argon } \\
\text { regenerations } \\
\text { valves } \\
\end{array}$ & & & & $\$ 500$ & & & & & $\$ 500$ \\
\hline 40 & RCL & $\begin{array}{l}\text { Convert heating } \\
\text { from steam to } \\
\text { electric }\end{array}$ & & & & $\$ 1,000$ & & & & & $\$ 1,000$ \\
\hline 41 & FCF & $\begin{array}{l}\text { Design, fab, and } \\
\text { install } \\
\text { feedthrough in } \\
\text { FCF to support } \\
\mathrm{CO}_{2} \text { cold jet } \\
\text { decon system }\end{array}$ & & & & $\$ 350$ & & & & & $\$ 350$ \\
\hline 42 & HFEF & $\begin{array}{l}\text { MET Box refurb } \\
\text { - purification } \\
\text { system } \\
\text { replacement }\end{array}$ & & & & $\$ 500$ & & & & & $\$ 500$ \\
\hline 43 & HFEF & $\begin{array}{l}\text { Containment } \\
\text { Box lid seal \& } \\
\text { hoist }\end{array}$ & No & & & $\$ 1,000$ & & & & & $\$ 1,000$ \\
\hline 44 & $\mathrm{FCF}$ & $\begin{array}{l}\text { MTG Revision } \\
\text { and user } \\
\text { interface update }\end{array}$ & No & & & $\$ 300$ & $\$ 300$ & $\$ 300$ & & & $\$ 900$ \\
\hline 45 & $\mathrm{AL}$ & $\begin{array}{l}\text { Ultra-Pure Water } \\
\text { Stations }\end{array}$ & No & & & & $\$ 240$ & & & & $\$ 240$ \\
\hline 46 & MFC & $\begin{array}{l}\text { Cask integration, } \\
\text { management, } \\
\text { and capability } \\
\text { sustainment }\end{array}$ & No & & & & $\$ 2,000$ & $\$ 3,500$ & & & $\$ 5,500$ \\
\hline $\begin{array}{c}\text { Not } \\
\text { Prioritized }\end{array}$ & All & $\begin{array}{l}\text { Fire barrier } \\
\text { refurbishment } \\
\text { across MFC } \\
\end{array}$ & No & & & & $\$ 1,500$ & & & & $\$ 1,500$ \\
\hline $\begin{array}{c}\text { Not } \\
\text { Prioritized }\end{array}$ & ZPPR & $\begin{array}{l}\text { ZPPR vault } \\
\text { cooling system } \\
\text { refurbishment }\end{array}$ & & & & & $\$ 500$ & & & & $\$ 500$ \\
\hline $\begin{array}{c}\text { Not } \\
\text { Prioritized }\end{array}$ & $\begin{array}{c}\text { MFC- } \\
768\end{array}$ & $\begin{array}{l}\text { MFC Power } \\
\text { Plant Conversion } \\
\text { (mock up, labs, } \\
\text { offices) }\end{array}$ & No & & & & & & & $\$ 3,000$ & $\$ 3,000$ \\
\hline $\begin{array}{c}\text { Not } \\
\text { Prioritized }\end{array}$ & $\begin{array}{c}\text { MFC- } \\
798\end{array}$ & $\begin{array}{l}\text { Former RLWTF } \\
\text { facility } \\
\text { conversion }\end{array}$ & No & & & & & & & & TBD \\
\hline $\begin{array}{c}\text { Not } \\
\text { Prioritized }\end{array}$ & Sitewide & $\begin{array}{l}\text { Computed } \\
\text { Tomography for } \\
\text { QA }\end{array}$ & No & & & & $\$ 750$ & & & & $\$ 750$ \\
\hline
\end{tabular}




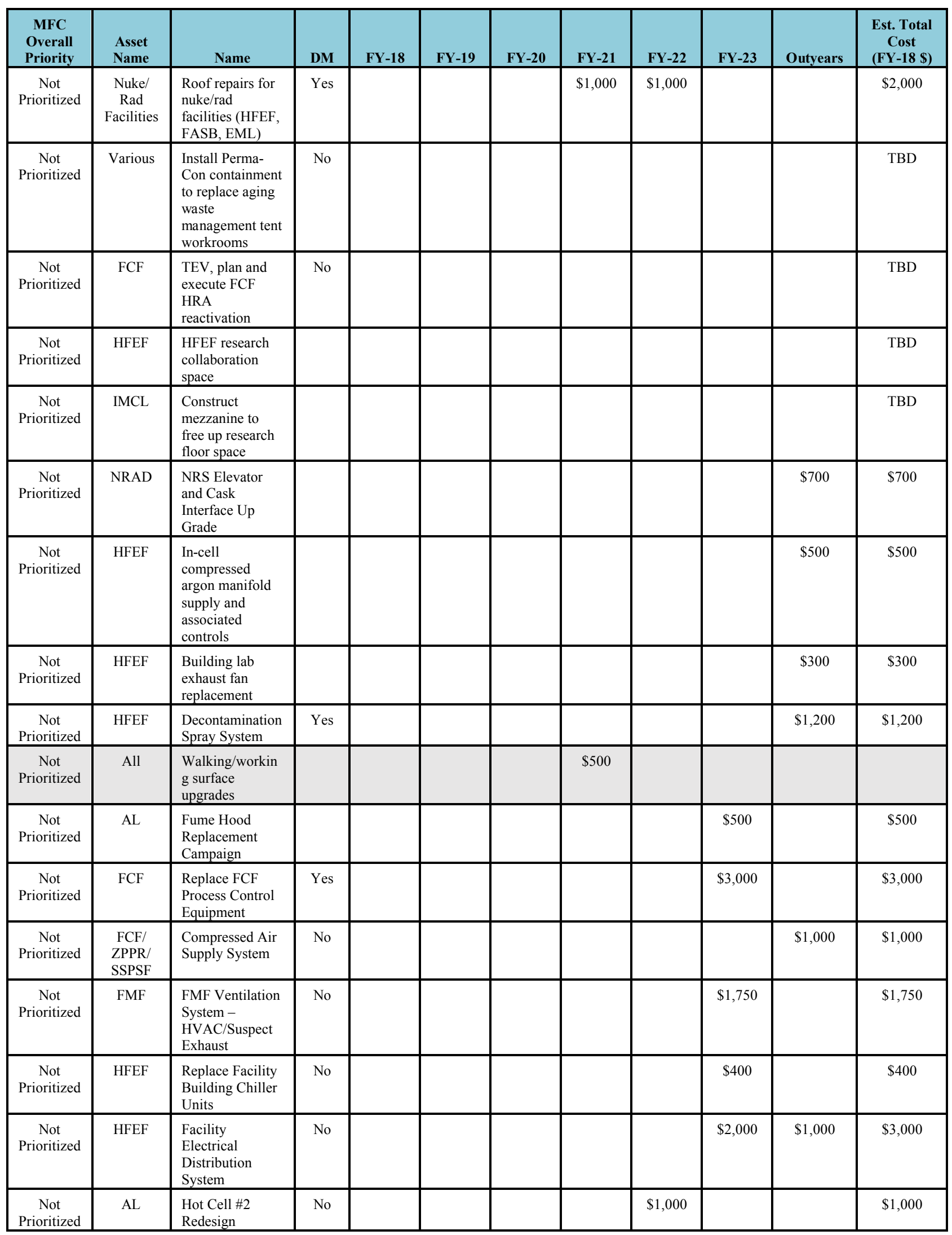




\begin{tabular}{|c|c|c|c|c|c|c|c|c|c|c|c|}
\hline $\begin{array}{l}\text { MFC } \\
\text { Overall } \\
\text { Priority } \\
\end{array}$ & $\begin{array}{l}\text { Asset } \\
\text { Name } \\
\end{array}$ & Name & DM & FY-18 & FY-19 & FY-20 & FY-21 & FY-22 & FY-23 & Outyears & $\begin{array}{c}\text { Est. Total } \\
\text { Cost } \\
(\text { FY-18 \$) }\end{array}$ \\
\hline $\begin{array}{c}\text { Not } \\
\text { Prioritized }\end{array}$ & HFEF & $\begin{array}{l}\text { Pneumatic } \\
\text { Sample Transfer } \\
\text { Control System } \\
\text { Upgrades }\end{array}$ & No & & & & & & $\$ 275$ & & $\$ 275$ \\
\hline $\begin{array}{c}\text { Not } \\
\text { Prioritized }\end{array}$ & FASB & $\begin{array}{l}\text { Upgrade FASB } \\
\text { Ventilation } \\
\text { System } \\
\end{array}$ & No & & & & & $\$ 500$ & $\$ 500$ & & $\$ 1,000$ \\
\hline $\begin{array}{c}\text { Not } \\
\text { Prioritized }\end{array}$ & ZPPR & $\begin{array}{l}\text { U processing } \\
\text { glovebox in } \\
\text { ZPPR } \\
\text { Workroom } \\
\end{array}$ & No & & & & & & & $\$ 3,500$ & $\$ 3,500$ \\
\hline $\begin{array}{c}\text { Not } \\
\text { Prioritized } \\
\end{array}$ & FMF & $\begin{array}{l}\text { PU Stabilization } \\
\text { Glovebox }\end{array}$ & No & & & & $\$ 500$ & $\$ 2,500$ & $\$ 1,500$ & & $\$ 4,500$ \\
\hline $\begin{array}{c}\text { Not } \\
\text { Prioritized }\end{array}$ & $\begin{array}{l}\mathrm{HFEF} / \\
\mathrm{FCF} / \\
\mathrm{EBR}-\mathrm{II}\end{array}$ & $\begin{array}{l}480 \text { V Critical } \\
\text { Switchgear } \\
\text { Replacements }\end{array}$ & No & & & & & & $\$ 2,000$ & $\$ 1,000$ & $\$ 3,000$ \\
\hline $\begin{array}{c}\text { Not } \\
\text { Prioritized }\end{array}$ & FCF & $\begin{array}{l}\text { In-cell Periscope } \\
\text { and Camera } \\
\text { System }\end{array}$ & No & & & & & $\$ 925$ & & & $\$ 925$ \\
\hline $\begin{array}{c}\text { Not } \\
\text { Prioritized }\end{array}$ & $\mathrm{AL}$ & $\begin{array}{l}\text { AL Hot Cell } \\
\text { Lighting } \\
\text { Upgrade }\end{array}$ & No & & & & & & & $\$ 1,500$ & $\$ 1,500$ \\
\hline $\begin{array}{c}\text { Not } \\
\text { Prioritized }\end{array}$ & $\mathrm{AL}$ & $\begin{array}{l}\text { Rabbit Xfer from } \\
\text { HC to B-wing }\end{array}$ & No & & & & & & & $\$ 1,500$ & $\$ 1,500$ \\
\hline \multirow[t]{3}{*}{$\begin{array}{c}\text { Not } \\
\text { Prioritized } \\
\end{array}$} & $\mathrm{AL} / \mathrm{RCL}$ & $\begin{array}{l}\text { RCL Backup } \\
\text { Power }\end{array}$ & No & & & & & & & $\$ 450$ & $\$ 450$ \\
\hline & & TOTALS & & $\$ 41,100$ & $\$ 31,410$ & $\$ 20,250$ & $\$ 18,990$ & $\$ 18,895$ & $\$ 18,925$ & $\$ 15,650$ & $\$ 163,520$ \\
\hline & & $\begin{array}{l}\text { Less Lab } \\
\text { Investments/EM } \\
\text { (NE Funding } \\
\text { Only) } \\
\end{array}$ & & $\$ 41,100$ & $\$ 21,850$ & $\$ 18,850$ & $\$ 18,090$ & $\$ 18,495$ & $\$ 18,525$ & $\$ 15,650$ & $\$ 157,420$ \\
\hline \multicolumn{3}{|c|}{$\begin{array}{l}\text { Potential to seek indirect lab investments or } \\
\text { other program funding. It is not anticipated } \\
\text { that IFM will fund these items. }\end{array}$} & \multicolumn{5}{|c|}{$\begin{array}{l}\text { Green shaded rows represent scope } \\
\text { authorized to proceed }\end{array}$} & \multicolumn{4}{|c|}{$\begin{array}{l}\text { Note: These are conceptual cost estimates } \\
\text { and will change as planning matures }\end{array}$} \\
\hline
\end{tabular}




\subsection{Waste and Materials Management}

\subsubsection{Newly Generated Waste Management}

MFC manages various newly generated and legacy research related materials and wastes as part of their environmental stewardship responsibility and compliance with DOE O 435 requirements. Detailed treatment and disposition paths as well as alternative disposition paths being evaluated have been established.

All newly generated waste is managed under an INL service center full cost-recovery program that ensures waste costs are paid for by the generating programs or facilities and funding is available in the future for disposition of all waste types. The INL Waste Management Program (WMP) administers two site-wide service centers. The INL Waste Generator Services service center collects revenue and pays disposition costs for waste with a readily available disposition path and establishes disposition paths for new waste streams prior to generation. The INL remote-handled (RH) Waste Service Center collects revenue for newly generated RH waste that will be dispositioned when the INL RH-low-level waste (LLW) Disposal Facility opens or when the backlog at WIPP is eliminated after reopening.

Currently BEA is using the EM ID Idaho Cleanup Contract contractor capabilities and Waste Isolation Pilot Plant (WIPP) certified Transuranic (TRU) program certification for disposition of contacthandled $(\mathrm{CH})$ and RH-TRU. The current version of the 5-year plan assumes this pathway exists thru May 2021. In light of the recent DOE EM decision to close the Advanced Mixed Waste Treatment Project (AMWTP) at end of 2019, BEA is developing a plan to establish a TRU program to support ongoing newly generated TRU. This plan will address increased waste generation due to new and emerging programs such as the Versatile Test Reactor (VTR) and high assay low enriched uranium (HALEU) programs, assess what is needed to support waste certification and characterization, and investigate siting options for this capability. AMWTP provides critical characterization, certification, and transportation support for BEA generated CH-TRU waste. A major capability of AMWTP facilities is waste conditioning and waste repackaging. This capability will not be needed for BEA generated CH-TRU waste. BEA's TRU programing planning will assess the capabilities of the AMWTP facilities and make recommendations regarding retention of characterization and certification equipment and siting of this capability for future program support. For example, co-locating this CH-TRU capability with RH-TRU capability at INTEC may have significant benefit. In addition to this TRU program planning activity, BEA is also taking leadership in the formulation of a Battelle community of practice specifically addressing TRU waste disposition as analogous situation exists at other Battelle managed National Laboratories. 


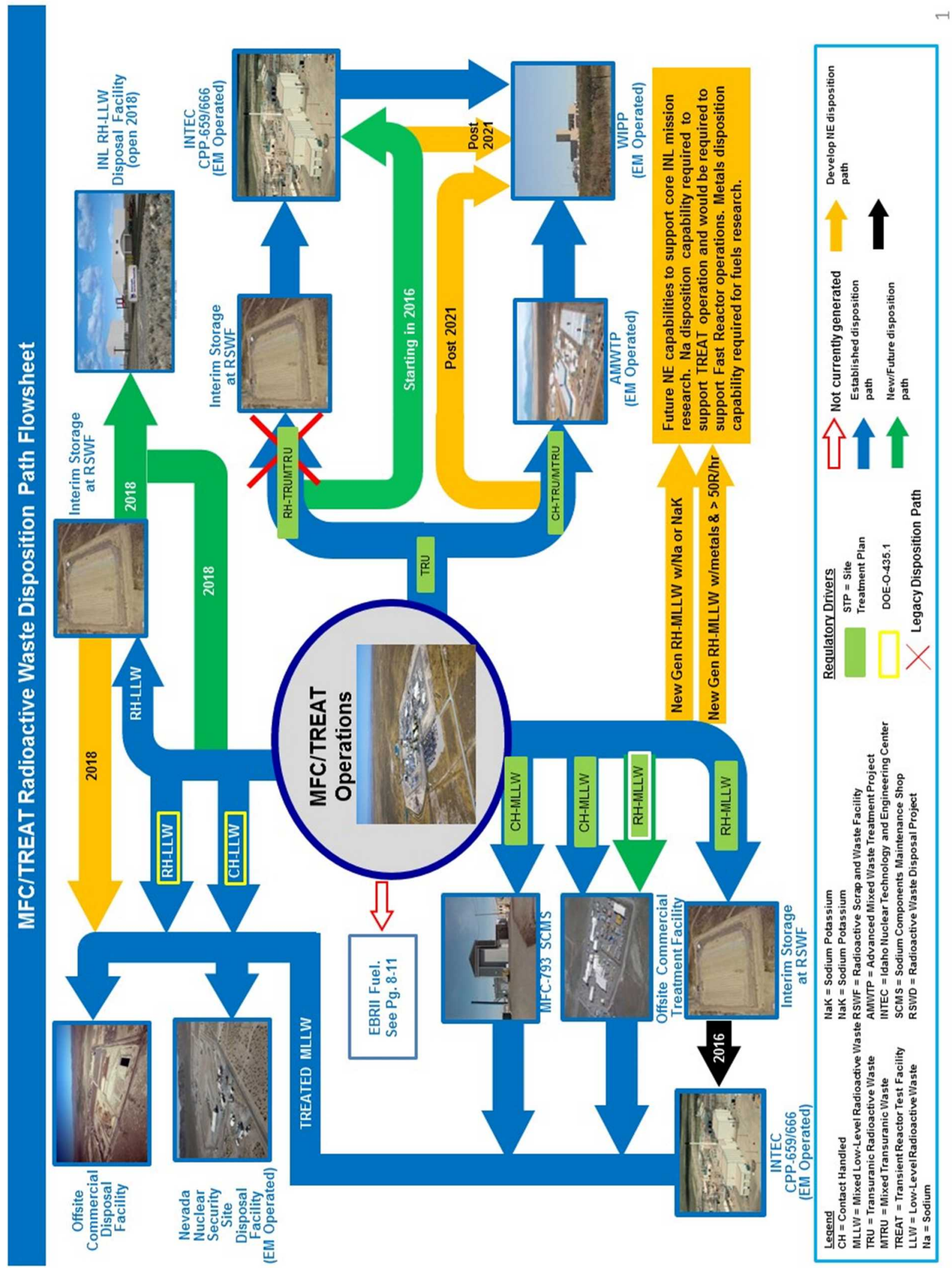

Figure 3. MFC/TREAT Radioactive Waste Disposition Path Flowsheet. 


\subsubsection{Legacy Materials Management}

The Department of Energy (DOE) is responsible for the storage, management, and disposition of a number of legacy waste inventories including irradiated sodium-bonded uranium-based material from the EBR-II reactor, sodium-contaminated $\mathrm{CH}$ and RH mixed transuranic waste (MTRU), RH mixed low-level waste (MLLW), and CH-MLLW. These items are all managed under the INL Site Treatment Plan (STP) as directed by the consent order between the DOE and the Idaho Department of Environmental Quality (IDEQ).

A strategic plan has been developed for establishing a path for off-site treatment capabilities for the CH-MLLW, and portions of the RWDP backlog, with the potential for application of the treatment capability against future reactive waste or materials on a case-by-case basis. In conjunction with establishing viable off-site treatment capabilities, BEA, using EM funding, is executing a proof of concept demonstration with the objective of developing and demonstrating a prototype system to improve the RWDP liner retrieval process. This prototype system will be designed to provide a sized reduced liner thereby improving the efficiency of down-stream waste handling and processing/disposition. The proof of concept demonstration will include a coupled demonstration of the advanced liner retrieval system and new off-site treatment options. It is anticipated that this alternative RWDP liner disposition approach will significantly reduce cost and schedule associated with the INL Site Treatment Plan.

Identifying off-site treatment as the preferred approach considered several factors, including how quickly the respective inventories could be dispositioned, realizing efficiencies by focusing on more than one off-site treatment provider, total lifecycle cost savings, and INL capabilities associated with disposition that should be retained, expanded, or retired with respect to the enduring mission of the INL. This plan also provides the key activities, preliminary cost estimates, and high level schedule that are required to implement the preferred approach. MFC has taken action to integrate with the VTR program to ensure that off-site and on-site capabilities exist to manage waste and SNF, in compliance with INL regulatory drivers, generated by planned VTR activities.

MFC is also in the process of repackaging legacy RH-TRU/MTRU waste located in the HFEF and FCF Hot Cells in a manner compatible with characterization capabilities located at INTEC CPP-659 (e.g., externally clean 55-gallon drums). Characterization using Real-Time Radiography and Non-destructive Assay techniques will be used in INTEC CPP-659 to certify the waste containers prior to shipment to WIPP.

Legacy reactive materials associated with the ZPPR Storage Area are currently managed as assets in support of research and development because they are highly engineered materials with potential application in future research across the DOE Complex. As new projects are identified in support of expanding MFC's research capabilities it may be necessary to repurpose the space where these materials are stored. Should it be determined that the remaining material or a portion of the remaining material is no longer expected to serve a useful purpose then they will have to be treated (to remove the reactivity) prior to being dispositioned.

The funding profile associated with the various inventories is outlined in Table 3 below which summarizes the investments for treating the irradiated EBR-II elements, as well as, waste and materials management from multiple fund sources across the laboratory. 
Table 3. MFC Materials and Waste Management Funding Profile.

\begin{tabular}{|l|c|c|c|c|c|c|}
\hline \multicolumn{1}{|c|}{ Activity } & $\mathbf{2 0 1 9}$ & $\mathbf{2 0 2 0}$ & $\mathbf{2 0 2 1}$ & $\mathbf{2 0 2 2}$ & $\mathbf{2 0 2 3}$ & Total (K) \\
\hline Driver Fuel Treatment & $\$ 7,988$ & $\$ 8,228$ & $\$ 8,474$ & $\$ 8,728$ & $\$ 8,991$ & $\mathbf{\$ 4 2 , 4 0 9}$ \\
\hline HALEU Production & $\$ 5,600$ & $\$ 6,800$ & $\$ 7,000$ & $\$ 7,200$ & $\$ 7,400$ & $\mathbf{\$ 3 4 , 0 0 0}$ \\
\hline $\begin{array}{l}\text { R\&D for treatment alternatives } \\
\text { \& efficiency improvements }\end{array}$ & & $\$ 1,645$ & $\$ 1,685$ & $\$ 1,730$ & $\$ 1,775$ & $\mathbf{\$ 6 , 8 3 5}$ \\
\hline SCMS backlog (STP) & $\$ 1,000$ & $\$ 1,500$ & $\$ 3,000$ & $\$ 3,000$ & $\$ 3,000$ & $\mathbf{\$ 1 1 , 5 0 0}$ \\
\hline $\begin{array}{l}\text { CH MLLW Treatment } \\
\text { Alternatives }\end{array}$ & $\$ 405$ & $\$ 1,500$ & $\$ 1,500$ & $\$ 1,500$ & $\$ 1,500$ & $\mathbf{\$ 6 , 4 0 5}$ \\
\hline $\begin{array}{l}\text { RH TRU/MTRU Repack } \\
\text { (Part of 5YP Legacy Matl. } \\
\text { Disposition) }\end{array}$ & $\$ 500$ & $\$ 500$ & $\$ 500$ & $\$ 500$ & $\$ 500$ & $\mathbf{\$ 2 , 5 0 0}$ \\
\hline $\begin{array}{l}\text { RWDP Backlog -RH MLLW } \\
\text { retrievals (DOE-EM funded) }\end{array}$ & $\$ 700$ & $\$ 700$ & & & & \\
\hline $\begin{array}{l}\text { RWDP Backlog - Proof of } \\
\text { Concept Demonstration for RH } \\
\text { MLLW Advanced Retrievals } \\
\text { (DOE-EM funded) }\end{array}$ & $\$ 10,000$ & $\mathrm{TBD}$ & $\mathrm{TBD}$ & $\mathrm{TBD}$ & $\mathrm{TBD}$ & $\mathbf{\$ 1 0 , 0 0 0}$ \\
\hline $\begin{array}{l}\text { RWDP Backlog (DOE-NE } \\
\text { funded) }\end{array}$ & $\mathrm{N} / \mathrm{A}$ & $\$ 1,500$ & $\$ 9,500$ & $\$ 3,000$ & $\mathrm{TBD}$ & $\mathbf{\$ 1 4 , 0 0 0}$ \\
\hline $\begin{array}{l}\text { ZPPR Reactive Material } \\
\text { Disposition (Laboratory funded) }\end{array}$ & $\mathbf{\$ 2 , 0 0 0}$ & $\mathbf{\$ 2 , 0 0 0}$ & $\mathbf{\$ 2 , 0 0 0}$ & & & \\
\hline Total DOE-NE Funding & $\mathbf{\$ 1 5 , 4 9 3}$ & $\mathbf{\$ 2 0 , 1 7 3}$ & $\mathbf{\$ 2 2 , 1 5 9}$ & $\mathbf{\$ 2 2 , 6 5 8}$ & $\mathbf{\$ 2 3 , 1 6 6}$ & $\mathbf{\$ 1 0 3 , 6 4 9}$ \\
\hline Total Laboratory Funding & $\mathbf{\$ 2 , 0 0 0}$ & $\mathbf{\$ 2 , 0 0 0}$ & $\mathbf{\$ 2 , 0 0 0}$ & $\mathbf{\$}-$ & $\mathbf{\$}-$ & $\mathbf{\$ 6 , 0 0 0}$ \\
\hline Total DOE-EM Funding & $\mathbf{\$ 1 0 , 7 0 0}$ & $\mathbf{\$ 7 0 0}$ & $\mathbf{T B D}$ & $\mathbf{T B D}$ & & $\mathbf{\$ 1 1 , 4 0 0}$ \\
\hline Total (K) & $\mathbf{\$ 2 8 , 1 9 3}$ & $\mathbf{\$ 2 2 , 8 7 3}$ & $\mathbf{\$ 2 4 , 1 5 9}$ & $\mathbf{\$ 2 2 , 6 5 8}$ & $\mathbf{\$ 2 3 , 1 6 6}$ & $\mathbf{\$ 1 2 1 , 0 4 9}$ \\
\hline
\end{tabular}

\subsubsection{Strategy to Accelerate Production of High Assay Low-Enriched Uranium (HA-LEU) Material}

The irradiated sodium-bonded uranium-based material from the EBR-II reactor includes $\sim 60$ metric tons of heavy metal. Due to the reactive nature of the sodium component of this material, it is not a candidate for direct geologic disposal under current DOE policy, unless the reactive hazard is mitigated. Consequently, the material has been consolidated and placed into interim storage at INL for evaluation and processing.

The current processing method is the electrometallurgical treatment (EMT) process for treatment of both the highly enriched uranium driver fuel and depleted uranium based blanket elements irradiated in EBR-II. The technology has been demonstrated to be effective at simultaneously separating the components of the used fuel and neutralizing the bond sodium; however, improvements for efficiency and/or alternative processing technologies will be necessary to successfully meet the 2035 deadline agreed to in the Idaho Settlement Agreement (ISA). Accordingly, INL has initiated investigations aimed at identifying potential management alternatives, as well as possible process enhancements to the current system. The goal of the investigation is to identify new technologies/methods for efficiency improvements and cost reductions in order to successfully achieve the 2035 ISA deadline.

FCF is currently operated 4 days/week, 10 hours/day under current funding of approximately $\$ 8 \mathrm{M}$. The current funding includes support for 25 FTEs and a production rate of 6 batches of driver fuel processed per year. FCF is transitioning to a $7 \mathrm{~d} / 12 \mathrm{~h}$ work schedule in FY-19 to support additional production rates and to produce a HALEU product that may be used as a fuel feedstock that is capable of 
supporting advanced reactor designs. This initial ramp-up is estimated at $\$ 5.6 \mathrm{M}$ additional funding for FY-19 with full year annual escalation thereafter (see Table 3).

The age of the facility and processing equipment, coupled with the harsh operating environment and unique material handling needs associated with the existing batch process, introduces risks to sustained high throughput operations. To mitigate these risks, refurbishment of the through-wall tele-manipulators and overhead electro-mechanical manipulators is currently being executed as part of the MFC plant health investments (see Table 2, item 4 \& 14). Additional plant health investment will fund process improvements including installation of a new, redundant cathode processor (multi-function furnace), a new remotely operated work station to consolidate bottle inspection and wire removal, and a new scraped cathode module for use in the electrorefiners. These investments will help to eliminate existing single point failures and increase operating efficiencies for the existing processing equipment.

\subsubsection{Funding and Schedule Estimate to Achieve Desired Production Rate}

The incremental acceleration and utilization of legacy inventory scenario assumes a production schedule of 7 days/week, 12 hours/day and assumes 6 treatment batches in the MK-IV electrorefiner and 20 ingots recast from the legacy recovered uranium inventory.

The strategy is summarized as follows:

- Continue processing EBR-II SNF at the current rate, complete processing improvements, including introduction of improved product form ( $\sim 3 \mathrm{~kg}$ ingots) and adding a new processing furnace to supplement the current cathode processor ( fall of 2021)

- Integrate "recasting" or isotopic cleanup of legacy product inventory using process enhancements to produce a smaller, lower dose product beginning in 2019

- Working schedule in FCF is increased to 7 days/week, 12 hours/day

- Required funds escalated at 3\%/yr 2019-2023, funding requirements will increase in 2024 for additional cost of retrieving EBR-II driver fuel from RSWF

- All legacy inventory is recast by 2023. All Driver Fuel treatment complete by June 2028

- Treated product inventory will reach 5MT in 2020 and consist of legacy 4MT inventory + 1MT newly treated

- $5 \mathrm{MT}$ of potential HALEU feedstock available by December 2023.

Table 4. Proposed Schedule for Accelerated HALEU Production.

\begin{tabular}{|l|c|c|c|c|c|}
\hline \multicolumn{6}{|c|}{ Estimated Accelerated HALEU Production from FCF } \\
\hline & \multicolumn{5}{|c|}{ Direct Ship from CPP-666 to FCF } \\
\hline & 2019 & 2020 & 2021 & 2022 & 2023 \\
\hline HALEU from Base SNF Ops & .245 & .245 & .245 & .245 & .245 \\
\hline HALEU from Recast Ops & .400 & 0.800 & .800 & .800 & .800 \\
\hline Total HALEU & .645 & 1.045 & 1.045 & 1.045 & 1.045 \\
\hline & \multicolumn{7}{|c|}{ Total from EBR-II Driver (MT) } \\
\hline
\end{tabular}




\subsection{Deferred Maintenance Listing}

Table 5 below is the current full list of deferred maintenance as of September 2017 for MFC. Deferred maintenance addressed as part of the plant health initiative is identified in Table 2.

Table 5. MFC DM Master List as of September 2017.

\begin{tabular}{|c|c|c|c|}
\hline ID & Requirement - Asset Name & Requirement Name & Est. Cost (\$) \\
\hline CPP-1674 & CPP-1674 - Central Alarm Station & Repair Old security gate & $\$ 48,065$ \\
\hline СРP-651 & $\begin{array}{l}\text { CPP-651 - Mat'l Security \& Consolidation } \\
\text { Fac. }\end{array}$ & Vault Berm & $\$ 534,061$ \\
\hline MFC-701 & MFC-701 - Security Building & Deteriorated Raised Floor Tiles & $\$ 34,213$ \\
\hline MFC-701 & MFC-701 - Security Building & Replace Exterior Windows & $\$ 31,970$ \\
\hline MFC-701 & MFC-701 - Security Building & Deteriorated Vinyl Composition Tile & $\$ 5,730$ \\
\hline MFC-704 & MFC-704 - Fuel Manufacturing Facility & Replace Roof Section RF02 & $\$ 1,525,641$ \\
\hline MFC-704 & MFC-704 - Fuel Manufacturing Facility & Replace Roof Section RF01 & $\$ 174,359$ \\
\hline MFC-725 & MFC-725 - MFC Fire Station & Repair Leaking Windows & $\$ 262,005$ \\
\hline MFC-752 & MFC-752 - Lab \& Office Bldg. & Refurbish Leaking Window in Hot Cell 5 & $\$ 427,249$ \\
\hline MFC-752 & MFC-752 - Lab \& Office Bldg. & Refurbish Leaking Window in Hot Cell 6 & $\$ 427,249$ \\
\hline MFC-765 & MFC-765 - Fuel Conditioning Facility & Replace Hot Cell Windows "A1" & $\$ 2,281,316$ \\
\hline MFC-765 & MFC-765 - Fuel Conditioning Facility & $\begin{array}{l}\text { Plant air compressor has exceeded } \\
\text { expected lifetime. }\end{array}$ & $\$ 373,843$ \\
\hline MFC-765 & MFC-765 - Fuel Conditioning Facility & $\begin{array}{l}\text { Bldg. } 765 \text { electrical switchgear is past } \\
\text { EOL. Parts are difficult to obtain. }\end{array}$ & $\$ 2,136,244$ \\
\hline MFC-765 & MFC-765 - Fuel Conditioning Facility & Corroded Metal Doors & $\$ 17,546$ \\
\hline MFC-765 & MFC-765 - Fuel Conditioning Facility & $\begin{array}{l}\text { Deteriorated Vinyl Composition Tile } \\
\text { (VCT) }\end{array}$ & $\$ 27,309$ \\
\hline MFC-765A & MFC-765A - FCF Office Annex & $\begin{array}{l}\text { Deteriorated Vinyl Composition Tile } \\
\text { (VCT) Flooring }\end{array}$ & $\$ 15,898$ \\
\hline MFC-768 & MFC-768 - Power Plant & Cooling water system & $\$ 1,708,995$ \\
\hline MFC-768 & MFC-768 - Power Plant & Replace Roof Section RF02 & $\$ 127,192$ \\
\hline MFC-768 & MFC-768 - Power Plant & Deteriorated Exterior Windows & $\$ 81,717$ \\
\hline MFC-768 & MFC-768 - Power Plant & Water Intrusion in Cable Tunnel & $\$ 28,425$ \\
\hline MFC-768 & MFC-768 - Power Plant & Damaged Concrete Block Wall & $\$ 85,620$ \\
\hline MFC-771 & $\begin{array}{l}\text { MFC-771 - Radioactive Scrap and Waste } \\
\text { Facility }\end{array}$ & Cathodic protection EOL. & $\$ 1,335,153$ \\
\hline MFC-781 & MFC-781 - Materials Handling Bldg & $\begin{array}{l}\text { Corroded Loading Dock Equipment } \\
\text { (North) }\end{array}$ & $\$ 28,256$ \\
\hline MFC-785 & MFC-785 - Hot Fuel Examination Facility & Facility evaporated Air Supply & TBD \\
\hline MFC-785 & MFC-785 - Hot Fuel Examination Facility & $\begin{array}{l}\text { Refurbish Leaking Hot Cell Window - } \\
20 \mathrm{M}\end{array}$ & $\$ 1,525,888$ \\
\hline MFC-785 & MFC-785 - Hot Fuel Examination Facility & Refurbish Leaking Hot Cell Window - 5M & $\$ 1,525,888$ \\
\hline MFC-785 & MFC-785 - Hot Fuel Examination Facility & Refurbish Leaking Hot Cell Window - 6M & $\$ 1,525,888$ \\
\hline MFC-785 & MFC-785 - Hot Fuel Examination Facility & Refurbish Leaking Hot Cell Window - 4D & $\$ 1,525,888$ \\
\hline
\end{tabular}




\begin{tabular}{|c|c|c|c|}
\hline ID & Requirement - Asset Name & Requirement Name & Est. Cost (\$) \\
\hline MFC-785 & MFC-785 - Hot Fuel Examination Facility & $\begin{array}{l}\text { Correct deteriorated exterior walls, leaking } \\
\text { foundation wall, and sealed flooring. }\end{array}$ & $\$ 469,703$ \\
\hline MFC-785 & MFC-785 - Hot Fuel Examination Facility & Facility Out-of-cell cranes 40 ton high bay & $\$ 1,602,183$ \\
\hline MFC-785 & MFC-785 - Hot Fuel Examination Facility & Argon compressors & $\$ 1,335,153$ \\
\hline MFC-785 & MFC-785 - Hot Fuel Examination Facility & Main cell purification blowers & $\$ 801,092$ \\
\hline MFC-785 & MFC-785 - Hot Fuel Examination Facility & Small transfer lock doors and structure & $\$ 368,731$ \\
\hline MFC-785 & MFC-785 - Hot Fuel Examination Facility & Decon spray system & $\$ 157,966$ \\
\hline MFC-785 & MFC-785 - Hot Fuel Examination Facility & Facility water and steam heating system & $\$ 752,076$ \\
\hline MFC-785 & MFC-785 - Hot Fuel Examination Facility & NRS Exhaust & $\$ 373,843$ \\
\hline MFC-785 & MFC-785 - Hot Fuel Examination Facility & Air Conditioning Ducts & $\$ 7,358$ \\
\hline MFC-790 & MFC-790 - Equipment Storage & Replace Deteriorated Roof Insulation & $\$ 437$ \\
\hline MFC-791 & $\begin{array}{l}\text { MFC-791 - Instrument \& Maintenance } \\
\text { Facility }\end{array}$ & Deteriorated Concrete Block Walls & $\$ 70,230$ \\
\hline MFC-794 & MFC-794 - Experimental Fuels Facility & Replace Damaged Steel Beam & $\$ 1,934$ \\
\hline \multirow[t]{2}{*}{ MFC-798 } & $\begin{array}{l}\text { MFC-798 - Radioactive Liquid Waste } \\
\text { Treatment Facility }\end{array}$ & MFC-798 holding tanks leak & $\$ 1,602,183$ \\
\hline & & Total & $\$ 25,364,497$ \\
\hline
\end{tabular}




\section{INSTRUMENT SCIENTISTS AND NEW INSTRUMENT CAPABILITIES}

Experiment infrastructure supports dedicated instrument science teams and a funding line for new instrumentation that, when coupled together, push the boundaries of nuclear energy research. Dedicated predictable funding is required to ensure this capability is available to accept current mission work and provide the ability to fully support the growing industry need for research.

\subsection{Instrument Science Teams}

A dedicated cadre of scientists, engineers, and technicians is critical to enable efficient generation of high-quality information that moves innovative concepts up the scale of technology readiness. Instrument scientists and engineers are responsible for:

- Ensuring that each research tool is performing at its peak level and seeking world leading innovations in data analysis and instrument hardware

- Performing great science as part of collaborative teams and serving the user community as a subject matter expert on instrument techniques and data analysis

- Helping build the user community by seeking opportunities to apply instrument techniques in unique and innovative ways to materials and fuels challenges.

These scientists, engineers, and technicians require a specialized skill set to operate sophisticated research instruments, interpret data, and safely and effectively conduct research in nuclear facilities. Instrument science teams publish extensively to ensure dissemination of knowledge gained from their instrument.

These skills are acquired and honed by training and experience over several years. As MFC research facilities extend capabilities and operating hours to deliver on increasing requests for research, additional instrument scientists and support staff will be required. In order to be effective in helping drive innovation, these staff must be able to focus in a manner that allows them to be world-leading experts. MFC is experiencing a steady increase in research requests that have exceeded the existing staff's ability to support. A user facility-like model for developing personnel must be cultivated that allows both hiring in advance of the need and more efficiently and effectively increasing, introducing, and reinforcing the core principals and critical skills required to build competence.

Part of the instrument science function (great science) is currently supported by DOE programs; however, these programs are focused on fuels and materials. Stable funding for instrument scientists allows focus on instruments, measurement techniques, and analysis methods enabling existing characterization and post-irradiation examination instruments to meet user needs and provide world-class data.

A wide range of instruments and techniques are required to execute the nuclear technology development cycle, including skill sets that are not typically represented at instrument-focused user facilities. Fabrication material scientists, for example, provide fuel and material specimens that are a necessary part of the development cycle.

Proposed instrument scientist teams include the following instrument and technique areas:

- Nuclear fuel fabrication research

- Nuclear fuel and cladding system assembly

- Visual examination

- Neutron and x-ray radiographic and tomographic imaging 
- Gamma spectrometry

- Eddy current analysis

- Metrology (the science of dimensional measurement)

- Fission gas measurement and analysis

- Optical microscopy (including sample preparation and micro-hardness testing)

- Mechanical property testing

- Fuel accident testing

- Thermal property measurement

- Scanning Electron Microscopy (SEM)

- Electron Probe Micro-Analysis (EPMA)

- $\quad$ Focused Ion Beam (FIB)

- Transmission Electron Microscopy (TEM)

- Neutron and x-ray diffraction

- Analytical chemistry sample preparation

- Inductively Coupled Plasma (ICP) Methods (Atomic Emission Spectroscopy, Mass Spectroscopy, Multi-Collector)

- Thermal Ion Mass Spectroscopy (TIMS)

- Gas Mass Spectroscopy

- Radiochemistry

- Alpha Spectroscopy

- Beta Spectroscopy

- Gamma Spectroscopy

- Wet chemical separations

- Data analysis and visualization

- Statistical analysis of data.

Instrument science teams consist of lead instrument scientists, engineers, and technical specialists. Program funding currently supports existing team members. Additional staffing needs will increase with increased scientific capabilities, additional responsibilities of instrument scientists, and the increasing MFC research workload.

The funding profile provided in Table 6 is proposed to transition to the instrument scientist funding approach described in Section 1.3 to accelerate development and implementation of state-of-the-art instruments and capabilities that are essential for MFC's function as a national nuclear R\&D test bed. This includes the additional scientists needed to support emerging capabilities associated with growth of the NE test bed such as emerging capabilities in the IMCL and future capabilities in SPL. 


\subsection{Scientific Instrument Development Strategy}

Many advanced nuclear technologies require new materials and fuels. Efficient development of materials and fuels is enhanced by understanding starting at the atomic scale, the scale at which radiation damage occurs. Understanding, at this scale, reduces the number of trial and error experiment cycles required for development. The spectacular scientific and engineering achievements of the last century have followed the same method of transition from basic research to applied science and then to engineering applications, heavily reliant on understanding through instrumentation and testing at each stage of research and development.

Cutting-edge instruments make the production of knowledge more efficient; they enable us to understand physical phenomena with more precision and speed. The development and application of new instruments enables researcher and development teams to ask and to answer increasingly complex questions.

Instrumentation specific to nuclear fuels and materials science is not widely available. Of the hundreds of scanning electron microscopes in the United States, a relative few are available for use on radiological materials. Those instruments that are available for use on radiological materials are almost universally limited to materials with low activity. These materials have cooled for long times, have not been exposed to high neutron fluence, or have not been irradiated in a prototypic neutron environment, and are often of limited relevance. Rapid, routine, and efficient analysis of high dose-rate fuels and materials using state-of-the-art instrumentation is required if nuclear technology is to advance at a rate similar to other energy technology sectors.

Instruments that enable rapid, routine, and efficient analysis shorten that nuclear development cycle, increase the chance for breakthroughs, and lower the cost of development. Because development of advanced nuclear fuels and materials cannot occur without the capability to fabricate nuclear samples, fabrication capability is included in the MFC instrumentation strategy.

Planned investment in instrumentation at MFC will focus on making nuclear-capable instruments widely available to the research community. The strategy presented here is based upon current known program needs and current instrument capabilities, and will evolve with increasing engagement of industry and academia. Continuous improvement in instrumentation and data analysis methods, driven by user needs, is a key component of this strategy.

\subsubsection{MFC Research Instrumentation Strategy}

Use of instruments at MFC is rapidly trending upward as new capabilities are installed and new characterization techniques are assimilated by the user community. Current operating FIB, SEM, and EPMA instruments now have a backlog of 3-9 months. The availability of high resolution TEM and shielded FIB, SEM, and EPMA capability has resulted in a further increase in use.

Replacement or upgrade of instrumentation on a regular basis is required. Major improvements in instrumentation occur approximately on a 3-5 year cycle. Most instrumentation becomes technologically obsolete after 8-10 years. After 10-15 years of service, replacement parts become difficult to find, and vendors may stop supporting service contracts. Replacement of instruments on an 8-10 year cycle ensures that a subset of instruments provide state-of-the-art capabilities to the nuclear research community at all times.

Examples of instrumentation needs (and 2019 updates) from 2019 - 2023 include:

- High spatial resolution thermal conductivity measurement system to measure the change in thermal conductivity across a fuel pellet.

- High-resolution multi-collector inductively coupled mass spectrometers that provide extremely accurate isotopic analysis in a fraction of the time of previous technology. This is needed for improved fuel burnup analyses and fission product measurements. (One has been purchased for AL.) 
- A second shielded cell for performing irradiation assisted stress corrosion cracking (IASCC) growth rate measurements.

- Femto-second laser that allows rapid and quantitative chemical and isotopic analysis of nuclear materials without chemical dissolution.

- Neutron diffraction that provides information critical to understanding the internal crystallographic structure of fuels and materials.

- Advanced manufacturing fuel fabrication capability that enables fuel RD\&D programs that are critical to the development of many advanced reactor concepts. (Several items have been ordered and are in production)

- An advanced non-destructive post-irradiation examination system that greatly reduces the time required for a complete examination while providing higher quality data than current methods.

- Digital neutron tomography in development that will allow routine three-dimensional imaging of fuels and materials.

- Small cask systems that allow efficient transfer of high activity material specimens on-site, nationally, and internationally.

- Gloveboxes that provide material handling, fabrication, and preparation capability.

Funding for instrumentation is proposed at levels of approximately $\$ 12 \mathrm{M}$ annually over the next five years. At the end of FY-22, MFC will be equipped with a solid base of research instrumentation readily available to the broad nuclear energy research community. Beyond FY-22, a continued steady state funding level of $\$ 10-\$ 15 \mathrm{M}$ per year will expand the DOE-NE NRIC test bed capability and ensure that the suite of instruments remains current, reliable, and upgraded to meet user needs.

Table 6 provides a list of the instrumentation needs. This list will be reviewed annually and may be updated based on the needs of DOE-NE-funded programs, external users, updated NSUF gap analysis, instrument use, and development of new instrument technology.

The descriptions of each instrument or support system are provided in Appendix B.

Table 6. Summary of FY-18-FY-23 instrument development strategy and ROM cost estimates (\$K, FY-18 dollars).

\begin{tabular}{|c|c|c|c|c|c|c|c|c|c|c|c|c|}
\hline No. & $\begin{array}{l}\text { Facility } \\
\text { Name } \\
\end{array}$ & Capability & $\begin{array}{l}\text { Sustainment/ } \\
\text { Development }\end{array}$ & FY-18 & FY-19 & FY-20 & FY-21 & FY-22 & FY-23 & FY-24 & Outyears & Total \\
\hline 1 & IMCL & $\begin{array}{l}\text { Install Thermal } \\
\text { Properties Cell and } \\
\text { Glovebox (laser } \\
\text { flash, DSC, } \\
\text { thermogravimetric, } \\
\text { and dilatometry) } \\
\end{array}$ & Development & $\$ 3,500$ & & & & & & & & $\$ 3,500$ \\
\hline 2 & AFF & $\begin{array}{l}\text { Expanded Fuel } \\
\text { Fabrication } \\
\text { Capability } \\
\end{array}$ & Development & $\$ 3,500$ & & & & & & & & $\$ 3,500$ \\
\hline 3 & $\mathrm{AL}$ & $\begin{array}{l}\text { Mass } \\
\text { Spectrometers for } \\
\text { AL (Quad/ToF- } \\
\text { MS/LA-LIBS) }\end{array}$ & Sustainment & $\$ 3,800$ & & & & & & & & $\$ 3,800$ \\
\hline 4 & HFEF & $\begin{array}{l}\text { Complete GASR } \\
\text { and } \\
\text { Polisher/Grinder } \\
\text { Refurbishment }\end{array}$ & Sustainment & $\$ 1,500$ & & & & & & & & $\$ 1,500$ \\
\hline 5 & HFEF & $\begin{array}{l}\text { TREAT } \\
\text { Experiment } \\
\text { Handling Support } \\
\text { at HFEF }\end{array}$ & Sustainment & $\$ 1,000$ & & & & & & & & $\$ 1,000$ \\
\hline 6 & HFEF & $\begin{array}{l}\text { HFEF East } \\
\text { Radiography } \\
\text { Station Elevator } \\
\text { Repair }\end{array}$ & Sustainment & $\$ 1,000$ & & & & & & & & $\$ 1,000$ \\
\hline
\end{tabular}




\begin{tabular}{|c|c|c|c|c|c|c|c|c|c|c|c|c|}
\hline No. & $\begin{array}{l}\text { Facility } \\
\text { Name }\end{array}$ & Capability & $\begin{array}{l}\text { Sustainment/ } \\
\text { Development }\end{array}$ & FY-18 & FY-19 & FY-20 & FY-21 & FY-22 & FY-23 & FY-24 & Outyears & Total \\
\hline 7 & HFEF & $\begin{array}{l}\text { North } \\
\text { Radiography } \\
\text { Station Footprint } \\
\text { Repurpose } \\
\end{array}$ & Sustainment & $\$ 1,000$ & & & & & & & & $\$ 1,000$ \\
\hline 8 & $\mathrm{AL}$ & $\begin{array}{l}\text { Multi-Collector } \\
\text { ICP-MS }\end{array}$ & Sustainment & & $\$ 2,500$ & & & & & & & $\$ 2,500$ \\
\hline 9 & TREAT & $\begin{array}{l}\text { Re-establish } \\
\text { TREAT Na Loop } \\
\text { Capability }\end{array}$ & Development & & $\$ 10,000$ & & & & & & & $\$ 10,000$ \\
\hline 10 & FCF & $\begin{array}{l}\text { Establish NDA } \\
\text { capabilities in FCF }\end{array}$ & Development & & & $\$ 625$ & & & & & & $\$ 625$ \\
\hline 11 & IMCL & $\begin{array}{l}\text { Secondary Ion } \\
\text { Mass } \\
\text { Spectrometry } \\
\text { (Lab Investment) } \\
\end{array}$ & Development & & $\$ 600$ & & & & & & & $\$ 600$ \\
\hline 12 & IMCL & $\begin{array}{l}\text { Atom probe } \\
\text { tomography } \\
\text { instrument } \\
\text { (Lab Investment) }\end{array}$ & Development & & $\$ 4,500$ & & & & & & & $\$ 4,500$ \\
\hline 13 & TBD & $\begin{array}{l}\text { Process } \\
\text { development for } \\
\text { large-scale fuel } \\
\text { castings }\end{array}$ & Development & & & $\$ 500$ & $\$ 500$ & & & & & $\$ 1,000$ \\
\hline 14 & $\mathrm{AL}$ & $\begin{array}{l}\text { Gas mass } \\
\text { spectrometer }\end{array}$ & Sustainment & & & $\$ 1,500$ & & & & & & $\$ 1,500$ \\
\hline 15 & HFEF & $\begin{array}{l}\text { Replace LEICA } \\
\text { metallograph }\end{array}$ & Sustainment & & & $\$ 300$ & & & & & & $\$ 300$ \\
\hline 16 & $\begin{array}{l}\text { FASB/ } \\
\text { HFEF }\end{array}$ & $\begin{array}{l}\text { Digital Image } \\
\text { Correlation for } \\
\text { Mechanical } \\
\text { Testing } \\
\end{array}$ & Development & & & $\$ 200$ & & & & & & \\
\hline 17 & $\mathrm{AL}$ & $\begin{array}{l}\text { B-wing ICP-OES } \\
\text { (non-rad) }\end{array}$ & Sustainment & & & $\$ 300$ & & & & & & $\$ 300$ \\
\hline 18 & FASB & $\begin{array}{l}\text { Tailored } \\
\text { enrichment } \\
\text { capability - } \\
\text { Calcine }\end{array}$ & Development & & & $\$ 500$ & & & & & & $\$ 500$ \\
\hline 19 & HFEF & $\begin{array}{l}\text { Improved } \\
\text { electronic interface } \\
\text { for hot cell scales } \\
\text { and balances }\end{array}$ & Sustainment & & & $\$ 200$ & $\$ 200$ & & & & & $\$ 400$ \\
\hline 20 & EML & $\begin{array}{l}\text { Replace Quanta } \\
\text { Focused Ion Beam }\end{array}$ & Sustainment & & & $\$ 1,350$ & & & & & & \\
\hline 21 & $\mathrm{AL}$ & $\begin{array}{l}\text { Expanded CNO } \\
\text { capability }\end{array}$ & New & & & $\$ 600$ & & & & & & $\$ 600$ \\
\hline 22 & RCL & $\begin{array}{l}\text { Tailored } \\
\text { enrichment } \\
\text { capability } \\
\text { demonstration - } \\
\text { aqueous precursor }\end{array}$ & Development & & & $\$ 1,000$ & & & & & & $\$ 1,000$ \\
\hline 23 & HFEF & $\begin{array}{l}\text { Visual Mount } \\
\text { Inspection System } \\
\text { in the HFEF } \\
\text { Containment Box }\end{array}$ & Development & & & $\$ 1,000$ & & & & & & $\$ 1,000$ \\
\hline 24 & NRAD & $\begin{array}{l}\text { Develop Digital } \\
\text { Radiography } \\
\text { Capabilities in } \\
\text { HFEF }\end{array}$ & Development & & & $\$ 550$ & $\$ 600$ & $\$ 400$ & & & & $\$ 1,550$ \\
\hline 25 & $\mathrm{AL}$ & Replace TIMS & Sustainment & & & $\$ 1,000$ & $\$ 1,000$ & & & & & $\$ 2,000$ \\
\hline 26 & $\mathrm{AFF}$ & $\begin{array}{l}\text { Versatile fuel form } \\
\text { capability Phase } 1 \text { : } \\
\text { Metal alloy } \\
\text { atomization }\end{array}$ & Development & & & $\$ 500$ & $\$ 2,500$ & & & & & $\$ 3,000$ \\
\hline 27 & IMCL & $\begin{array}{l}\text { In-situ mechanical } \\
\text { testing for Titan } \\
\text { TEM }\end{array}$ & Development & & & $\$ 450$ & & & & & & \\
\hline 28 & HFEF & $\begin{array}{l}\text { Update PGS in } \\
\text { HFEF }\end{array}$ & Sustainment & & & & $\$ 1,000$ & & & & & $\$ 1,000$ \\
\hline 29 & $\mathrm{AL}$ & $\begin{array}{l}\text { Ion } \\
\text { Chromatography }\end{array}$ & Sustainment & & & & $\$ 200$ & & & & & $\$ 200$ \\
\hline 30 & HFEF & $\begin{array}{l}\text { Replace Leitz } \\
\text { Metallograph in } \\
\text { MetBox with SEM }\end{array}$ & Sustainment & & & & $\$ 1,500$ & & & & & $\$ 1,500$ \\
\hline
\end{tabular}




\begin{tabular}{|c|c|c|c|c|c|c|c|c|c|c|c|c|}
\hline No. & $\begin{array}{l}\text { Facility } \\
\text { Name }\end{array}$ & Capability & $\begin{array}{l}\text { Sustainment/ } \\
\text { Development }\end{array}$ & FY-18 & FY-19 & FY-20 & FY-21 & FY-22 & FY-23 & FY-24 & Outyears & Total \\
\hline 31 & NRAD & $\begin{array}{l}\text { Develop neutron } \\
\text { diffraction } \\
\text { capability in HFEF } \\
\text { (NRS) }\end{array}$ & Sustainment & & & & $\$ 565$ & $\$ 485$ & $\$ 500$ & & & $\$ 1,550$ \\
\hline 32 & IMCL & $\begin{array}{l}\text { Ion Mill (PIPS-II) } \\
\text { for Sample } \\
\text { Preparation } \\
\end{array}$ & Development & & & & $\$ 300$ & & & & & $\$ 300$ \\
\hline 34 & $\mathrm{AL}$ & $\begin{array}{l}\text { Gas } \\
\text { chromatograph }\end{array}$ & Development & & & & $\$ 400$ & & & & & $\$ 400$ \\
\hline 35 & $\begin{array}{l}\mathrm{HFEF} / \\
\mathrm{IMCL}\end{array}$ & $\begin{array}{l}\text { Raman } \\
\text { spectroscopy for } \\
\text { nuclear fuel and } \\
\text { cladding } \\
\text { characterization }\end{array}$ & Development & & & & $\$ 550$ & & & & & $\$ 550$ \\
\hline $\begin{array}{c}\text { Not } \\
\text { Prioritized }\end{array}$ & TBD & $\begin{array}{l}\text { Fabricate (2) } \\
\text { Iridium Crucibles } \\
\text { to Support R\&D }\end{array}$ & Development & & & & & & & & & $\$ 150$ \\
\hline $\begin{array}{c}\text { Not } \\
\text { Prioritized }\end{array}$ & HFEF & $\begin{array}{l}\text { ECP/EBLM } \\
\text { refurbishment }\end{array}$ & Sustainment & & & & & & & $\$ 750$ & & $\$ 750$ \\
\hline $\begin{array}{c}\text { Not } \\
\text { Prioritized }\end{array}$ & $\mathrm{AL}$ & $\begin{array}{l}\text { Agilent or Thermo } \\
\text { triple quad ICP- } \\
\text { MS }\end{array}$ & Sustainment & & & & & $\$ 700$ & & & & $\$ 700$ \\
\hline $\begin{array}{c}\text { Not } \\
\text { Prioritized }\end{array}$ & IMCL & $\begin{array}{l}\text { High Throughput } \\
\text { Sample } \\
\text { Preparation } \\
\text { Capability for } \\
\text { Nuclear Fuel } \\
\end{array}$ & Development & & & & & $\$ 310$ & & & & \\
\hline $\begin{array}{c}\text { Not } \\
\text { Prioritized }\end{array}$ & TBD & $\begin{array}{l}\text { Powder Bed } \\
\text { Additive } \\
\text { Manufacturing }\end{array}$ & Development & & & & & $\$ 1,000$ & & & & \\
\hline $\begin{array}{c}\text { Not } \\
\text { Prioritized }\end{array}$ & NRAD & $\begin{array}{l}\text { NRAD digital } \\
\text { neutron } \\
\text { radiography/tomog } \\
\text { raphy }\end{array}$ & Development & & & & & $\$ 500$ & $\$ 1,000$ & $\$ 1,000$ & & $\$ 2,500$ \\
\hline $\begin{array}{c}\text { Not } \\
\text { Prioritized }\end{array}$ & FASB & $\begin{array}{l}\text { Differential } \\
\text { scanning } \\
\text { calorimetry } \\
\text { instrument } \\
\end{array}$ & Development & & & & & $\$ 220$ & & & & $\$ 220$ \\
\hline $\begin{array}{c}\text { Not } \\
\text { Prioritized }\end{array}$ & FMF & $\begin{array}{l}\text { Micro x-ray } \\
\text { tomography } \\
\text { capability }\end{array}$ & Development & & & & & $\$ 1,000$ & & & & $\$ 1,000$ \\
\hline $\begin{array}{c}\text { Not } \\
\text { Prioritized } \\
\end{array}$ & NRAD & $\begin{array}{l}\text { NRS Elevator } \\
\text { Upgrade }\end{array}$ & Sustainment & & & & & $\$ 1,000$ & $\$ 1,000$ & & & $\$ 2,000$ \\
\hline $\begin{array}{c}\text { Not } \\
\text { Prioritized }\end{array}$ & FMF & $\begin{array}{l}\text { Research scale } \\
\text { TRU casting } \\
\text { system and GB } \\
\end{array}$ & Development & & & & & $\$ 500$ & $\$ 2,500$ & $\$ 2,000$ & & $\$ 5,000$ \\
\hline $\begin{array}{c}\text { Not } \\
\text { Prioritized }\end{array}$ & HFEF & $\begin{array}{l}\text { Shielded multi- } \\
\text { instrument non- } \\
\text { destructive PIE } \\
\text { capability }\end{array}$ & Development & & & & & $\$ 500$ & $\$ 2,000$ & $\$ 3,000$ & $\$ 12,000$ & $\$ 17,500$ \\
\hline $\begin{array}{c}\text { Not } \\
\text { Prioritized }\end{array}$ & NRAD & $\begin{array}{l}\text { NRS Sample } \\
\text { Preparation } \\
\text { Glovebox } \\
\end{array}$ & Development & & & & & & $\$ 500$ & $\$ 500$ & & $\$ 1,000$ \\
\hline $\begin{array}{c}\text { Not } \\
\text { Prioritized }\end{array}$ & NRAD & $\begin{array}{l}\text { Digital neutron } \\
\text { radiography/tomog } \\
\text { raphy }\end{array}$ & Development & & & & & & & $\$ 2,500$ & & $\$ 2,500$ \\
\hline $\begin{array}{c}\text { Not } \\
\text { Prioritized } \\
\end{array}$ & EML & $\begin{array}{l}\text { Replace EML } \\
\text { SEM }\end{array}$ & Sustainment & & & & & & & $\$ 1,000$ & & $\$ 1,000$ \\
\hline $\begin{array}{c}\text { Not } \\
\text { Prioritized } \\
\end{array}$ & FASB & $\begin{array}{l}\text { IASCC shielded } \\
\text { cell \#2 (FASB) } \\
\end{array}$ & Development & & & & & & & & $\$ 8,500$ & $\$ 8,500$ \\
\hline $\begin{array}{c}\text { Not } \\
\text { Prioritized }\end{array}$ & NRAD & $\begin{array}{l}\text { NRS Control } \\
\text { Console } \\
\text { Replacement } \\
\end{array}$ & Sustainment & & & & & & & & $\$ 370$ & $\$ 370$ \\
\hline $\begin{array}{c}\text { Not } \\
\text { Prioritized }\end{array}$ & FASB & $\begin{array}{l}\text { Pushrod } \\
\text { dilatometer } \\
\text { Instrument }\end{array}$ & Development & & & & & & & & $\$ 225$ & $\$ 225$ \\
\hline
\end{tabular}




\begin{tabular}{|c|c|c|c|c|c|c|c|c|c|c|c|c|}
\hline No. & $\begin{array}{l}\text { Facility } \\
\text { Name }\end{array}$ & Capability & $\begin{array}{l}\text { Sustainment/ } \\
\text { Development }\end{array}$ & FY-18 & FY-19 & FY-20 & FY-21 & FY-22 & FY-23 & FY-24 & Outyears & Total \\
\hline $\begin{array}{c}\text { Not } \\
\text { Prioritized }\end{array}$ & IMCL & $\begin{array}{l}\text { Argon atmosphere } \\
\text { in Shielded } \\
\text { Sample } \\
\text { Preparation Area } \\
\text { (SSPA) }\end{array}$ & Development & & & & & & & & $\$ 1,500$ & $\$-$ \\
\hline $\begin{array}{c}\text { Not } \\
\text { Prioritized }\end{array}$ & NRAD & $\begin{array}{l}\text { NRAD Automated } \\
\text { Computed } \\
\text { Tomography } \\
\text { system } \\
\end{array}$ & Development & & & & & & & & $\$ 2,400$ & $\$ 2,400$ \\
\hline $\begin{array}{c}\text { Not } \\
\text { Prioritized }\end{array}$ & MFC & $\begin{array}{l}\text { Research data } \\
\text { management and } \\
\text { visualization } \\
\text { system } \\
\end{array}$ & Development & & & & & & & & $\$ 2,250$ & $\$ 2,250$ \\
\hline $\begin{array}{c}\text { Not } \\
\text { Prioritized }\end{array}$ & FASB & $\begin{array}{l}\text { Oxide reduction } \\
\text { furnace for } \\
\text { Pyrochemical } \\
\text { Glovebox (PCG) - } \\
\text { (Program Funded) }\end{array}$ & Development & & & & & & & & $\$ 300$ & $\$ 300$ \\
\hline $\begin{array}{c}\text { Not } \\
\text { Prioritized }\end{array}$ & FASB & $\begin{array}{l}\text { Electrorefiner for } \\
\text { PCG - } \\
\text { (Program Funded) }\end{array}$ & Development & & & & & & & & $\$ 300$ & $\$ 300$ \\
\hline $\begin{array}{c}\text { Not } \\
\text { Prioritized }\end{array}$ & FASB & $\begin{array}{l}\text { Distillation } \\
\text { furnace for PCG - } \\
\text { (Program Funded) }\end{array}$ & Development & & & & & & & & $\$ 200$ & $\$ 200$ \\
\hline $\begin{array}{c}\text { Not } \\
\text { Prioritized }\end{array}$ & FASB & $\begin{array}{l}\text { Fermi MEDE } \\
\text { furnace for PCG - } \\
\text { (Program Funded) }\end{array}$ & Development & & & & & & & & $\$ 2,000$ & $\$ 2,000$ \\
\hline $\begin{array}{c}\text { Not } \\
\text { Prioritized }\end{array}$ & FASB & $\begin{array}{l}\text { MK } 1 \text { multi- } \\
\text { function furnace } \\
\text { for PCG - } \\
\text { (Program Funded) }\end{array}$ & Development & & & & & & & & $\$ 2,000$ & $\$ 2,000$ \\
\hline $\begin{array}{c}\text { Not } \\
\text { Prioritized }\end{array}$ & FASB & $\begin{array}{l}\text { Molten salt } \\
\text { furnace for PCG - } \\
\text { (Program Funded) }\end{array}$ & Development & & & & & & & & $\$ 50$ & $\$ 50$ \\
\hline $\begin{array}{c}\text { Not } \\
\text { Prioritized }\end{array}$ & FASB & $\begin{array}{l}\text { Larinda furnace } \\
\text { for PCG - } \\
\text { (Program Funded) }\end{array}$ & Development & & & & & & & & $\$ 200$ & $\$ 200$ \\
\hline & & $\begin{array}{l}\text { Annual Totals } \\
\text { (NE only) }\end{array}$ & & $\$ 15,300$ & $\$ 12,500$ & $\$ 10,575$ & $\$ 9,815$ & $\$ 9,865$ & $\$ 10,000$ & $\$ 10,750$ & & $\$ 111,290$ \\
\hline \multirow{2}{*}{\multicolumn{4}{|c|}{$\begin{array}{l}\text { Mission } \\
\text { Enablement } \\
\quad \text { Grand total } \\
\end{array}$}} & $\$ 9,900$ & $\$ 25,000$ & $\$ 25,750$ & $\$ 26,523$ & $\$ 27,318$ & $\$ 28,138$ & $\$ 28,138$ & & \\
\hline & & & & $\$ 25,200$ & $\$ 37,500$ & $\$ 36,325$ & $\$ 36,338$ & $\$ 37,183$ & $\$ 38,138$ & $\$ 38,888$ & & \\
\hline \multicolumn{4}{|c|}{$\begin{array}{l}\text { Potential to seek indirect lab investments or other } \\
\text { program funding. It is not anticipated that IFM will fund } \\
\text { these items. }\end{array}$} & \multicolumn{4}{|c|}{$\begin{array}{l}\text { Green shaded rows represent scope authorized to } \\
\text { proceed }\end{array}$} & \multicolumn{5}{|c|}{$\begin{array}{l}\text { NOTE: These are conceptual cost estimates and will } \\
\text { change as planning matures }\end{array}$} \\
\hline
\end{tabular}

\subsubsection{TREAT Reactor Instrumentation Development Strategy}

INL-LTD-15-33324 provides an overview of the capabilities required for conducting experiments in TREAT. These capabilities are introduced sequentially as the complexity of transient testing increases and fuel types range from LWR to advanced fuels. The objective over the last several years has been to establish the baseline capsule testing capabilities in time to coincide with resumption of TREAT reactor operations. These baseline capabilities provide the initial transient testing services required for projects and programs with near-term needs (e.g., the NTRD Accident Tolerant Fuels Program). The baseline capability includes equipment, facilities, and expertise to perform basic transient tests using static capsules. These capabilities will need to advance significantly to include prototypic environments (pressure, temperature, and recirculating coolant) and state of the art in-pile instrumentation over the 5-year period FY-19-FY-23 to continue to meet the nuclear fuel technology development objectives.

Additional TREAT capabilities are required for experiment handling, experiment vehicles, experiment instrumentation, and PIE functions.

TREAT instrument funding needs and proposed funding sources are provided in Table 7 . The descriptions of each instrument or support system are provided in Appendix C. 
Table 7. Summary of FY-19-FY-23 Transient testing scientific and enabling infrastructure development strategy and ROM cost estimates (\$K, FY-19 dollars).

\begin{tabular}{|c|c|c|c|c|c|c|c|c|c|}
\hline \multicolumn{2}{|r|}{ Transient Testing Experiment Scientic and Enabling Infrastras tructure } & Funding source & FY19 & FY20 & FY21 & FY22 & FY23 & Totals & Comments \\
\hline \multirow{3}{*}{ 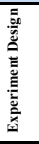 } & Integration & & & & & & & & \\
\hline & TREAT S cientific Coordinator s upport & & & & & & & & \\
\hline & TREAT Scientific Coordinator & TBD & & $\$ 800$ & $\$ 800$ & $\$ 800$ & $\$ 800$ & $\$ 3,200$ & Supported by NSUF FY14-FY18 \\
\hline \multirow{13}{*}{ 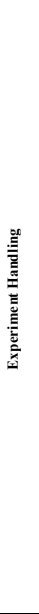 } & Experiment Preparation Benches and Transport Casks & & & & & & & & \\
\hline & Experiment preparation & & & & & & & & \\
\hline & Shielded Experiment Handling Cell (MFC 723) - Conceptual Design & NE-42 (AFC) & $\$ 800$ & & & & & $\$ 800$ & \\
\hline & Shielded Experiment Handling Cell (MFC 723) & TBD & & $\$ 2,500$ & $\$ 1,500$ & & & $\$ 4,000$ & $\begin{array}{l}\text { Design based on copy of the IMCL TPC. May require } \\
\text { slightly thicker shielding. }\end{array}$ \\
\hline & Capsule and Loop handling and checkout system in HFEF & TBD & & $\$ 1,000$ & $\$ 1,000$ & $\$ 2,000$ & $\$ 2,000$ & $\$ 6,000$ & \\
\hline & $\begin{array}{l}\text { TREAT Experiment Support Building (MFC } 723 \text { Updgrade) - Conceptual } \\
\text { Design }\end{array}$ & $\mathrm{NE}-3$ (IFM) & $\$ 500$ & & & & & $\$ 500$ & \\
\hline & TREAT Experiment Support Building (MFC 723 Updgrade) & TBD & & $\$ 2,500$ & $\$ 2,500$ & & & $\$ 5,000$ & $\begin{array}{l}\text { Includes ventilation upgrades, building reconfiguraiton, } \\
\text { etc. }\end{array}$ \\
\hline & Experiment Assembly/Disassembly & $\mathrm{NE}-3$ (IFM) & & $\$ 500$ & $\$ 1,000$ & $\$ 1,000$ & & $\$ 2,500$ & $\begin{array}{l}\text { Generic Test Train Assembly Facility (TTAF) type } \\
\text { capability to support experiment programs. }\end{array}$ \\
\hline & Transport and Storage Casks & & & & & & & & \\
\hline & International shipping container for small irradiated samples & $\mathrm{NE}-42$ (AFC) & $\$ 100$ & & & & & $\$ 100$ & $\begin{array}{l}\text { Qualification of HFEF to receive TN-LAB int' cask (total } \\
\text { cost of } \sim 550 \mathrm{~K} \text { shared with other programs) }\end{array}$ \\
\hline & Remanufacturing Bench for Irradiated Fuel Pins & & & & & & & & \\
\hline & Re-Fabrication Bench for Irradiated Fuel Pins & $\mathrm{NE}-42(\mathrm{AFC})$ & $\$ 500$ & $\$ 500$ & & & & $\$ 1,000$ & \begin{tabular}{|l|} 
Contract with Halden to implement and commission system \\
in HFEF. Expect $\sim 3,500 \mathrm{k}$ for bench fabrication. No funding \\
source or cost estimate for out years is provided.
\end{tabular} \\
\hline & Advanced fuel pin remanufacturing and instrumentation bench & $\mathrm{NE}-42$ (AFC) \& NE-5 (12) & $\$ 200$ & $\$ 1,000$ & $\$ 1,500$ & & & $\$ 2,700$ & $\begin{array}{l}\text { Contract with Halden to implement and commission system } \\
\text { in } 723 \text { cell }\end{array}$ \\
\hline \multirow{10}{*}{ 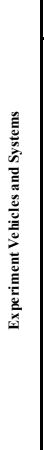 } & Experiment Vehicles & & & & & & & & \\
\hline & Static Capsule Devices & & & & & & & & \\
\hline & Advanced Modules for MARCH System & $\begin{array}{l}\text { NE-51 (NEUP), NE-42 (AFC), } \\
\text { \& LDRD }\end{array}$ & $\$ 1,000$ & $\$ 1,000$ & $\$ 1,000$ & & & $\$ 3,000$ & $\begin{array}{l}\text { Includes visualiztion capsule. Base capability being } \\
\text { developed under LDRD }\end{array}$ \\
\hline & MARCH-SERTTA & $\mathrm{NE}-42$ (AFC) & $\$ 3,000$ & & & & & $\$ 3,000$ & \\
\hline & Super-SERTTA & $\mathrm{NE}-42(\mathrm{AFC})$ & $\$ 3,000$ & $\$ 3,000$ & & & & $\$ 6,000$ & \\
\hline & Recirculating Loops & & & & & & & & \\
\hline & $\begin{array}{l}\text { TWERL: TREAT Water Environment Recirculating Loop - Conceptual } \\
\text { Design }\end{array}$ & $\mathrm{NE}-42$ (AFC) & $\$ 500$ & & & & & $\$ 500$ & \\
\hline & TWERL: TREAT Water Environment Recirculating Loop & TBD & & $\$ 1,000$ & $\$ 4,000$ & $\$ 3,000$ & $\$ 3,000$ & $\$ 11,000$ & \\
\hline & Recirculating sodium loop system & $\mathrm{NE}-3$ (IFM) & $\$ 5,000$ & $\$ 5,000$ & $\$ 2,000$ & & & $\$ 12,000$ & $\begin{array}{l}\text { Project forward funded \$10M through 2021. Executed in } \\
\text { collaboration with Terrapower }\end{array}$ \\
\hline & Multi-pin Test Vehicle & TBD & & & $\$ 1,000$ & $\$ 1,500$ & $\$ 1,500$ & $\$ 4,000$ & \\
\hline \multirow{16}{*}{ 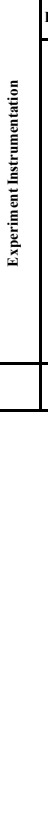 } & Provide instrumentation to monitor core and fuel behavior during transients & & & & & & & & \\
\hline & Fuel Motion Monitoring & & & & & & & & \\
\hline & Hodoscope Operations and Maintanence & TBD & & $\$ 300$ & $\$ 300$ & $\$ 300$ & $\$ 300$ & $\$ 1,200$ & \\
\hline & Full View Hodoscope (Refurbish all 360 channel system) & $\mathrm{NE}-42$ (AFC) & $\$ 1,000$ & & & & & $\$ 1,000$ & \\
\hline & Develop Next Generation Fuel Motion Monitoring System & $\mathrm{NE}-42$ (AFC) & $\$ 400$ & & & & & $\$ 400$ & \\
\hline & Develop Next Generation Fuel Motion Monitoring System & TBD & & $\$ 1,000$ & $\$ 1,000$ & $\$ 1,000$ & $\$ 1,000$ & $\$ 4,000$ & Project funded for FY19 by NE-42 (AFC) \\
\hline & TREAT in-pile instrumentation & & & & & & & & \\
\hline & Advanced Transient Instrumentation Development & $\mathrm{NE}-5$ (12) \& NE-42 (AFC) & $\$ 1,000$ & $\$ 2,000$ & $\$ 2,000$ & $\$ 2,000$ & $\$ 2,000$ & $\$ 9,000$ & \\
\hline & Scientific and Enabling Infrastructure (\$K) & & $\$ 17,000$ & $\$ 22,100$ & $\$ 19,600$ & $\$ 11,600$ & $\$ 10,600$ & $\$ 80,900$ & \\
\hline & & Funding source & FY19 & FY20 & FY21 & FY22 & FY23 & Totals & \\
\hline & & $\mathrm{NE}-3$ (IFM) & $\$ 5,500$ & $\$ 5,500$ & $\$ 3,000$ & $\$ 1,000$ & \$o & $\$ 15,000$ & \\
\hline & & $\mathrm{NE}-42$ (AFC) & $\$ 9,300$ & $\$ 3,500$ & so & so & so & $\$ 12,800$ & \\
\hline & & $\mathrm{NE}-42(\mathrm{AFC}) \& \mathrm{NE}-5(12)$ & $\$ 1,200$ & $\$ 3,000$ & $\$ 3,500$ & $\$ 2,000$ & $\$ 2,000$ & $\$ 11,700$ & \\
\hline & & $\begin{array}{l}\text { NE-51 (NEUP), NE-42 (AFC), } \\
\& \text { LDRD }\end{array}$ & $\$ 1,000$ & $\$ 1,000$ & $\$ 1,000$ & so & $\$ 0$ & $\$ 3,000$ & \\
\hline & & TBD & so & $\$ 9,100$ & $\$ 12,100$ & $\$ 8,600$ & $\$ 8,600$ & $\$ 38,400$ & \\
\hline & & & & & & & & $\$ 80,900$ & \\
\hline
\end{tabular}




\section{MFC CAMPUS VISION}

MFC is a central part of the NE test bed and NRIC vision and the future growth associated with this concept. To support advanced nuclear technology development, the nuclear energy technology RD\&D must progress further up the technology readiness-level scale towards the demonstration and deployment phases. The MFC campus vision comprises a refurbishment and replacement campaign within the facilities that provide these new capabilities along with a strategy to expand, replace, and relocate capabilities to support the growing test bed needs. These new facilities are described below and range in maturity from planned construction and line-item critical decision (CD) progress to conceptual planning beyond the current five-year window. These encompass the need for expanded research and infrastructure capabilities anticipated to support growth related to maturing the NE NRIC. Capabilities such as a large scale demonstration and deployment capability (e.g., expanded fabrication, mock-up, and testing) are identified with input from the research community and industry.

The campus vision includes a revised overall layout of MFC, locating research facilities and support facilities into separate geographic areas of the campus to increase efficiency of the flow of research execution and decrease congestion and logistical conflicts. PIE RD\&D facilities, are focused in the NW quadrant of MFC site near HFEF and IMCL. Current and future fuel fabrication RD\&D facilities are located in the SE quadrant near FMF. Current and potential future analytical laboratory research and support capabilities will remain in the central or SW portions of the campus to support all research areas. Industrial support services will move to the NE quadrant. Traffic will be rerouted around the perimeter of MFC to reduce vehicle and equipment interaction with research and support staff and provide more direct access to research and industrial portions of MFC.

Additional elements that complement the proposed new facilities will also be addressed as part of the campus vision. Footprint reduction will be leveraged to provide additional expansion space within the fence and reduce the resources required to manage and maintain aging infrastructure beyond intended service life. Facility support infrastructure such as electrical and transportation infrastructure, utility loops, and general facility systems refurbishment and replacement will be addressed as funding allows. Deferred maintenance backlog and repair needs will be targeted. Transportation flow, site drainage, parking, and general roads and grounds will be reviewed with respect to the future campus design. Sustainability activities such as xeriscaping and LED light replacement will be implemented as funding allows.

There are three primary areas for campus development at MFC:

1. Direct DOE-NE funding for capital asset projects that can include General Purpose Project (GPP) construction and line item construction projects of new facilities or refurbishment of existing nuclear and radiological facility systems;

2. Direct operating funded nuclear infrastructure efforts such as updating or refurbishing existing nuclear and radiological facilities and their associated structures and systems (e.g., structural, electrical, or HVAC related activities), and efforts such as sustainability, legacy material disposition, and footprint reduction; and

3. Laboratory-funded investments including general-use buildings, structures, and support infrastructure. Examples here are building roofs and skins, utilities and HVAC, lighting replacement, parking, sidewalks and pavement, and other sustainability efforts. 


\subsection{MFC Capital Asset and Direct Nuclear Infrastructure}

Two new capital asset construction projects are the MFC Research Collaboration Building GPP (in construction) and the line item Sample Preparation Laboratory (in design). Both are described in the following sections. Other facilities in much more conceptual phases are also generally described. None of the conceptual facilities have been estimated for cost and are all pre-mission need. These are identified below in Figure 4 and are described generally in the following sections.

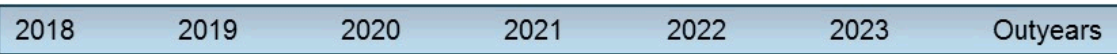

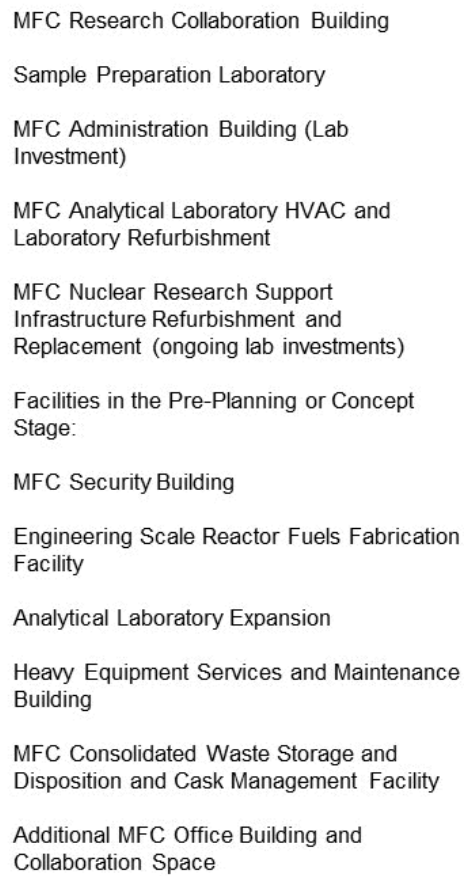

Figure 4. MFC Campus Vision Conceptual Time Frames for Capital Asset and Nuclear Infrastructure. 


\subsubsection{MFC Research Collaboration Building}

\section{Description}

A major role of DOE-NE in advancing nuclear technology is to bring the best and brightest scientists together in a cooperative manner to resolve technical challenges in nuclear energy. The interaction of scientists and engineers at the working level ensures that innovative ideas, supported by data, can be translated to workable technology solutions.

\section{Benefits}

This facility provides much needed collaboration space and will enable close interaction between INL researchers and technical staff with visiting users from outside the INL and the United States. This allows technical staff to support key experiment discussions, design, and logistical activities at a location adjacent to the test bed without having to travel away from their work locations and provides visiting users close proximity to MFC.

\section{Facility Risk}

MFC office space is currently nearly $100 \%$ occupied. As use of IMCL grows and SPL achieves operational status and the number of outside researchers using MFC is projected to grow beyond 200 per year in approximately 2022, additional collaborative research space is needed where research teams, consisting of INL researchers, visiting researchers and engineers, and other key technical support can collaborate and use advanced data analysis and visualization tools to resolve technical challenges.

Estimated Cost: $\$ 9.5 \mathrm{M}$ TPC.

Status: Planning and design began in FY-17 with CD-0 approval with facility completion planned in FY-19.

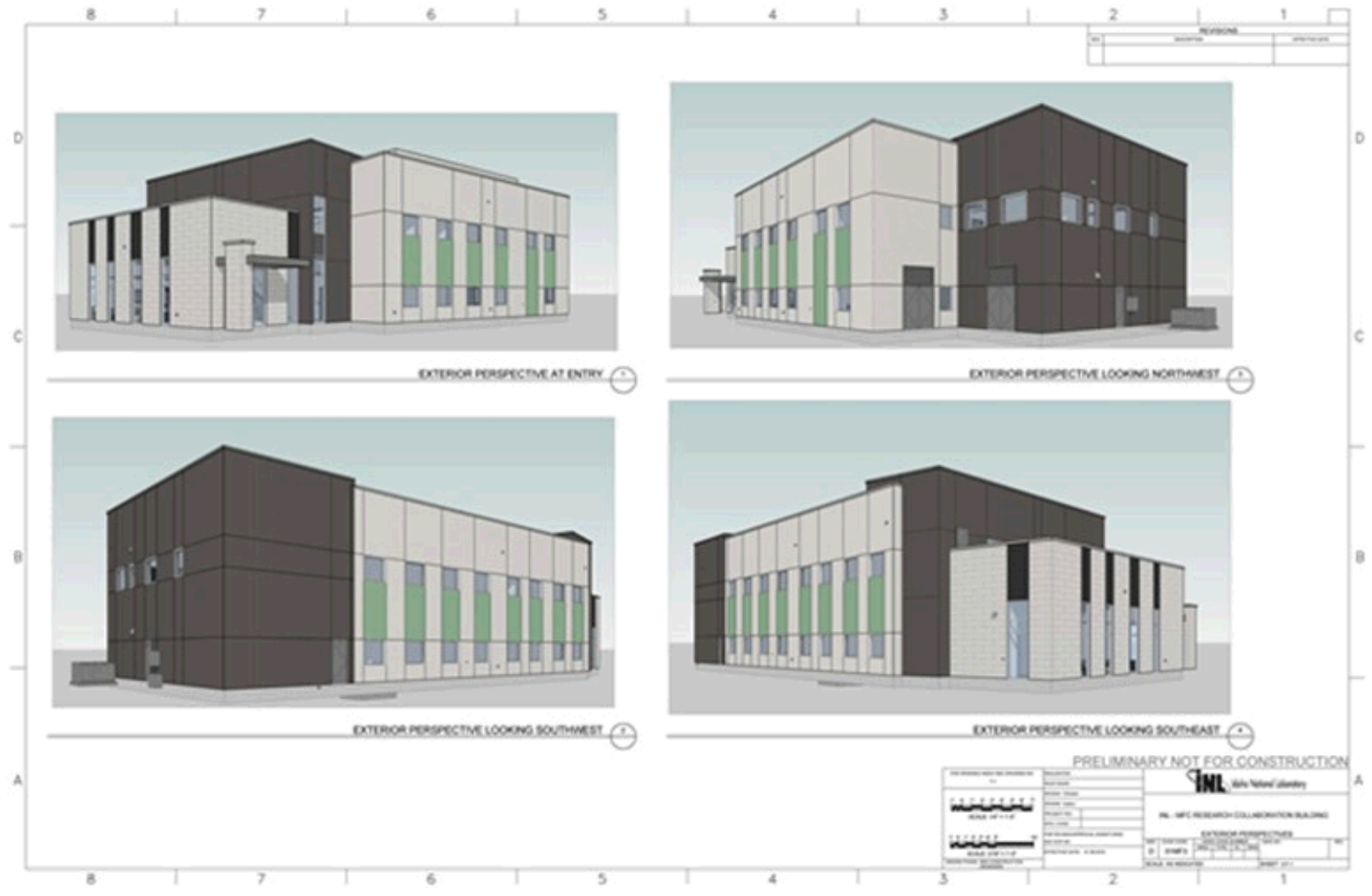




\subsubsection{Sample Preparation Laboratory}

\section{Description}

The Sample Preparation Laboratory (SPL) is focused on analysis of irradiated structural materials. It closes an identified nuclear energy research capability gap by greatly increasing sample throughput and nanoscale research capability. SPL will provide a central hub for DOE-NE research collaborations because of its world-class instrumentation and ability to prepare, analyze, and ship alpha-free materials to universities, industry partners, and other DOE user facilities for research. This network provides specialized capabilities and access to a greater portion of the national intellectual capital.

\section{Benefits}

The proposed laboratory will include capabilities that will allow high-hazard materials to be routinely prepared and tested in a safe, secure, and environmentally controlled environment. SPL provides a key link between DOE-NE's core research functions at MFC and ATR and the broader nuclear energy research community. Materials free from alpha contamination can be sized appropriately, packaged, and transported to other national user facilities, universities, commercial, and international sites. In addition, this laboratory will complete the suite of facilities fulfilling near-term advanced post-irradiation examination (along with HFEF and IMCL) needs that will serve as a center for advanced fuels and materials characterization, as well as development of new processes, tools, and instruments to further research.

\section{Facility Risk}

This facility will provide world-class structural material analysis capabilities focusing on non-fuel sample preparation, mechanical properties and failure modes, and micro/nano structural materials characterization. This capability is crucial to growing the DOE-NE test bed capabilities, to support advanced reactor RD\&D up through demonstration, and to ensure LWR life extension.

Estimated Cost: Project costs reflect upper end of the cost range approved at CD-1 is $\$ 98.2 \mathrm{M} \mathrm{TPC}$.

Status: SPL currently has an approved CD-1 facility design and CD-2/3 is in progress.

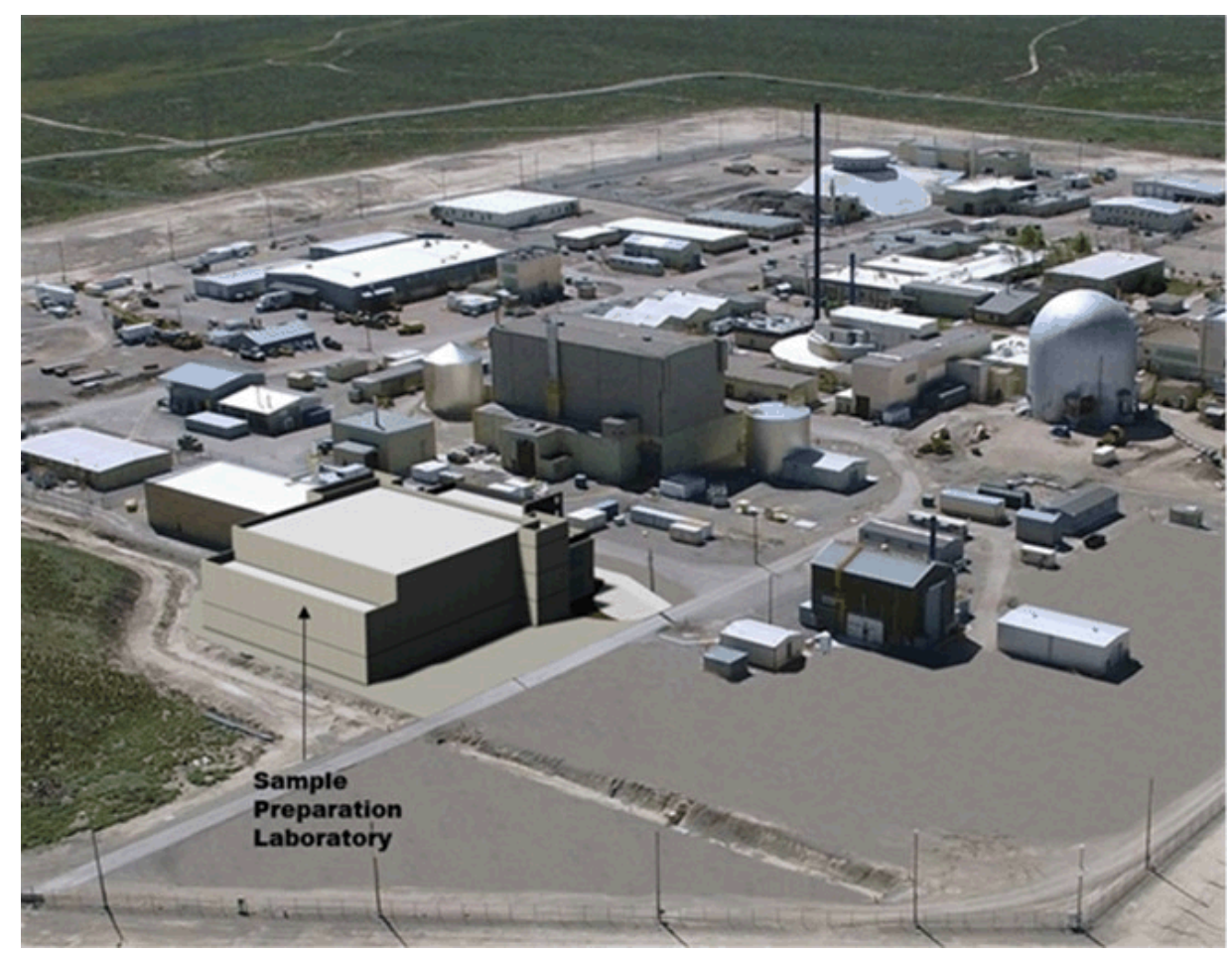




\subsubsection{MFC Administration Building}

\section{Description}

MFC is a central cog of the NRIC test bed concept. As such, there must be facilities available to support the anticipated growth of research and technical support staff. Modernizing aging capabilities such as cafeteria services and adequate office space also supports attracting and retaining personnel critical to support the growth of the test bed. A new administrative building is being designed to replace capabilities well past their design life. This building is a key component of a modern nuclear energy research test bed at the INL.

\section{Benefit}

The current MFC cafeteria infrastructure/equipment is antiquated and has been in service for decades. Considerable time is spent each year addressing facility reliability issues such as unclogging discharge piping. Code compliance is also at risk with this aging infrastructure. Completion of the proposed administrative building that includes a cafeteria will greatly enhance large capacity meeting capability and provide for more professional food service for MFC employees and visiting tour groups and dignitaries. This facility will also provide at least 60 additional office spaces which will support mission growth as well as replace aging modular facilities that are approaching 40 years old.

\section{Risk}

New support infrastructure is required to replace aging and less than adequate modular structures currently exceeding capacity to house existing staff. Many of the office buildings are decades beyond their intended design life. For example, MFC-717 (currently at 107\% capacity) was acquired in 1985, MFC-713 (98\% capacity) was acquired in 1978, and MFC-714 (233\% capacity) was acquired in 1977. There are also numerous unplumbed smaller trailers such as MFC-TR-56 (98\% capacity) and MFC-TR-57 (81\% capacity), located at MFC in the mid-2000s that were originally leased and used by the Idaho Cleanup Project contractor to support operations at MFC. None of these facilities was ever intended to provide long term permanent offices for MFC personnel. Most of the large modular offices are in a degraded condition.

The current MFC food services cafeteria, large meeting support areas, training space, and administrative and support offices are inadequate to house a population that has increased to over 1,000 personnel. Expected project growth will further burden housing that is overcapacity. There is no room for the additional personnel required to support the growing mission at MFC.

Estimated Cost: The targeted cost range is $\$ 16 \mathrm{M}-\$ 20 \mathrm{M}$.

Status: This lab investment has been authorized to proceed with conceptual design.

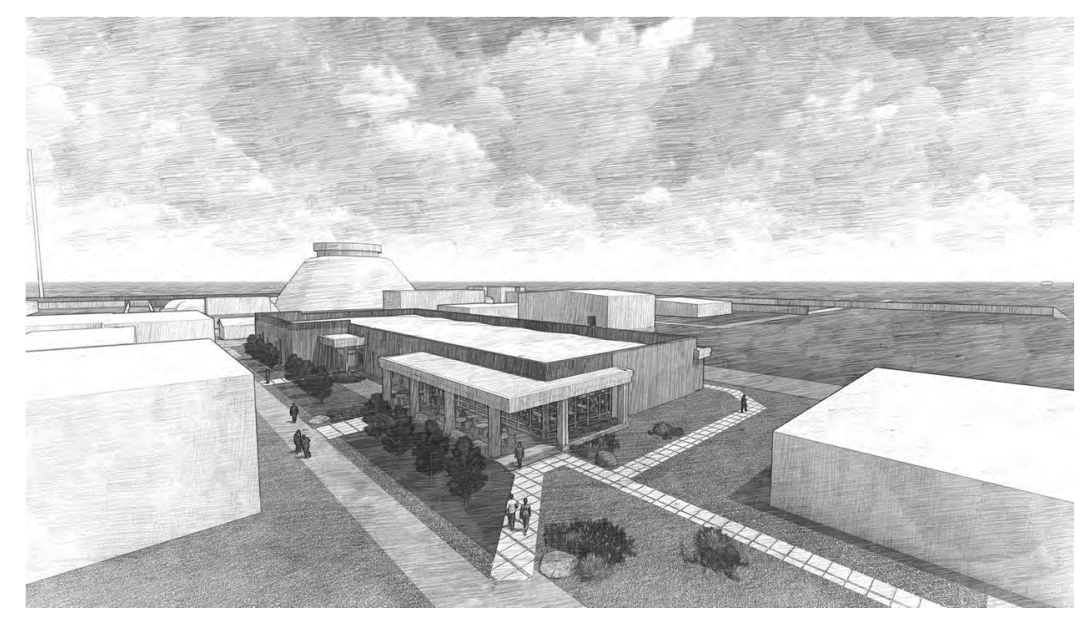




\subsubsection{MFC Security Building}

\section{Description}

A new security building to house Safeguards and Security personnel will be constructed at MFC to replace MFC 714. The replacement building, in concept, will be approximately 11,000 square feet and be constructed on the same footprint as MFC 714 which will be demolished and removed.

\section{Benefits}

The MFC Security Building (MFC 714) is a modular office building acquired in 1977. It is significantly beyond design life and needs to be replaced with more modern and functional infrastructure.

\section{Facility Risk}

The degraded condition of MFC 714 increases risk to facility availability. In the event of a major system failure security personnel operations at MFC would be significantly impacted. Significant investments into facility upgrades to an aging "temporary" modular facility do not make economic sense given the design life of the original structure.

The current condition of this aging facility does not adequately support security personnel, cannot support the staff needed to enable an expanded NRIC mission and, does not meet the goal of a world class campus.

Estimated Cost: This facility is anticipated to be funded with NE Safeguards \& Security funding. This facility is pre-conceptual, project authorization is dependent upon FY-20 appropriations funding and no cost estimates have been developed at this stage.

\section{Status}

Pre-conceptual. Mission need planned for FY-20. 


\subsubsection{MFC Analytical Laboratory Refurbishment/Expansion}

\section{Description}

The AL was constructed in the late 1950s and has been operational since that time. The facility was expanded in the 1970s to add sodium chemistry and nondestructive analysis capabilities. There was a major refurbishment of the hot cells in the early 1990s. Since 2015 a concentrated effort to ensure the AL maintains its ability to support the nuclear mission of INL has initiated. Throughout its history, the AL has been primarily focused on providing chemical and isotopic analyses in support of experimental programs. In addition, the AL supports the analytical infrastructure needs of other MFC facilities. While additional capabilities have been added over the years, the support infrastructure and scientific instrumentation has not kept up with current technology. AL has several single-point failures that could have a major negative impact to MFC's mission if they occurred. While measures can be taken to ensure the AL can meet its near-future commitments by addressing such items as ventilation, the laboratory cannot keep pace with the advancements being made at MFC due to lack of space for state of the art instrumentation, personnel, and the infrastructure needed to support research activities. The AL is almost 60 years old and a feasibility study should be conducted to determine how AL can best be modernized to effectively meet the current and projected expanded mission.

\section{Benefits}

Growing test bed needs will continue to impact mission support operations and limit efficient response to these needs. Given its current infrastructure and space limitations, AL will be unable to address the needs associated with its position as a central part of the DOE-NE test bed and future growth associated with capabilities at MFC unless its analytical capabilities and infrastructure are expanded. Expanded footprint coupled with re-purposing and refurbishment enables AL to incorporate modern infrastructure technologies and install state-of-the-art analytical capabilities that would address upcoming mission needs while attracting world class talent and users.

\section{Facility Risks}

A recapitalization program has been implemented to ensure the laboratory is able to meet its near-term mission by addressing critical infrastructure needs. This proposed effort addresses several current potential single-point failures and alleviates the need to continue in a high-maintenance mode using scavenged and harvested parts. It also lessens the facility reliability risks associated with single-point failures and production bottlenecks that jeopardize the production and efficiency of MFC. However, it does not expand the facility footprint to support additional analytical capability to meet anticipated advances in the nuclear mission. The AL footprint will need to grow to support expanded NRIC capabilities.

Estimated Cost/Status: AL HVAC upgrades and laboratory refurbishment commenced in FY-18 with the first phase of AL HVAC work concluding in FY-20. Class V estimate dated October 9, 2018 range is \$10M-\$15M.Footprint expansion is pre-conceptual and no cost estimates have been developed at this stage. 


\subsubsection{Engineering Scale Reactor Fuels Fabrication Laboratory}

\section{Description}

The Reactor Fuels Fabrication Laboratory will provide a reconfigurable, long-term solution for meeting DOE, small business, and commercial needs for manufacturing demonstration-scale quantities of fuel for licensing in current and advanced reactors. This supports the concept of working alongside industry as part of the NRIC test bed.

\section{Benefits}

An important part of reducing the fuel development time for commercial fuel deployment is the ability to rapidly fabricate large enough quantities of fuel to validate fabrication techniques as well as have enough fuel to fully analyze performance. A new engineering-scale fuel fabrication facility will be needed to allow demonstration of new fuel systems. Demonstration articles must be fabricated using prototypic fabrication processes that produce fuel with reproducible characteristics; doing otherwise confounds the technical understanding of fuel response and makes transitioning from research to development to licensing difficult, because fuel performance data cannot be correlated to fabrication processes and/or microstructure. Significant investment is being made in advanced and rapid fabrication capabilities in industries with regulatory and risk profiles similar to the nuclear industry, including the aviation industry.

Currently the NRC licensed nuclear power industry is regulated to less than $5 \%$ enriched uranium and is only licensed for commercial reactor uranium oxide fuels. The facilities within the DOE complex are currently limited to research quantities of materials, generally less than one kilogram. There is a gap in capabilities for fuel fabrication in the United States for fabrication of test-bed or engineering scale quantities $(2-100 \mathrm{~kg})$ of fuel focused on demonstration-scale quantities of fuel. To fill this gap requires a flexible and reconfigurable hazard category II fuel fabrication facility within the DOE complex that can handle large quantities of nuclear materials with no enrichment limitations. This facility would allow the fabrication of lead test rods, lead test assemblies, micro reactor cores and the demonstration of new fabrication processes using many kilograms of material.

In addition to the direct fabrication capability, an important aspect of this study is to evaluate the extent of the QA needed in the facility to foster reduced overall time required to produce a fully inspected fuel product. A critical quality component to nuclear fuel is elemental and isotopic analyses; as a result, this study needs to strongly evaluate the need for a fresh fuel analytical laboratory that may be included as a part of this facility.

\section{Facility Risk}

There is a gap in flexible capabilities for engineering scale fuel fabrication in the United States at the $2-100 \mathrm{~kg}$ demonstration level and variable enrichment, incorporating potential advanced fuel fabrication and manufacturing technologies. Addressing this gap is critical to ensure that advanced reactor technology is able to move up the technology readiness ladder from basic research through demonstration.

Estimated Cost: This facility is preconceptual and no cost estimates are available at this stage.

Status: This facility is in the conceptual stage and mission need has not been approved.

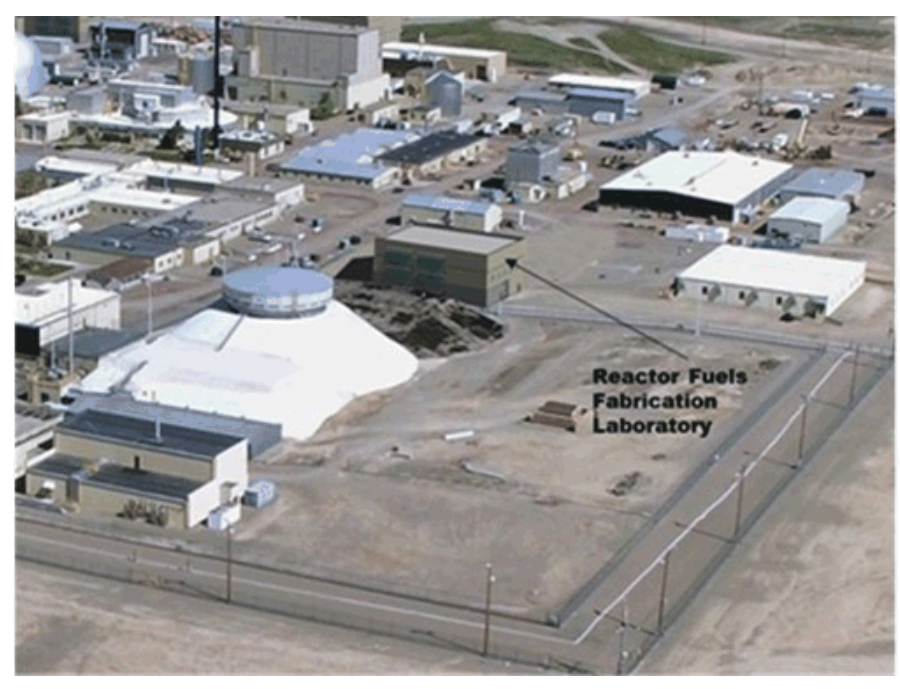




\subsection{Nuclear Research Support Infrastructure Refurbishment and Replacement}

Plant health investments are the investments needed in the nuclear and radiological facilities that directly support the research at MFC. Investments are needed in other crosscutting infrastructure areas to ensure they remain reliable and capable of supporting the research mission and the anticipated growth of the test bed. As the test bed matures, and use of these facilities and their current and anticipated future nuclear RD\&D capabilities grow, additional investments beyond the plant health of the nuclear research facilities are needed to maintain facility reliability and availability to support increasing RD\&D needs.

Additional areas being addressed include:

- Communication upgrades such as fiber optic internet cabling, high-speed wire cabling, and secure wireless internet systems

- Data collection and transmission networks

- Private Facility Control Network (PFCN) cyber security upgrades

- Backup power modernization and consolidation

- Newly generated waste treatment, storage, and disposal (TSDF) capability upgrades

- Underground utilities and support systems (pneumatic sample transfer system, steam, water, liquid waste, etc.) needed to support increased use and throughput

- Electrical distribution upgrades (e.g., switchgear replacement, transmission upgrades, etc.).

MFC is currently evaluating and planning activities in the areas listed above. Specific scope is being authorized and executed as funding allows. Scope is evaluated and prioritized in conjunction with the overall plant health process. This area is executed as individual efforts or as specific campaigns addressing the overarching issues identified above or other emergent issues. 


\subsection{Repurposing Existing MFC Facilities to Support Growth of the Test Bed}

MFC is evaluating existing facilities within the existing campus footprint and determining if they can be repurposed. Repurposing existing MFC space can be a viable alternative to investing in new infrastructure if a new mission for these facilities can be economically established within existing footprint. Several candidate facilities are currently in execution and others are being investigated for repurposing. Actual execution of activities to repurpose these are dependent upon available funding and emergent mission need. Examples of existing footprint that might be converted to support new mission areas include:

- Selected area within the nuclear facilities. The DOE-EM contractor is supporting the laboratory by removing large out-of-service and sometimes contaminated equipment and systems within existing nuclear and radiological facilities. This creates additional foot print to support research activities and enable judicious use of current assets. Three areas are currently funded and in progress. These include:

- Removal of out-of-service control consoles and abandoned conductors within the ZPPR control room

- Removal of the Waste Characterization Glovebox and support equipment from FMF

- Removal of the Development Glovebox located in FASB

- Other candidate areas for EM funded footprint repurposing are being evaluated and dependent upon additional funding. Some of these candidate areas include:

- Removal of tanks and ancillary equipment from the Radioactive Liquid Waste Treatment Facility. A replacement system is being designed and installed elsewhere as part of overall Plant Health efforts

- Removal of the Argonne Fast Source Reactor Structure located within EML

- Removal of systems within FCF including the Inner Building Cask and gloveboxes inside Room 20.

- The EBR-II dome. Ownership of this asset has been transferred back from DOE-EM to DOE-NE at the beginning of FY-19. This facility was placed in cold standby by the EM contractor with plans for future D\&D. It includes the concrete containment dome for the EBR-II reactor which has been decommissioned and removed. This offers approximately $12,000 \mathrm{ft}^{2}$ of internal floor space that is available to support new missions after it is returned to an operational status. Currently limited maintenance type activities are being planned for execution in FY-19 and full repurposing is being evaluated against emergent mission needs.

- MFC-768 Power Plant. This is the original power plant structure that supported the EBR-II reactor and is approximately $51,000 \mathrm{ft}^{2}$. This multi-story facility currently houses some of the electrical infrastructure for MFC and also includes office and lab space. Some mock-up activities are also housed inside. This area has yet to be evaluated in detail but there is a lot of potential to develop office and lab space within the existing footprint.

- Work is currently underway to replace back-up generators near the North Radiography Station in HFEF, remove legacy equipment no longer used, and restore some of the original operability of the elevator and other control systems. This will provide critical additional footprint to expand neutron radiography capabilities such as digital radiography.

- The MFC-752 cafeteria will no longer be needed to support food services after the new multi-purpose office building is completed. This will provide additional footprint available for repurposing. Future use of this available space has not yet been determined. 


\subsection{Laboratory Investments in MFC General Use Infrastructure}

\subsubsection{MFC General Use Infrastructure}

MFC Facility Operations are the hub of DOE-NE's test bed. The U\&IS Group (balance-of-plant), is the hub of MFC facility support operations. U\&IS Group's operations, maintenance, and subcontractoroversight activities are associated with:

- Directly and indirectly funded infrastructure efforts such as updating or refurbishing existing support facilities and their associated structures, systems, and components (e.g., structural, electrical, or heating, ventilation, and air-conditioning (HVAC)-related activities), and efforts such as legacy material disposition

- Laboratory-funded investments for general-use buildings, structures, and support infrastructure. Examples here are building roofs, skins, interiors, electrical and HVAC, pavement and sidewalks, landscaping, lighting replacement, and other sustainability efforts, as well expansion activities.

The U\&IS Group is responsible for operation and maintenance (O\&M) of MFC support structures (mostly administrative buildings) and BOP utilities. The bulk of administrative-building inhabitants are employed in cross-cutting roles associated with Nuclear- and Radiological-Facility operations.

The laboratory invests every year in maintaining the general use infrastructure across the INL. Additional laboratory investment in MFC general use areas will support ensuring MFC has a reliable infrastructure to support the NE test bed and demonstration platform concepts incorporated in GAIN. Much of the support infrastructure inside the MFC fences is the original structures and systems installed many decades ago and well beyond their intended service lives. Additional support infrastructure will be needed to enable the increasing mission work being executed at MFC as well as the diverse new activities anticipated. These capabilities will extend the ability to support broader technology readiness levels. Identification and prioritization of investments is dynamic due to changing technology priorities.

\subsubsection{General Infrastructure Examples}

As stated above more detailed planning is necessary to develop a comprehensive prioritized plan. Areas being evaluated include:

\subsubsection{MFC Parking Lot Refurbishment}

\section{Description}

Increases in mission scope and associated employee growth at MFC has increased the need for more parking access at MFC. The existing parking lot has become insufficient. Much of the parking is now on gravel area adjacent to the pavement and a refurbished parking lot will include these areas.

\section{Benefits}

A "state of the art" parking lot will increase parking space and greatly increase safe employee transit to and from their transportation source (buses, personal and government vehicles, and commercial vehicles.

\section{Risks}

Roughly $30 \%$ of current parking occurs on gravel. These gravel surfaces are not marked, are lit with temporary lighting, and are challenging to adequately perform snow removal from in the winter. The uneven surfaces cause water pooling, and when frozen, very slippery conditions under the snow.

Estimated Cost: The parking lot is entering very early planning and is still pre-conceptual and no cost estimates are available at this stage.

Status: Conceptual stage 


\subsubsection{MFC Front Entrance Improvements}

\section{Description}

This effort will replace the current chain link and barbed wire front entry into MFC with modern "securiscaping" eliminating the dated and imposing military look to the entrance of MFC. This will include replacement of fencing with more modern barriers seen around other secure facilities such as concrete planter barriers and more decorative style barriers such as the modern ornamental type fencing seen around the entrance to FMF.

\section{Benefits}

More modern commercial designs to secure the MFC front entry will provide a much more modern research facility oriented look to the test bed and still maintain critical secure access control.

\section{Risks/Estimated Costs/Status}

This effort is in the conceptual developmental stage and more details will be provided as planning proceeds.

\subsubsection{Other General Areas Being Evaluated}

- Facility upgrades to enhance the appearance of MFC facilities such as adding façade exteriors to selected buildings, updated entrances, etc.

- Site electrical transmission upgrades and refurbishment to bring additional power needed for new capabilities and sustainment of the existing capabilities. This includes local utility upgrades, inter-site electrical transmission loops/corridors

- Increased high performance computing capabilities to support advanced modeling and analysis

- Site-wide wireless internet capability

- Multi-programmatic use facility re-purposing

- Roads, grounds, and general transportation refurbishment and upgrades

- Office space refurbishment and replacement

- Roofs and facility exteriors

- Telecommunications modernization (e.g., high speed, broad-band communication between MFC and the outside world).

General use areas may also be included as parts of wider direct funded "campaigns" as DOE work authorization dictates.

\subsubsection{General Use Capital Investments}

Some out-year general use investments will be necessary to support NE test bed development and maturation at MFC. This includes investments in general use facilities across MFC and includes multiprogrammatic use facilities such as support facilities at the TREAT complex. While these have not all been identified, examples are given below: 


\subsubsection{Heavy Equipment Services and Maintenance Building}

\section{Description}

The MFC Plant Services Building (MFC-753) was first constructed in 1961 and is located near the center of the expanding MFC research corridor. MFC proposes to open up the research corridor to reflect a more open campus functionality by relocating the heavy equipment services function and many of the maintenance support functions to the NE quadrant of the complex.

\section{Benefits}

This facility creates more space in and around the research corridor to support test bed growth, reduces pedestrian interaction with heavy equipment movement, and recapitalizes aging infrastructure eliminating the end-of-life maintenance issues associated with it. This supports the campus vision of collocating industrial functions to the NE quadrant of MFC, separating them from the research corridor areas and freeing up campus space in the research corridor for test bed growth.

\section{Facility Risks}

More heavy equipment demands will be placed on MFC as the test bed grows and nuclear energy technology demonstrations and capabilities mature. More needs for the use of heavy equipment is anticipated, which will also increase interactions of equipment movement and research staff working in a collocated area. An aging test bed support infrastructure will impact test bed growth as needs grow and support availability is impacted from outdated beyonddesign-life support capabilities.

Estimated Cost: This facility is pre-conceptual and no cost estimates are available at this stage.

Status: Pre-conceptual

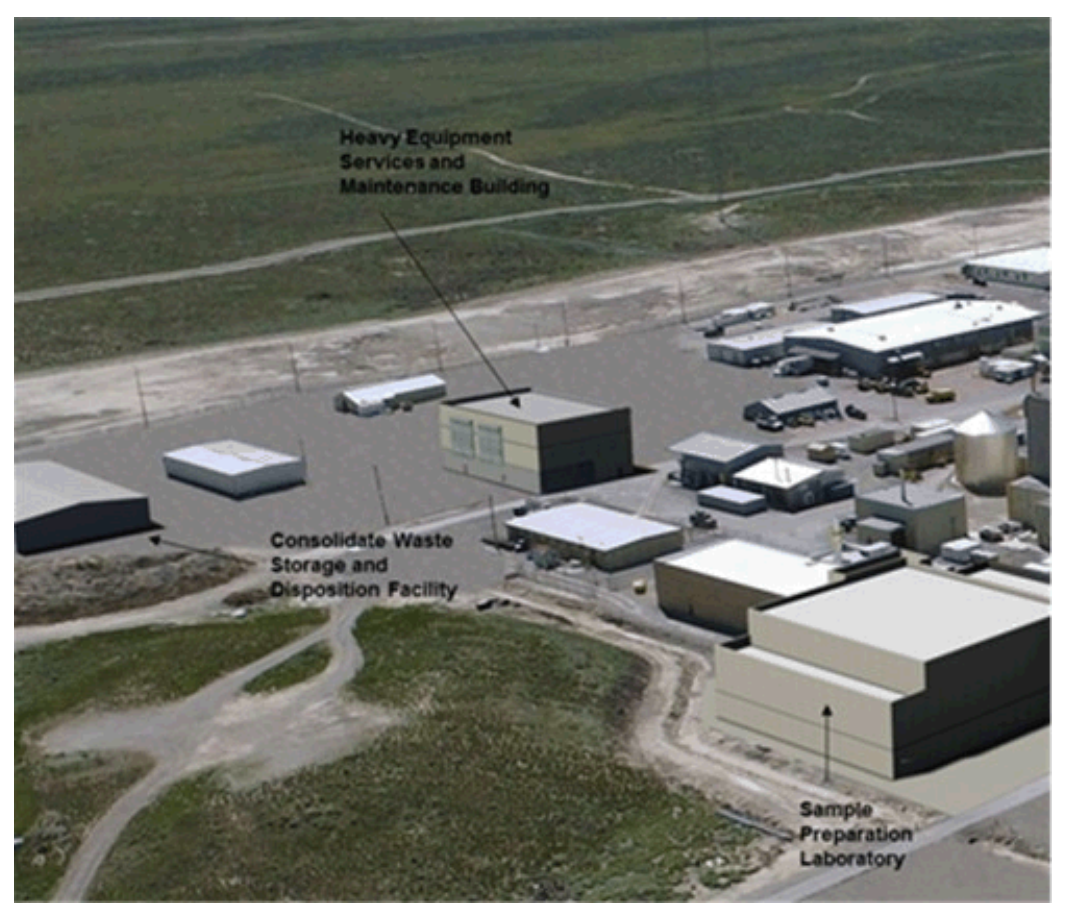




\subsubsection{MFC Consolidated Waste Management, Disposition, and Cask Management Facility}

\section{Description}

The current waste management capabilities of the Sodium Components Maintenance Shop (SCMS) are limited and do not support an effective overall waste management and disposition capability. There is also no facility that can effectively manage cask storage and maintenance. The MFC vision includes a new waste management, disposition, and cask management facility to be located in the NE industrial area of MFC. MFC needs this capability to provide a foundation for an effective strategy to address legacy materials and the anticipated growth in newly generated waste streams resulting from increased and varied RD\&D activities. This will provide a capability to more effectively consolidate, store, and stage waste and legacy materials and prepare this material for offsite disposition reducing the environmental liability at MFC. This building will have limited treatment capabilities and be RCRA permitted similar to SCMS.

\section{Benefits}

This facility reduces risk by reducing the footprint of outdoor storage of material and optimize cask management activities. This aligns with the vision of the research corridor expanding into the NW portion of the campus with industrial functions located in the NE quadrant.

\section{Facility Risks}

MFC must meet the growing waste management demands that will be associated the NE test bed. This facility is necessary to support consolidation of waste management activities from across the test bed, open up more campus space at MFC from this consolidation as well as addressing legacy materials, and ensure that MFC has a consolidated capability to address current and future growth in waste management needs.

Estimated Cost: This facility is pre-conceptual and no cost estimates are available at this stage.

Status: Pre-conceptual

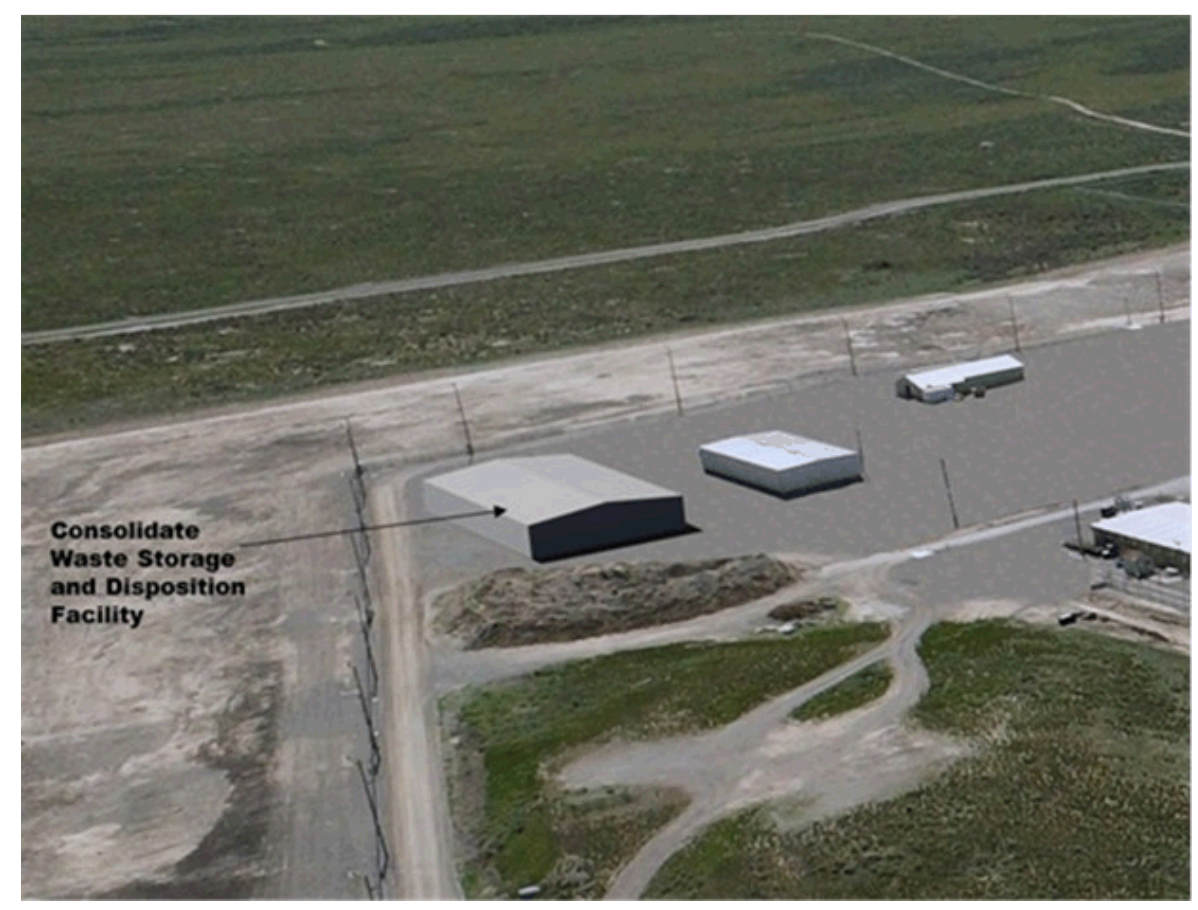




\subsubsection{TREAT Control Room and Support Complex}

\section{Description}

The transient testing facilities at MFC provide multi-programmatic support to an array of users from across the US and internationally. TREAT began operations in 1959 and, as with much of MFC, the infrastructure is antiquated and does not effectively support modern-day operations at a world class research facility. Conceptual planning is ongoing to provide modern support facilities capable of housing staff and hosting visitors in an environment that supports world-class R\&D collaboration and operations.

This effort refurbishes MFC-721, the TREAT office building and constructs an additional support annex to this facility. The addition to MFC-721 will include new offices, rest rooms, and collaboration space. A new septic system and parking areas are also included.

\section{Benefits}

MFC-721 was constructed in 1958. The infrastructure including the septic system, has not been substantially updated since then. TREAT provides a unique and growing transient testing capability in the US and plays a pivotal role in the NE test bed and demonstration platform. Since re-start, the role of TREAT and the burgeoning interest in fuels testing has led to an ever increasing scope of experiments and customers. This has led to challenges in providing adequate workspace for TREAT staff, as well as experiment personnel. This upgrade provides needed expansion for direct support of daily operations and experiments, as well as a more appropriate esthetic for a world-class modern office building and "storefront" to the TREAT complex.

\section{Facility Risks}

The present occupancy for MFC-721 is not adequate to hold the operations and support staff needed to efficiently enable RD\&D at TREAT. Despite efforts to maximize efficient use of the present footprint, staff is currently overcrowded and doubled or sometimes tripled up in offices. There is no room to house users or to effectively manage, support, and collocate experiment teams with operations and technical staff. With the increasing experiment workload and requisite addition need, the present situation will only worsen in the future.

Estimated Cost: This facility is pre-conceptual and no current cost estimates are available at this stage.

Status: Conceptual, no current time frame for construction.

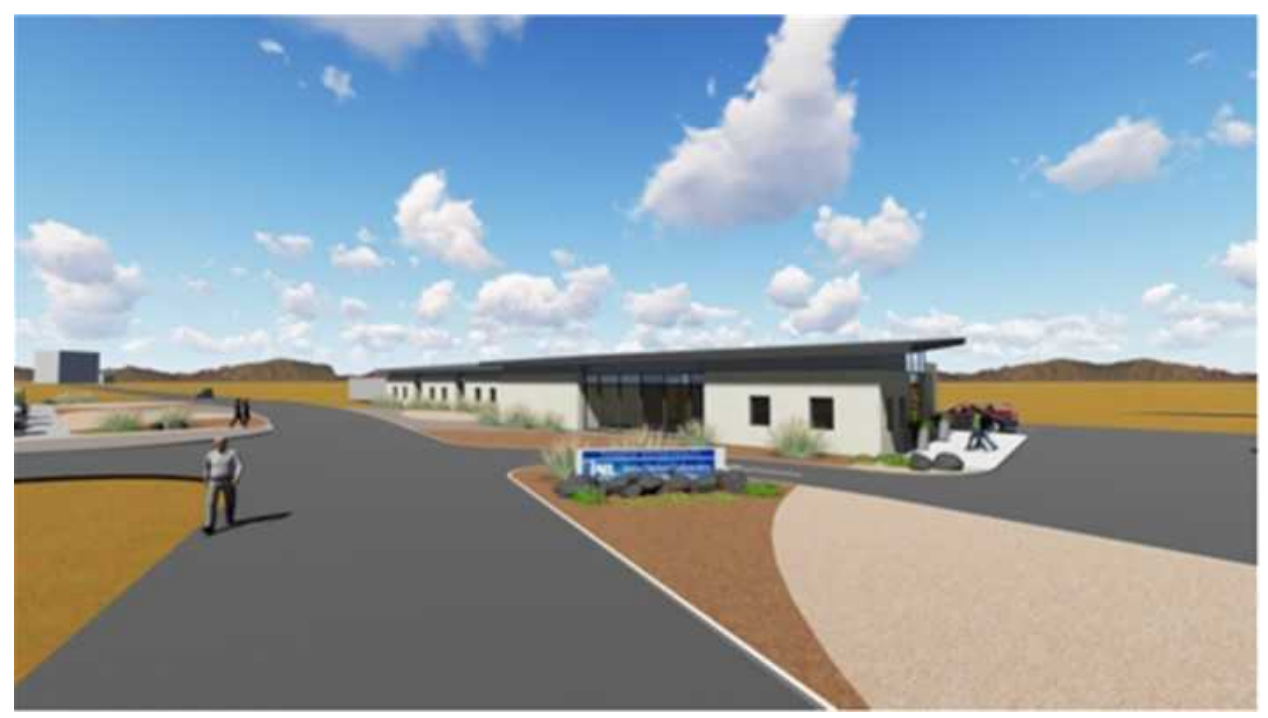




\subsubsection{HFEF Research Collaboration Area}

\section{Description}

The Hot Fuel Examination Facility (HFEF) is used for remote, shielded handling, characterization, and processing of highly radioactive components and materials, such as irradiated fuels and reactor components and fuel treatment waste materials. In-cell equipment is specially designed and qualified for in-cell use to assure high reliability and suitability for remote operation and maintenance. Such equipment requires continual evaluation, maintenance, and (occasionally) modification to improve performance. Each in-cell system is assigned to a system engineer that oversees performance of the system and responds to any issues or enhancement needs by engaging maintenance personnel, design engineers, and others with needed skills. The variety of activities simultaneously underway in HFEF has grown considerably in the recent decade as the nature of missions served has become increasingly diverse and as productivity have improved. For that reason, HFEF staff necessarily continues to grow, with increasing numbers of operations personnel, systems engineers, and facility engineers. Currently, there is no space remaining in the building that can be repurposed as meeting and work space, so there is no space available to accommodate visiting researchers or to locate system and facility engineers needing quick access to the operating areas.

This new construction will annex the existing administrative area of the HFEF building with additional space for a meeting room, a collaboration space, offices, turnaround work stations, and rest rooms.

\section{Benefits}

The additional space will provide accommodations for visiting researchers and office space for engineers needed to ensure HFEF is utilized to the maximum extent possible.

\section{Facility Risks}

If this additional space is not provided, then resident and visiting personnel will not have convenient access to the facility to monitor experiments or to ensure the facility and equipment are operating and maintained as needed.

Estimated Cost: This building addition is pre-conceptual and no cost estimate is available at this stage.

Status: Pre-conceptual 
MFC FIVE-YEAR INVESTMENT STRATEGY 


\section{Appendix A}

\section{Detailed Descriptions of Plant Health Activities}


MFC FIVE-YEAR INVESTMENT STRATEGY

Appendix A

Detailed Descriptions of Plant Health Activities 


\section{Replace or Upgrade the AL HVAC System}

\section{Description}

AL suspect exhaust fans and HEPA banks are operating at or near (within a few percent) maximum capacity at all times with the current configuration. Some existing equipment including HEPA banks are degraded and shut down or cannot be connected because the suspect exhaust system cannot support the ventilation requirements. The result is an inability to be efficient in our processes and creates delays in sample processing. General laboratory area airflow direction and pressure differentials are difficult to maintain as desired to limit migration from zones of higher to lower potential contamination (hot cell pressure differentials are maintained). AL's mission is continuing to grow and evolve with an anticipated increase in throughput and precision and sensitivity for radiochemical measurements. Reheat/Room heaters intended to maintain lab temperatures within a tighter band are currently steam heaters, which cannot provide the precision and control needed for current technology instrumentation.

The HFEF pressure and temperature $(\mathrm{P} / \mathrm{T})$ system is used to control main cell atmospheric conditions. A portion of the $\mathrm{P} / \mathrm{T}$ system was replaced in the 2016 major maintenance outage. The next phase is updating the purification system which controls the cell oxygen and moisture content. Aging components in the system have begun to cause significant maintenance issues, requiring increased costs in personnel time and replacement parts.

\section{Benefit}

Control of differential pressure within the AL is currently extremely difficult with the analog equipment installed. Research activities are regularly suspended due to air flow concerns. This upgrade will provide digital pressure differential control technology for control of building ventilation, enhancing safety for personnel within the facility and improving efficiency of research activities.

As uncertainty of measurements gets reduced, the data produced gets more accurate. This also Increases availability of laboratory due to fewer ventilation-failure induced shutdowns. Improved flow and pressure control reduces the risk of contamination migration.

This effort increases reliability and operational safety of the HFEF argon cell purification system control which improves operational efficiency (reduced operational burden to maintain desired atmosphere and improved HFEF main cell atmosphere control to meet mission needs.

\section{Facility Risk}

Control of building air flow from areas of least contamination to areas of higher contamination is a fundamental principle for protecting workers in nuclear facilities. The current AL ventilation DP control is analog and segmented in approach. AL staff is required to regularly suspend research activities and adjust the ventilation system to achieve minimum air flows. The current system limits the addition of scientific capability within the AL as new instrumentation has a negative impact by exceeding the limits of the current HVAC system. This upgrade will provide enhanced air flows and minimize research interruptions. Failure of key blowers, dampers, or control system components would result in several weeks down time for key AL lab spaces.

ROM Cost Estimate: $\$ 10 \mathrm{M}$. 


\section{AL Lab B-103 Refurbishment}

\section{Description}

The scope of work includes the purchase and installation of replacement fume hoods and high efficiency particulate air (HEPA) filter housings with filters to allow for the return-to-service of two hoods located in Room B-103. The existing fume hoods have been out-of-service (OOS) for several years as a result of corrosion of the existing HEPA housings. Additionally, the steam heater will be replaced with an electric duct heater and new pressure and air flow controls will be installed.

\section{Benefit}

The MFC-752 Analytical Laboratory (AL) was constructed in the late 1950s and has been operational since that time. The facility was expanded in the 1970s to add sodium chemistry and nondestructive analysis capabilities. There was a major refurbishment of the hot cells in the early 1990s. Since that time, however, there has been no cohesive, concentrated effort to ensure the AL maintains its ability to support the nuclear mission of INL. With ever increasing programmatic demand, near-term investment is required to ensure programmatic commitments are met. This project will re-establish needed functionality in Room B-103 to support continued programmatic needs. This scope is part of the scope envisioned in Item No. 3 on the Fiscal Year (FY) 2018 MFC Five-Year Plan Investment - Facility Reliability Proposed Scope list, dated May 2018.

\section{Facility Risk}

Without the upgrades, the hoods will remain out of service. The work is part of the overall plan of the facility to support increasing programmatic needs.

ROM Cost Estimate: $\$ 1.2 \mathrm{M}$ 


\section{AFF HVAC Modifications}

\section{Description}

Similar to the prior CESB-to-EFF HVAC modifications, this effort will design, procure, and install a HEPA-filtered building HVAC system in the Advanced Fuels Facility (MFC-784).

\section{Benefit}

The current facility has no air conditioning and gets extremely uncomfortable to work in during the afternoons in the three summer months. The HEPA-filtered building HVAC system will permit installation of radiological hoods and large radiological equipment with hooded enclosures (e.g., mill, lathe, grinder, arc melter, etc.) within a Contamination Area, significantly increasing the nuclear fuel manufacturing equipment that can be installed in the available facility footprint.

\section{Facility Risk}

If INL does not install a HEPA-filtered building HVAC system in MFC-784, then radiological hoods and large radiological equipment with hooded enclosures cannot be installed in the available facility footprint. The INL will miss or delay opportunities to meet RD\&D test bed and demonstration platform objectives, for external lab impact, and for funded RD\&D scope. The facility will also continue to have a very hot working environment for three months of the year limiting the amount of time personnel can reasonably perform continuous work.

ROM Cost Estimate: \$3M. 


\section{Manipulator Replacement Campaign in HFEF, FCF, and AL}

\section{Description}

This project procures a new manipulator system for replacement of the obsolete manipulators in HFEF, FCF and AL and commences an extended manipulator replacement campaign. Replacement manipulators are not currently available and will need to be developed by the supplier. To fully test manipulator capability prior to implementation, two complete units need are being procured with additional slave arms of varying length to simulate the implementation in cell. The concept is a modular manipulator with a standard seal tube. Heavy duty master/slave and medium duty master/slave would utilize the same seal tube and allow for maximum cell configurability. Additionally, several slave arms of varying length would be balanced to a master configuration to allow in-cell configuration as needed for each work station. This concept would minimize the total number of manipulator arms needed. Scope includes procurement of a set of manipulators for the mockup, testing and evaluation followed by optimization prior to procurement of a complete set of manipulators in each facility. The mockup manipulators will remain for use in qualification of equipment.

\section{Benefit}

This project provides 'like for like replacement' of the aging manipulator fleet. The implementation of manipulators can be scaled back based on funding but should provide one or more operating station replacements per year as funding allows.

\section{Facility Risk}

Current manipulators are obsolete. Spare parts are no longer available from vendor and increased usage is resulting in increased breakage. Many are out-of-service and cannot be repaired. Prototype manipulators are being tested with the vendor now. Delays in completing this campaign adds to the risk that cessation of mission work that could span months at critical hot cell windows if old manipulators fail and impact facility availability.

ROM Cost Estimate: $\$ 17.9 \mathrm{M}$. 


\section{Window Replacement Campaign in HFEF, FCF, and AL}

\section{Description}

Main hot cell windows at HFEF, FCF, and AL use mineral oil to provide clarity between window panes. Several windows have developed mineral oil leaks into the hot cells. HFEF window $1 \mathrm{M}$ is currently leaking approximately 2 gallons per month. Operators currently have to periodically clean up the oil manually. This project involves evaluating the condition of the windows and providing a means to restore the windows to their intended function. This is not considered a standard maintenance item due to the complexity of the repair and the need to breach the hot cell containment in order to implement the repair. This project will include significant interruption of facility availability. Each window replacement will require: fabrication or refurbishment of a replacement A-slab (outer layer of a multi-layer hot cell window unit) with oil collection and management capability, installation of the new/refurbished A-slab, fabrication or refurbishment of replacement window tank unit extracts, and installation of the replacement/refurbished tank unit. There are a total of 3 leaking windows in HFEF, 2 in FCF, and 2 in AL that require replacement.

\section{Benefit}

Mitigates oil leaks by establishing a leak tight A-slab and allowing for periodic draining of accumulated oil between the A and B slabs. It also corrects the source of the oil leak and establishes the original integrity of the system. Additionally, the fabrication of the replacement tank unit minimizes the downtime on the facility with the facility hot and argon filled.

\section{Facility Risk}

The hot cells are aging and additional window failures are anticipated. Failure to provide the additional window replacements may jeopardize hot cell operations due to the extensive planning and lead time associated with the evolution. A catastrophic window seal failure would cause unacceptable mission impacts on the order of months to over a year.

ROM Cost Estimate: $\$ 25.5 \mathrm{M}$. 


\section{HFEF Argon Cell Temperature and Pressure Controls}

\section{Description}

The HFEF pressure and temperature $(\mathrm{P} / \mathrm{T})$ system is used to control main cell atmospheric conditions. A portion of the $\mathrm{P} / \mathrm{T}$ system was replaced in the 2016 major maintenance outage. The next phase is updating the purification system which controls the cell oxygen and moisture content.

\section{Benefit}

Increased reliability and operational safety of the HFEF argon cell purification system control. Improved operational efficiency (reduced operational burden to maintain desired atmosphere. Improved HFEF main cell atmosphere control to meet mission needs.

\section{Facility Risk}

Aging components in the system have begun to cause significant maintenance issues, requiring increased costs in personnel time and replacement parts. The major risk to the facility involves a component failure that requires feed and bleed as the only method to control oxygen and moisture levels in the cell. This may not meet operational specifications or mission needs for the cell atmosphere and would result in delays while design and repair efforts are pursued. This may affect operational milestones and mission commitments.

ROM Cost Estimate: $\$ 1.5 \mathrm{M}$ 


\section{Replace the Criticality Alarm System (CAS) in FMF and ZPPR}

\section{Description}

Replace the existing Criticality Alarm System (CAS) with a new and equivalent system. CAS components are many years past their intended design life and spares are no longer available. These facilities have each experienced one to two week outages due to failed detectors. Repair was accomplished by scavenging detectors from other out of service alarm systems.

\section{Benefit}

Installation of a state-of-the-art system will ensure maximum facility availability for mission work and readily available spare parts. Purchasing both systems together resulted in a net cost savings of over \$1M.

\section{Facility Risk}

Failure to upgrade the CAS will result in the eventual failure of detectors or other irreplaceable components resulting in unacceptable facility downtime of up to 6-9 months as a replacement system is fabricated and installed.

ROM Cost Estimate: $\$ 2 \mathrm{M}$. 


\section{HFEF Facility Out-Of-Cell 40-Ton High Bay Crane}

\section{Description}

The 40-ton high bay crane is a traveling bridge crane that traverses the full length and width of the high bay. The crane is used to load and offload the majority of casks used to transport research specimens to and from the facility. Prior to installation in the HFEF, the 40-ton high-bay crane was in service at other INL locations since 1955. The crane was installed in HFEF during initial construction and has now been in service for over 60 years. The crane exhibits a variety of issues related to age that now requires upgrading. These issues include rails and trucks wearing out, trucks climbing up on rails due to crabbing of the trolley, and an obsolete control system failing frequently.

\section{Benefit}

The benefits related to repair of the 40-ton crane is significantly increased reliability as well as proper operation and operating efficiency.

\section{Facility Risk}

The facility risk (if this repair is not completed expeditiously) is the complete halt to HFEF operations and any HFEF related program work since the crane is vital in processing casks and waste containers in and out of the facility. It is estimated that a work cessation due to crane failure could span greater than a year as a replacement is obtained and installed.

ROM Cost Estimate: $\$ 3.1 \mathrm{M}$. 


\section{HFEF/IMCL Supplied Argon System Replacement}

\section{Description}

The existing HFEF argon compressors are obsolete. The existing compressors are old (1950s vintage) and obsolete; direct replacements are not available. HFEF is operating on compressor \#2, compressor \#1 is out of service. It is estimated that compressor replacement with a comparable system would take approximately 12-18 months and would require extensive modification to HFEF. Compressor \#1 failed in 2017 due to an internal water leak. The water damaged the connecting rod seals, efforts to repair the compressor failed. Now when running it raises the oxygen levels significantly in the HFEF main cell. Do to the lack of available spare parts, this compressor cannot be put back into operation. The solution to the failed/failing compressors is to replace this system with a large liquid argon storage tank. The tank will be located north or HFEF. The tank will supply all the loads that is currently carried by the compressor and will also remove portable gas bottles utilized to support various programs that require pure argon blankets, like JFCS. In addition to supplying the compressed argon system the argon tank will replace the current "emergency" argon supply system with one that can actually support the HFEF main cell for an extended period of time. The current system can supply 2000 SCFM to a cell that is 60,000 SCFM.

The system is large enough and will be located in an area that can also be utilized by IMCL to support programmatic work. IMCL has several gloveboxes that would benefit from have an argon atmosphere. Currently IMCL must use portable AR bottles to supply any programmatic need.

\section{Benefit}

The argon tank is a passive system that has no moving components. The removal of moving components greatly reduces failure mechanisms. This reduces the risk to programs in HFEF. Currently if the compressed argon system fails it will stop program work in the containment box, which also effects the METBOX. The failure of the compressors will also make the large equipment lock inoperable, if the large lock is inoperable the HFEF main cell must be placed in the standby mode. Again the lack of moving components will greatly improve reliability of HFEF. The ability to place the "emergency" argon system on the tank eliminates a potential vulnerability and provides a more extensive defense-in-depth system.

\section{Facility Risk}

This reduces the risk to programs in HFEF. Currently if the compressed argon system fails it will stop program work in the containment box, which also effects the METBOX. The failure of the compressors will also make the large equipment lock inoperable, if the large lock is inoperable the HFEF main cell must be placed in the standby mode. Currently if the compressors fail HFEF could be in the standby mode for 3 to 6 months while this modification is made. The operating compressor is due for an extensive rebuild based on hours of operation, if performed there is a potential that the compressor will not be capable of being resealed due to lack a materials or degradation of components. By not performing this maintenance there is an increased risk of compressor failure.

\section{ROM Cost Estimate: \$2M.}




\section{FCF Multi-Function Furnace}

\section{Description}

The electrometallurgical treatment process used to neutralize the sodium component of irradiated EBR-II elements includes a salt distillation step as part of the process. Currently, the 25 year old Cathode Processor $(\mathrm{CP})$ is the only means of performing this salt distillation requirement from uranium dendrite or other process materials in the FCF argon cell. When maintenance needs arise, repairs to this unit must be performed remotely which results in extended treatment process downtime. This is a single point failure that limits process treatment rates. The addition a secondary distillation capability via a new high temperature vacuum atmosphere furnace in the FCF argon cell will enable salt distillation requirements to continue when maintenance occurs on the Cathode Processor and will help to alleviate the bottleneck at this process step associated with higher throughput rates. Additionally, this new furnace will be designed to support expanded missions beyond salt distillation to include cladding hull consolidation, sodium contaminant distillation, as well as uranium consolidation.

\section{Benefit}

Increase in overall treatment system reliability and process rate efficiency, while expanding capability in enhancing uranium product and process waste stream disposition

\section{Facility Risk}

The single point failure associated with the current treatment system limits the rate of treatment. Past operational conditions provided some flexibility to store dendrite on an interim basis until the Cathode Processor was available, however future operating requirements will significantly restrict this capability, resulting in shutting down the process until repairs can be made.

Workload at the CP is increasing, while equipment availability has been decreasing in the recent past due to unplanned component failure related to the age of them.

ROM Cost Estimate: \$6M. 


\section{Radioactive Liquid Waste Treatment Facility Process/Storage Tanks Alternatives Analysis and Replacement}

\section{Description}

RLWTF has four 1000-gallon tanks, one of four tanks has evidence of recent leaks that has not been repaired and the two other tanks have been previously patched. These tanks need to be permanently removed from service and a suitable replacement system will be installed.

\section{Benefit}

The replacement system will utilize commercial products and eliminate RLWTF process equipment O\&M costs. This also reduces radiological risks.

\section{Facility Risk}

Facility risk is reduced by installing a low maintenance alternative to existing RLWTF system. Eliminate consequences of failure of this system that would entail stopping manipulator repairs in HFEF and FCF (as there would be no water reservoir for drain water from manipulator decontamination work). This would rapidly shutdown programmatic work in these hot cells.

ROM Cost Estimate: \$3M. 


\section{HFEF Small Transfer Lock Doors}

\section{Description}

The small transfer lock is used to transfer small materials between the main hot cell and decontamination cell. It is used to support both programmatic and in-cell maintenance. Hinges and sealing surfaces have degraded. These doors maintain argon cell containment control and limit contamination release between the two hot cells. These doors are safety significant.

\section{Benefit}

Small lock door replacement will return the physical hot cell boundary to the original condition. This action minimizes the risk of future material transfer delays due to system inoperability.

\section{Facility Risk}

Failure to perform this work increases the risks to perform material efficient material transfers to support programmatic work. The door repair is a long-lead activity with an estimate of 6-9 months to obtain, modify, and install a replacement.

ROM Cost Estimate: $\$ 600 \mathrm{~K}$. 


\section{HFEF Small and Large Transfer Lock Drive Control System Replacement}

\section{Description}

The large and small lock drive controls are old and prone to failure. This project replaces the existing controls with new modern controls.

\section{Benefit}

Replacement of the drive controls with modern components will increase reliability of lock door operations.

\section{Facility Risk}

Failure to replace the controls would expose program work to increased schedule risk should the locks become inoperable due to control issues.

ROM Cost Estimate: $\$ 500 \mathrm{~K}$. 


\section{HFEF and FCF Electro-Mechanical Manipulator Refurbishment}

\section{Description}

Electro-mechanical manipulators (EMM) perform the majority of material intra-cell transfers to support both programmatic work and maintenance activities associated with in-cell equipment. This equipment is original to the facility and has been maintained on run-to failure basis. As such, the majority of the corrective maintenance centers around the EM carriages and bridge drives motor modules. This task ensures continued maintainability of the EM carriages and bridge drive modules as well as evaluating the bridges through the implementation of viewing equipment to perform remote inspections to identify and perform additional maintenance/upgrades necessary for continued operation.

\section{Benefit}

Operability of the EMM's is directly related to the ability to complete programmatic work. This project will inspect and identify potential problems allowing correction and/or modification in a planned methodology to minimize programmatic impacts.

\section{Facility Risk}

Failure to perform this work can lead to increased failures of the EMs with significant lead times associated with planning, design/fabrication of replacement parts, and implementation. Since, many components on the EMs fabricated specifically for the end use. The delay times could be several months to restore full facility operations.

ROM Cost Estimate: \$2M Annually through FY-23. 


\section{MFC Legacy Materials Disposition}

\section{Description}

Typically, disposition of waste is accomplished as waste is generated; however, past practices in performing mission work did not require disposition waste as it was generated resulting in a buildup of waste in the FCF and HFEF main hot cells. This is considered legacy in that no current programs generated the material. This waste accumulation has reduced the programmatic work space. To support GAIN and other missions, this legacy waste must be removed to provide adequate space for required facility and programmatic upgrades, and new mission-required equipment.

\section{Benefit}

Reduction in the existing quantity of legacy waste currently residing in the HFEF argon cell will increase the amount of useable floor space for installation of new programmatic equipment as well as facilitate transfer of equipment and materials within the cell.

\section{Facility Risk}

Failure to reduce the existing legacy waste backlog will inhibit new equipment installation as well as potentially delay programmatic work due to cell congestion and delays in equipment installation. Operations become severely limited and remote handling mishaps more frequent when waste items are allowed to build up in-cell.

ROM Cost Estimate: $\$ 2 \mathrm{M}$ in FY-18 and $\$ 500 \mathrm{~K}$ per year after to support a multi-year campaign. 


\section{New SCRAPE Cathode Module for FCF Electrorefiner}

\section{Description}

The electrorefiners in FCF are used to separate the EBR-II used fuel and irradiated blanket materials into individual components as part of the treatment process to neutralize the sodium used in constructing the elements. As part of the process, the separated uranium is recovered on a cathode mandrel and removed from the vessel for potential re-use in other nuclear fuel cycle applications, including high assay low enriched uranium for proposed fast spectrum research reactors. Removal of the cathode with accumulated uranium dendrite is time consuming and occurs 4 to 6 times (on average) during a treatment batch. Implementation of the scraped cathode concept is intended to reduce the frequency of cathode withdrawal via accumulation of uranium dendrite in a co-located product collector and use of an integrated compaction plate to increase the amount of uranium dendrite removed from the electrorefiner each time the cathode is withdrawn.

\section{Benefit}

Increase in overall treatment system reliability and process rate efficiency.

\section{Facility Risk}

The task of removing the electrode assembly and connected cathode mandrel from the ER is one of the more time consuming aspects of the treatment process. The frequency of handling electrode assemblies to remove the cathode is manipulator intensive and disruptive to processes occurring in the adjoining workstations, thus concepts that could lead to a reduction in the frequency with which this operation is conducted could yield significant overall efficiencies to the treatment process.

ROM Cost Estimate: $\$ 2.5 \mathrm{M}$. 


\section{FCF Integration of Bottle Inspection with Wire Removal}

\section{Description}

Currently inspection of EBR-II fuel bottles for the presence of moisture is conducted at window 10 in the FCF argon cell. This is several workstations away from the chopping function which occurs at window 2. Movement of uninspected bottles from the air cell to window 10, and the return of inspected elements back to window 2 for chopping introduces a number of handling steps which contribute to treatment process inefficiency. Additionally, removal of wires at the same work station where chopping occurs accounts for a significant amount of the time that the fuel spends at that work station. If wire removal and cassette loading occurred in conjunction with bottle/element inspection additional handling could be eliminated.

\section{Benefit}

Elimination of lengthy in-cell transfers through multiple workstations, coupled with consolidation of the element/bottle inspection and spacing wire removal functions will increase overall treatment system reliability and process rate efficiency.

\section{Facility Risk}

Requiring elements and bottles to travel through the primary treatment workstations (MK-IV ER, CP, \& $\mathrm{CF}$ ) creates challenges in making sure the transfer paths are clear and introduces the potential for delays in the treatment process while waiting for the pathway to clear. Additionally, consolidation of multiple fuel subassemblies at window 2 challenges zone inventory limitations. Thus reduction in the amount of time fuel assemblies spend in this zone due to wire removal will help mitigate this challenge.

ROM Cost Estimate: $\$ 1.5 \mathrm{M}$ 


\section{Replace FCF Facility Control System)}

\section{Description}

The facility and process monitoring and control systems in the Fuel Conditioning Facility (FCF) were designed, constructed, and installed by in-house MFC engineers and technicians. The backbone of these systems consist of three integrated component types. These components are:

1. Programmable Logic Controllers (PLC)

2. Small Logic Controllers (SLC)

3. Operator Control Stations (OCS)

These components were last replaced in the 1990s and are past obsolescence. The old components operate under the Windows XP platform that is no longer supported or maintained by Microsoft. The individual PLCs and SLCs within the systems use modules that are no longer available from the vendor. The vendor is requiring replacement of these older system components with new, up-to-date hardware in order to provide vendor support. Migrating to new hardware involves porting the existing PLC/SLC application software to a modern, vendor supported, operating system. The OCS human machine interface (HMI) was developed using the FIX32 (Supervisory Control and Data Acquisition software system) will not run on platforms running Microsoft Windows' versions newer than XP. Fortunately, the Fix32 HMI software can be converted to a new version, iFIX, that will operate under current Windows operating system platforms (and should be supported for many years to come). All of the components within a system must be upgraded simultaneously to maintain proper system functionality.

As the older components continue to fail in service, the FCF has experienced unscheduled system outages that have delayed facility operations while repairs are made. Replacement of these system components, under crisis management methods, has not proven timely or cost effective. This project will replace the obsolete components, repair or replace the networking backbone of the systems, update all components to run on supported Microsoft Windows operating systems, and do so in a series of scheduled facility outages that will be coordinated with other facility operations and schedules. In this way, high facility reliability and availability can be sustained.

\section{Benefits}

1. Increased facility availability and reliability

2. Network security of systems is reestablished.

3. New hardware will be supported

4. Commercial spare parts readily available

\section{Facility Risk}

The FCF monitoring and control systems have reached end of life. The systems in question provide critical data and control functionality to/from various processes and systems throughout the facility. Equipment failure has had a detrimental impact on FCF's daily operations and overall mission. The impairment caused by the failure of this equipment has resulted in facility outages that have prevented facility activities from being performed (such as EBR-II fuel processing). This equipment must be upgraded in order for FCF to operate through its anticipated life.

ROM Estimated Cost: $\$ 4.8 \mathrm{M}$. 


\section{FMF/ZPPR Roof - Replacement}

\section{Description}

The FMF is covered by an earthen berm that provides shielding for the nuclear material located in the building. The berm is classified as a safety system. A cellular confinement stabilization fabric is placed over this berm and serves as the roof for the building. The existing FMF roof exhibits numerous areas where the fabric anchors have backed out and the rock has fallen below the fabric. The ZPPR fabric roof is at end-of-life and requires replacement. This project will repair the entire berm area and replace the roofing material with a new, similar system. This is needed due to the general amount of deterioration between 2011 and 2013, and the accelerated deterioration in areas where water is able to penetrate (TEV-1979).

\section{Benefit}

The FMF berm serves a safety function as radiological shielding; the depth and material composition are important factors in the shielding calculations. Subsidence that significantly decreases the depth of the berm material will increase the resulting radiation dose. The ZPPR fabric and earthen covering serves a safety function as radiological shielding; the depth and material composition are important factors in the shielding calculations. Subsidence that significantly decreases the depth of the berm material will increase the resulting radiation dose.

\section{Facility Risk}

Roof degradation is significant in places. Infiltration of precipitation during rain events and snow melt are beginning to occur frequently. Infiltrations of water into the facilities can create hazardous conditions and halt operation until it is addressed. This impacts facility availability and required significant labor resources to mitigate.

ROM Cost Estimate: \$6M. 


\section{Analytical Laboratory Lab Room Renovations}

\section{Description}

The Materials and Fuels Complex Analytical Laboratory (AL) provides high-quality processing, analysis and characterization of radiological materials. The AL laboratory rooms house sample preparation and examination equipment and analysis instrumentation. The majority of the lab rooms are located in the Bwing and Sodium wing of the AL. The B-Wing and Sodium Wing were put into service in 1957 and 1969 respectively with little to no updating since being put into service. Damaged asbestos based floor tiles and work surfaces are present in many of the lab rooms. Windows are single-pane with aluminum framing which provide marginal insulation value. Additionally, modern instrumentation detection limits are so low that background radiation levels within some of the rooms interfere with new instrument capabilities. Therefore, laboratory rooms need to be decontaminated and new sample preparation fume hoods and work surfaces need to be installed.

\section{Benefit}

Clean and modern work environment with more efficient equipment and use of lab space will optimize performance of personnel in their workspaces. Updated work areas and equipment will reduce the amount of emergent maintenance required.

\section{Facility Risk}

The conditions can be less than ideal for operating equipment. Inefficient layout of workspaces present challenges for personnel when preparing samples for analysis. Personnel output is reduced both in volume and quality when working environments are not satisfactory. Background levels are interfering with the lower detection limits required by programmatic work and capabilities of current instrumentation being installed in the AL.

ROM Cost Estimate: $\$ 400 \mathrm{~K} / \mathrm{lab}$ room. 


\section{1. - 26. IMCL Efficiencies}

\section{Description}

The Irradiated Materials Characterization Laboratory (IMCL) is the newest nuclear energy research facility at the Idaho National Laboratory's (INL) Materials and Fuels Complex (MFC). This unique 12,000 square foot facility incorporates many features designed to allow researchers to safely and efficiently prepare and conduct microstructural level investigations on materials of construction and nuclear fuels.

Numerous smaller areas for improvement have been identified as work with the ultra-sensitive instruments has begun in earnest. These areas include:

- Optimizing sample transfer capabilities for more effective operations

- Installing a manipulator repair station to avoid having to ship manipulators to other facilities for repair

- Enhancing the communications infrastructure

- Further refinement of the ventilation system to reduce interference with instruments

- Refining the fixed air sampling system to support more effective operations

\section{Benefit}

The benefits of the noise reduction within IMCL will allow for the utilization of the state of the art equipment at their optimum level, increased satisfaction for researchers and visitors to IMCL and increased knowledge for future state of the art building projects at MFC.

\section{Facility Risk}

Continued suboptimal utilization of instrument capabilities and uncomfortable noise level to researchers and visitors to IMCL.

ROM Cost Estimate: $\$ 1.9 \mathrm{M}$. 


\section{Radiation Monitoring Updates}

\section{Description}

Additional radiological control equipment is needed to support facility operations. Multiple facility CAMS and RAMS are obsolete and have reached their EOL. Beta and Alpha CAMS are required to be replaced because the in-service instruments are no longer supported by the manufacturer. The old units are failing at an ever increasing rate. Spares are not available. Other equipment consists of friskers, hand monitors and portable smear counters.

\section{Benefit}

The additional equipment will reduce inefficiencies associated with re-locating portable equipment within many of the RD\&D facilities. In addition, locating this equipment near the point of work will reduce the risk of spreading contamination.

\section{Facility Risk}

Continued inefficiencies locating and moving portable equipment within the laboratory and limiting work activities due to un-availability of radiological equipment.

ROM Cost Estimate: $\$ 3.1 \mathrm{M}$. 


\section{MFC Sitewide Drainage System Upgrade}

\section{Description}

The MFC Sitewide Drainage System is composed of stormwater runoff and industrial wastewater. Stormwater runoff includes the runoff from all MFC building roofs and inside the fence ground-level surfaces. There is also a small volume of monitored industrial wastewater from facilities. The highest volume of water flow occurs subsequent to rain storms and during winter snow/ice meltoff. Currently flooding occurs in the lower levels of the nuclear facilities HFEF, FCF, AL, FMF/PIDAS, and various U\&IS administrative buildings due to the poor drainage. Flooding of manholes and equipment vaults also occurs and potentially causes degradation of electrical and telecommunication wiring. There is also damage occurring to facility foundation walls. At the present time, MFC does not have a drainage system specification that would be referenced when developing plans for future expansion.

\section{Benefit}

Properly engineered, graded, and maintained drainage systems greatly reduce the pooling of water from storm surge and meltoff. This reduces the likelihood of personnel injury due to slips/trips/fall hazards due to uneven surfaces or when the pools freeze. A comprehensive drainage-system specification would include the covering of open ditches, correct gradient requirements, and allow for project/facility expansion within system civil engineering specifications. Proper drainage would eliminate the flooding of facility basements and reduce damage to facility foundation walls.

\section{Facility Risk}

The risk of not improving the drainage system and allow continued flooding:

- Introduces a safety concern - currently there are electrical vaults and manholes that frequently flood and introduce the potential for water to cascade via conduit runs to switchgear in facilities

- Damage/degrade facility structure and equipment

- Leave standing pools of water that freeze in the winter

- Water infiltration into buildings can be a radiological issue

- Erosion of existing ditches and culverts further exacerbates the drainage problem

- Manual labor spent pumping down electrical manholes and vaults

- Potential to periodically shutdown facility operations

- Integration of new projects without a sitewide drainage plan

ROM Cost Estimate: \$2.1M. Laboratory Investment. 


\section{MFC Inside-the-Fence Pavement Upgrade}

\section{Description}

MFC interior roads include 8 miles of paved and 2.6 miles of gravel road. A significant portion of pavement is driven or parked on by heavy equipment. Additionally, the paved areas support the majority of foot traffic. These interior roads and common areas need to be maintained to ensure standby-response vehicles can access all parts of the facility, materials can be delivered, and maintenance, security, operations, etc. can perform their daily duties to support the various programs.

The MFC U\&IS budget can support minor asphalt work, such as pothole repair and minor crack sealing, but it is not able to fund larger-scale maintenance on the common areas, parking areas, and roads. This has resulted in the cracks in a large percentage of road surfaces going unsealed through multiple winter snow, freeze, and thaw cycles. Large portions of the interior roads have deteriorated, lost service life, and require investment in surface restoration/reconstruction. The deterioration is largely due to water infiltration that accelerates crack propagation and consequent road-base failure. Most of the asphalt surfaces at MFC are not in optimum condition: however, 9 areas have been identified as needing immediate attention. That combined area totals $\sim 139,000 \mathrm{ft}^{2}$.

\section{Benefit}

Properly maintained roadways and walking paths minimize the potential for personnel injury due to slips/trips/falls from uneven/potholed surfaces and slick surfaces (ice buildup).

\section{Facility Risk}

Improperly maintained roads impact the drivability and, to some extent, the safety of the road. Increased cracking and reduced load-bearing capacity of the road leads to further degradation of the road base and increased life-cycle cost. Unaddressed road degradation affects day-to-day operations and emergency response activities.

ROM Cost Estimate: \$2.1M. Laboratory Investment. 


\section{MFC HVAC Replacement Campaign}

\section{Description}

The majority of administrative buildings at MFC are more than 30 years old. Infrastructure like HVAC is largely original equipment and failures are common, replacement parts are unavailable, and the units are inefficient. In the case of the L\&O building, direction of air flow is important not only scientific, executive, and administrative staff, but also to the connected Analytical Laboratory. The temperature control requirements for personnel comfort are extremely challenging when relying on HVAC equipment that is in various stages of disrepair.

\section{Benefit}

Properly ventilated, heated, and cooled working environments are critical when expecting optimal performance of personnel in their workspaces. Updated HVAC equipment will reduce the amount of emergent maintenance required during the hottest part of the year.

\section{Facility Risk}

The daily temperature variance, high summer and very low winter-temperature extremes can result in very uncomfortable working conditions. The conditions can be less than ideal for operating equipment. Unreliable and inefficient HVAC equipment poses large manning requirements for personnel with specific maintenance capabilities. Personnel output is reduced both in volume and quality when working environments are not satisfactory.

ROM Cost Estimate: $\$ 400 \mathrm{~K}$ per multi-year campaign. 


\section{Install Pyro-Chemical Glovebox in FASB}

\section{Description}

This is a lab investment to replace an existing aging glovebox in FASB. This glovebox support multiple R\&D program. The current glovebox has poor atmospheric controls.

\section{Benefit}

$\mathrm{R} \& \mathrm{D}$ work that utilize certain salts require tight control on oxygen and moisture levels that are not achievable with the current glovebox. More R\&D program work is requiring use of salts that cannot be support by the current glovebox. The replacement glovebox will be able to support a wider variety of research.

\section{Facility Risk}

Poor atmospheric controls within the glovebox limits the type of experiments the furnaces can support and can add uncertainty to the results achieved.

ROM Cost Estimate: $\$ 800 \mathrm{~K}$. Lab investment. 


\section{2. - 35. DOE-EM Funded Removal of Obsolete Equipment, Components, and Structures}

\section{Description}

Funding has been provided to the INL through DOE-EM to removes obsolete equipment, components, and structures that are no longer needed to support the RD\&D mission. The INL is working in collaboration with the DO-EM cleanup contractor to identify candidate areas where this equipment can be removed freeing up space to support the NE mission.

Candidate areas currently identified include:

- Removal of obsolete deactivated equipment from the ZPPR control room

- Removal of gloveboxes and hoods no longer needs or used within ZPPR, FMF, and FASB

- Deactivations and dismantlement of liquid waste treatment equipment within RLWTF and SCMS

- Dismantlement and removal of the Argonne Fast Source Reactor Structure in EML

\section{Benefit}

The focus of this effort is to capitalize on existing NE RD\&D footprint that can be made available to support current and future missions by creating research space within existing facilities. This helps alleviate current needs for additional research footprint to house emerging RD\&D capabilities and optimize the use of existing space within the nuclear and radiological facilities.

\section{Facility Risk}

The primary risk for no action is these pieces of equipment will not be remove and will remain a legacy liability that the INL will need to address at some point in the future. This also creates additional need for new facility footprint to support the growing NE Test Bed.

ROM Cost Estimate: Costs are being planned and negotiated with the DOE-EM cleanup contractor. 


\section{Replace Elementary Neutralization Units (ENU) Drain Piping}

\section{Description}

The ENU piping of the Materials and Fuels Complex Analytical Laboratory (MFC-752AL) shows signs of leakage and corrosion. Therefore, the ENU collection system is currently out-of-service (OOS) requiring sample solutions be collected in a tote prior to disposition. The tote is located in the A-wing of the AL, a significant distance from the general chemistry lab rooms where sample preparation and analysis is conducted. The primary cause of this damage has been attributed to an incompatibility of existing piping material (stainless steel) and the concentration of waste chemicals and waste constituents being generated by the Analytical Laboratory (AL) and discharged through the ENU drain piping network. As a result, all piping upstream and downstream of the ENU is to be replaced with a more suitable piping material.

\section{Benefit}

Placing the ENU drain piping system back into service will result in a significant efficiency gain for lab personnel. Working lab room sink drains will allow direct disposal of sample solutions following analyses into the lab room sink with drain piping tied to the ENUs. Additionally, having working sinks will allow the AL to install water purification systems local to each room rather than utilizing one purification system in room B-141, improving lab personnel efficiency for sample preparation.

\section{Facility Risk}

Not having a working ENU collection system severely impacts lab personnel efficiency for both sample preparation and sample solution disposal post analyses.

ROM Cost Estimate: $\$ 3 M$. 


\section{HFEF Exterior Roof/Stack Access Stairs}

\section{Description}

Current HFEF emergency stack ladder has been condemned as unsafe and removed form service. Installation of a stair tower to replace the condemned ladder will provide the same function as the ladder it replaces by providing a safe access to the stack and access for security for equipment installed on roof.

The work scope of this project is to design a stair tower that meets the OSHA requirements and to supply HFEF with the seismic reaction to verify that the building seismic rating is not compromised. The project will build the stair tower either off or on-site, the preferred is off-site. The stair tower will be installed, this will require excavation and structural steel work. The tower is to be self-supporting but will require lateral support from the building. There is no electrical work associated with the project.

\section{Benefit}

The addition of exterior stairs to provide roof and stack access at HFEF will provide a safer way to access the roof as well as providing a more efficient way to move equipment to the roof.

\section{Facility Risk}

The existing ladder has been condemned unsafe and does not meet OSHA requirements. This impacts access to the stack and security equipment located on the roof.

ROM Cost Estimate: $\$ 500 \mathrm{~K}$. 


\section{HFEF Argon Compressor Removal}

\section{Description}

The HFEF argon compressors are being replaced by a bulk argon system. Once the bulk system is operating the compressors must be removed to provide additional space for other uses. The main scope of work for this project is the removal of the argon compressors and associated equipment in the HFEF basement. Specifically, this project will:

1. Review drawings and identify system components for removal

2. Remove compressor piping

3. Remove the two argon compressors

4. Remove the two compressor receiver tanks

5. Remove the compressor electrical and controls components

6. Remove the associated concrete equipment pedestals

7. Disposal of removed components and waste generated from equipment removal.

\section{Benefit}

Removal of the Argon compressors in HFEF will free up valuable real estate for other uses such as a transfer station to support NRAD and IMCL operations.

\section{Facility Risk}

The risk to the facility if the compressors are not removed is that equipment is abandoned in and occupies space that can be used for other functions including the support of program work.

ROM Cost Estimate: $\$ 500 \mathrm{~K}$. 


\section{HFEF Argon Regeneration Valves}

\section{Description}

The regeneration system in HFEF provides heated dry air and argon for regenerating the purification system dryers. The regeneration valves are old and need replacement. The summary of work for this project is the procurement and replacement of the HFEF argon cell regeneration valves. This includes design of components to ensure proper interface of the new valves with existing piping.

\section{Benefit}

Replacement of the regeneration valves will increase the reliability of the regeneration system.

\section{Facility Risk}

The risk to the facility if the regeneration valves are not replaced is the increased chance of the regeneration system failure which in turn would impact the facility capabilities to support programmatic work.

ROM Cost Estimate: $\$ 500 \mathrm{~K}$. 


\section{Convert RCL from Steam Heat to Electrical Heat}

\section{Description}

The objective of this work is to replace the existing inline duct steam heater with an electrical coil for the Radio Analytical Chemistry Laboratory (RCL) at the Materials and Fuels Complex (MFC) located at Idaho National Laboratory (INL). Included in this work is a using subcontracting to replace the steam unit with an electrical heat coil, including the following demolition of steam piping and capping of lines, temporary removal of electrical and piping to facilitate the removal of the steam unit, removal of a large section of duct to allow removal of the steam unit, construction of new duct section to allow proper fit up of the new electrical unit, and tie in to the existing system, installation of a new $1200 \mathrm{amp}$ electrical panel, and running conduit and wire to feed the new panel from the substation in room.

\section{Benefit}

The main benefit is to have better control of the heating within the RCL. Some of the instrumentation within the RCL requires the temperature fluctuation to be small. This would enable the ability to better control the heat to within the required temperatures. It would also correct an issue that would have to be fixed with a maintenance request; that being a hole in the steam coils. The costs benefit of upgrading at this time instead of replacement is increased as a result.

\section{Facility Risk}

Currently, we have a hole in the steam coil that requires maintenance to be performed. The system is being used, but there is an increasing risk of failure the longer we go without correction. Failure of the system would result in no heat to the building. There have already been several repairs made to the system and the costs of the repairs continues to increase and each repair increases the risk further.

ROM Cost Estimate: $\$ 700 \mathrm{~K}$. 


\section{Design, Fabricate, and install New FCF Feedthrough to Support $\mathrm{CO}_{2}$ Cold Jet Decontamination System}

\section{Description}

The SDI Select 60 Cold Jet CO2 Blast Unit (Cold-jet) has been tested for contamination removal of materials (e.g. manipulators \& EMMs) in the FCF Decon Spray Chamber (DSC). The use of the Cold-jet was demonstrated to significantly reduce surface contamination in some conditions and thereby further achieve ALARA objectives. To support the permanent installation and effective use of the new cold-jet decon system at FCF, a new feedthrough needs to be designed, fabricated, and installed in the DSC. We will modify an existing feedthrough to fit the needs of the cold-jet system.

\section{Benefit}

The use of the Cold-jet was demonstrated to significantly reduce surface contamination in some conditions and thereby further achieve ALARA objectives. The feedthrough will facilitate more efficient and effective use the cold-jet system.

\section{Facility Risk}

Without this new feedthrough the use of the Cold-jet system in the temporary non-routine procedure process requires multiple Suited Entry Repair Area and DSC entries which is not in alignment with ALARA objectives and causes measureable delays in the decontamination process.

ROM Cost Estimate: $\$ 350 \mathrm{~K}$. 


\section{HFEF MetBox Refurbishment}

\section{Description}

The met cell is a small, shielded, inert gas-filled hot cell (located in Room 123). The cell houses a Leitz Model MM-5RT gas-sealed metallograph, a LECO AMH55 Micro-Hardness Tester used for microhardness testing, and a Leica DMi8 Advanced Microscope used for microscopic examination of prepared samples. The cell maintains the inert atmosphere required for loading and examining samples and shields personnel from radiation from the samples. The atmosphere control system maintains an inert gas atmosphere $(<$ ppm O2 and $\mathrm{H} 2 \mathrm{O})$ in the loading cell. It is maintained at negative pressure with respect to Room 123, and is regulated by its own controls located on the north wall of Room 123. The met-cell atmosphere is automatically controlled by the feed and bleed, analytical instrumentation, cell-exhaust, purification, and nitrogen/Argon systems.

\section{Benefit}

Restoration of full capabilities optimized RD\&D support efficiency and reduces rework on samples.

\section{Facility Risk}

The only atmospheric control that is currently functional is pressure and thus there is no information for the purity of the atmosphere in the Met Box. Not controlling the atmosphere allows oxygen and moisture into the atmosphere which causes oxidation of the Met mounts and degradation of susceptible system components.

ROM Cost Estimate: $\$ 500 \mathrm{~K}$. 


\section{HFEF Containment Box Lid Seal and Hoist}

\section{Description}

The HFEF Containment Box, along with its associated support equipment, is located in the HFEF main hot-cell. The containment box is an enclosure that isolates the station from the main cell atmosphere. The purpose of the containment box is to isolate an area for use in preparation of metallographic specimens for optical microscopy and hardness testing. This enclosure is necessary because metallographic operations require the use of liquids that could be harmful to the system used to purify the main cell argon. Additionally head-end operations prior to sample preparation (grinding and polishing) require sawing operations that produce fines that also need to be isolated from the main cell environment for contamination purposes. Issues related to the containment box that require attention include a lid and doors that no longer seal properly, aging controls and cooling systems that require upgrade, and aging hoist capabilities within the enclosure.

\section{Benefit}

Correcting the previously mentioned issues will improve isolation of the containment box interior from the main argon cell as well as improve reliability of the containment box functions.

\section{Facility Risk}

The risk to the facility is delay of program work should the door and lid seals completely fail or should the box controls or cooling system fail. It is estimated that containment box down time would exceed 9-12 months should complete failure occur.

ROM Cost Estimate: $\$ 500 \mathrm{~K}$. 


\section{FCF MTG Revision and User Interface Update}

\section{Description}

The FCF Material Tracking System (MTG) is aged and portions of the system do not lend themselves to the NQA-1 software quality rules where testing is concerned. FCF Process operators experience errors because the user interface does not clearly display process flow of the MTG which changed over the last 10 years and software modification of the HTML process screens is necessary. Original development team with Argonne was 15 developers. In the last 10 years this has been reduced to 2 part-time developers who have other responsibilities to the Pyro Processing project. A team of software engineers is needed to not only maintain the system, but to help update the code to meet the NQA-1 standards for regression testing and quality. The scope of this effort will be to replace the current process flow screens with new updated process flow screens to meet the current mission.

\section{Benefit}

The scope of this effort will replace the out dated process flow screens with new updated process flow screens and update the code to meet the NQA-1 standards for regression testing and quality and significantly improve process flow software changes to the system to make the facility process simpler and easier to follow with minimum delays to meet the current mission.

\section{Facility Risk}

Without this revision and update EBRII Fuel Processing and HALEU Production activities relying on MTG will be challenged to demonstrated compliance with NQA-1 standards and effective and efficient process activities.

ROM Cost Estimate: $\$ 795 \mathrm{~K}$. 


\section{Ultra-Pure Water Stations}

\section{Description}

Ultra-pure water stations deliver on-demand water that has been purified and de-ionized to a conventional standard and that ensures native elemental species in supplied water do not interfere with the quantification of elemental and isotopic analytes in solutions under investigation. To maximize the efficiency of laboratory operations and take full advantage of the ultra-pure water characteristics, these water stations should be installed wherever sample preparation occurs in the laboratory, typically those rooms with benchtop areas and fume hoods for preparative work.

\section{Benefit}

The majority of the Analytical Laboratory's (AL) elemental and isotopic analyses require the use of ultrapure water in all steps of the sample and standards preparation processes to prevent the introduction of contamination that will alter the results of the analyses. The sensitivities of the mass spectrometers, for example, are so high that low concentrations of samples are used to achieve increasingly lower detection limits of analytes. Native elements present in the water used to prepare the dilution acids could skew measurement or result in false-positive detection. Ultra-pure water is therefore necessary to ensure accuracy in challenging measurements.

Because sample preparation, including dilutions, takes place in each benchtop laboratory space in the AL, it is necessary to have local ultra-pure water stations in each of the pertinent rooms. The need to access ultra-pure water rapidly arises with sensitive analytes and acids. In addition, the need to reduce the handling of the water by, for instance, transporting it from one room to another, is critical because increased handling results in greater probabilities of introducing contaminants. Ultra-pure water stations at each benchtop increases the AL's sample throughput and improves quality control and assurance.

\section{Facility Risk}

The absence of ultra-pure water stations at each benchtop (or one per laboratory room) limits the accuracy and precision of the AL's results and jeopardizes the AL's ability to meet ultra-low detection limits in its characterization of low levels of impurities in experimental fresh fuels, and it also reduces the precision in the characterization of used fuels during post-irradiation characterization, both of which functions are critical mission areas for the AL.

ROM Cost Estimate: $\$ 240$ K. 


\section{Cask Integration, Management, and Capability Sustainment}

\section{Description and Benefit}

A number of casks are utilized to support movement of nuclear materials between facilities and to support disposition of wastes generated as part of R\&D activities at MFC. Operability of these casks is critical to the safe, compliant operation of MFC's nuclear facilities. Focused integration and management of the casks is integral to efficient and effective nuclear operations. Inoperability of the casks can result in substantial programmatic impacts across multiple facilities and programs, representing a single point failure mechanism. This investment includes establishing a coordinated cask integration and management capability, cask sustainability actions, and development of a new cask/container for transport of legacy wastes from MFC to the new RH-LLW Disposal Facility.

Integration and management of casks $(\$ 300 \mathrm{~K})$ is critical to efficient facility operations. Coordination of use, preventative maintenance, and sustainment/refurbishment activities will help ensure that the casks are available to support program needs, when needed.

Substantial issues were encountered in FY-18 associated with the HFEF-5 cask that negatively impacted RH-LLW Disposal Facility operational readiness activities and constrained waste/material movements critical to supporting R\&D outcomes at MFC. These issues resulted in increased corrective maintenance costs significantly above historical averages to ensure base cask operability. Associated analyses are expected to identify modifications to the existing HFEF-5 that are required to support safe operations within a range of operating conditions that must be supported to not impact R\&D outcomes. Similar deficiencies may be present with other existing casks at MFC. This plant health investment $(\$ 500 \mathrm{~K}-$ $\$ 700 \mathrm{~K}$ ) will support a methodical evaluation of the casks and implementation of necessary corrective actions, including modern analyses and modifications, if necessary to support safe operations.

The RH-LLW Disposal Facility is in the process of completing operational readiness. The facility includes final disposal locations for 250+ legacy waste containers stored at the Radioactive Scrap and Waste Facility at MFC. Transfer of this legacy waste for final disposal requires a cask/container system that supports the configuration of the waste canisters. This investment includes final evaluation, design, and fabrication of a cask/container to support transfer of the waste stream to the RH-LLW Disposal Facility $(\$ 1.2 \mathrm{M}-\$ 2.0 \mathrm{M})$.

Existing casks represent a single-point failure. Investment to procure additional casks (i.e., HFEF-5 cask and GE-2000 cask) is warranted to ensure that R\&D outcomes are not impacted due to operability issues and conflicting demands with existing casks. (\$3.5M-\$4.5M)

\section{Facility Risks}

Failure to fund and implement a focused cask management and sustainment capability increases the risk that inoperability of a given cask will negatively impact MFC R\&D outcomes and the potential for noncompliances due to an inability to properly maintain the physical and analytical bases for the casks.

ROM Cost Estimate: $\$ 5.5 \mathrm{M}-\$ 11 \mathrm{M}$. 


\section{Appendix B}

\section{Detailed Descriptions of Instrument Capability Activities}


MFC FIVE-YEAR INVESTMENT STRATEGY

Appendix B

Detailed Descriptions of Instrument Capability Activities 


\section{Appendix B}

\section{Detailed Descriptions of Instrument Capability Activities}

\section{Completion of the Thermal Properties Cell and Glovebox in IMCL}

\section{Description}

This effort includes completion of the installation of the thermal properties cell and glovebox, an effort that began in FY-18. Completion of this will provide the support infrastructure required to house thermal properties instruments discussed further.

This project installs and qualifies thermal property measurement instruments in the IMCL thermal property shielded cell.

\section{Benefit}

Thermal properties define the performance limits of nuclear fuel under irradiation. In most fuels, information on thermal conductivity as a function of burnup and temperature do not exist. This results in conservative assumptions about thermal conductivity that increase the required safety margin and decreases the reactor operating envelope. These instruments include LFTD (Laser Flash Thermal Diffusivity), DSC (Differential Scanning Calorimetry), a thermal expansion measurement system, and a thermal conductivity microscopy. Ancillary equipment for sample coating and microscopy will also be provided.

The current state-of-the art method for measurement of thermal conductivity involves three measurements; a thermal diffusivity measurement using LFTD, a heat capacity measurement using DSC, and a measurement of density as a function of temperature by one of several methods. This system provides excellent capabilities for measurements of fuels and materials that can be fashioned into regular disc shapes for the LFTD measurement. This suite of instruments provides data on thermal conductivity to temperatures of approximately $1500^{\circ} \mathrm{C}$.

The thermal conductivity of irradiated fuel can be very difficult to measure using the standard laser-flash thermal- diffusivity method, because it requires a well-defined sample with specific dimensions.

Irradiated fuel is often either fragmented, has the wrong diameter, or contains a center void that prevents the straightforward use of the LFTD method. In order to address these issues, INL has developed the TCM (Thermal Conductivity Microscope). Unlike the standard LFTD method, TCM allows thermal conductivity measurements to be made on fragments of irradiated fuel below $500^{\circ} \mathrm{C}$. The existing $\mathrm{TCM}$ will be installed in the IMCL Thermal Properties Cell.

The TCM method, together with LFTD must be used together to cross calibrate measurements and obtain a complete picture of thermal conductivity as a function of temperature for irradiated fuel.

Status: The TPC installation completed in November 2018. The LFTD, DSC, and thermal expansion system will be procured, installed, and qualified. The TCM has been developed and tested on the bench scale with radiological materials; remotization and qualification are required. Several other small pieces of equipment are required for sample handling, coating, inspection, and measurement.

ROM Cost Estimate: $\$ 3.5 \mathrm{M}(\$ 1.9 \mathrm{M}$ to complete the cell and glovebox, $\$ 1.6 \mathrm{M}$ to install the instruments. 


\section{Expanded Fuel Fabrication Capability}

\section{Description}

This strategy addresses multiple facility and process equipment upgrades to MFC fuel fabrication capabilities in several facilities in an attempt to meet continually increasing demand. The capability expansion under this strategy is intended to address our short term ( 5 year) RD\&D Test Bed needs within existing MFC facilities and planning for possible future expansion.

1) There is a need to improve our basic science capability by providing high purity actinide materials and single crystal samples for characterization and evaluation. 2) Current applied science fuel fabrication research areas include plate fuel development, fast reactor fuels, transmutations fuels, advanced reactor fuels, and performance enhanced LWR and PWR fuels (accident tolerant fuels), all of which need to continuously improve processing techniques, including the use of advanced manufacturing techniques. 3) INL fields numerous requests to fabricate multi-kilogram quantities (engineering scale quantities) of experimental fuels including accident tolerant fuels for existing LWRs, as well as, develop fabrication processes for and build fuel in quantities sufficient for licensing of sodium-cooled fast reactors for industry, demonstrate fabrication of recycled fuel (Joint Fuel Cycle Study with KAERI), and conduct a special one-of-a-kind projects for advanced and unique reactor concepts. These requests have highlighted the need for expanded fuel fabrication capabilities.

\section{Benefit}

Expanding our basic science capabilities will allow the study of the fundamental properties of actinide materials that could provide valuable data for fuel performance modeling. Producing single crystals of uranium alloys and uranium doped materials will open up numerous fundamental property evaluations (including semiconductor characteristics) as well as provide unique irradiation opportunities to see how single crystals perform under irradiation and respond to irradiation damage. These capabilities will also help drive fuel development from an empirical art to a science.

In conjunction with the Lab initiative in advanced design and manufacturing, maintaining our leadership in applied fuel fabrication science requires keeping up with ever improving fabrication and manufacturing techniques. Many of these new fabrication techniques will open up fuel and cladding design options that where not possible with traditional fabrication techniques. Examples of advanced manufacturing techniques that are funded and require laboratory space to deploy are Spark Plasma Sintering (SPS), additive manufacturing, continuous metal fuel casting, metal fuel co-extrusion, and laser welding of cladding. Numerous other options are available that should be considered for applied science evaluation for use with nuclear fuel.

Many of the requests received by INL require large-scale fabrication campaigns under an NQA-1 program (Nuclear Quality Assurance) to increase the Technological Readiness Level through demonstration of fabrication and irradiation performance. These larger-sale campaigns, which cannot be conducted elsewhere, push the licensing constraints of our existing facilities and in some cases may make these activities impossible to execute in current facilities. Evaluating all of our current facilities to house engineering scale demonstrations such as these will be an on-going effort depending on the fuel fabrication process equipment needs and the quantities of finished fuel that is required.

Initially, additional capacity for RD\&D can be made available by removing several obsolete glove boxes from existing facilities and repurposing several additional buildings. The objectives for individual facilities are provided below.

- Fuels and Applied Science Building (FASB) - Maintain as a general-purpose uranium-based fuel fabrication laboratory. Remove the obsolete "development" glove box line to make room for new Pyrochemistry glove box. Maintain characterization lab space adequate to rapidly and efficiently gauge process development. 
- Experimental Fuels Facility (EFF) - Maintain EFF as uranium-based fuel fabrication laboratory. Improve facility process flow as needed to support RD\&D needs.

- $\quad$ FMF - Primary transuranic-based (TRU) fuel development facility. Remove obsolete waste characterization glove box to allow for expansion with new glove boxes for casting and sample preparation. Evaluate the possibility for fabrication of demonstration-scale expansion to meet demand. Continue to develop and expand MOX applied research fabrication capability.

- Zero Power Physics Reactor building (ZPPR) - Expand work room capability to allow for higher enrichment and large quantity uranium-based fuel fabrication. Evaluate cell and alcoves for expansion of uranium-based processes.

- $\mathbf{A F F}$ - Repurpose this storage facility into a radiological facility in the same manner as EFF to allow deployment of advanced manufacturing techniques and relieve facility nuclear material quantity limits on other facilities.

- Fuel Safety Research Lab - Expand capability and infrastructure to support TREAT experiment assembly and disassembly.

- HFEF - Develop remote fuel fabrication, as needed for the JFCS and for TREAT experiment refabrications.

- $\quad$ FCF - Expand capability to gravity cast FCF uranium product into molds. Evaluate further fission product removal from FCF product to foster contact handling. Support HALEU feedstock preparation.

- $\quad$ RLWTF, INTEC-651, INTEC-1634 - Evaluate for repurposing into Hazard Category II fuel fabrication facilities.

- Engineering Scale Reactor Fuels Fabrication Laboratory - Continue to evaluate concepts for a new modern fuel fabrication facility.

ROM Cost Estimate: On going evaluation, initial \$3.5M investment in FY-18. 


\section{Mass Spectrometers for AL (Quad/ToF-MS/LA-LIBS)}

\section{Description}

Currently, AL owns one quadrupole ICP-MS (Elan DRC) purchased in 2005. This is essential to the support of programmatic, compliance, and waste characterization work, but its age and workload increase the probability of failure. There is an Increasing backlog of samples as more customers come to AL for analyses.

\section{Benefit}

Loss of the aging Elan would delay indefinitely the majority of programmatic support. Dated hardware and software of the current instrument result in suboptimal analyses. Replacement parts are becoming more difficult to find

Limited current AL sample throughput can be significantly enhanced with a Time-of-Flight mass spectrometer (ToF-MS). Current AL mass spectrometers must calibrate in different mass ranges, increasing analysis times and producing more waste.

The AL's sample throughput is impacting the ability to meet demands as programs and programmatic scope increases. The ToF-MS also increases the ability to keep up with advancements in measurement science as technological advancements in other facilities grow. This allows AL to expand to multi-faceted capabilities as the ToF-MS can be easily coupled with other techniques.

Current AL methods for isotopic analysis lack the capability of surface profiling: only bulk material composition is measured. Surface profiling can give information on homogeneity or how the composition of a substance varies by depth. Laser Ablation-Laser Induced Breakdown Spectrometry (LA-LIBS) allows AL to take advantage of national and international collaboration opportunities, such as expanded partnerships with the Korean Atomic Energy Research Institute (KAERI), the Lawrence Berkeley National Laboratory (LBNL), and the Department of Homeland Security.

A new Quadropole, ToF-MS, and LIBS along with replacement counting equipment was procured in FY-18 with installation planned for FY-19.

ROM Cost Estimate: $\$ 3.8 \mathrm{M}$. 


\section{HFEF GASR Refurbishment}

\section{Description}

The GASR (Gas Assay Sample and Recharge) system provides the ability to laser puncture irradiated fuel rods, measure fission gas pressure and fuel rod internal void volume, and if needed, refill/repressurize the rod with gas and weld the puncture hole closed. The GASR system also collects fission gas samples for composition and isotopic analyses.

\section{Benefit}

GASR data is critical for understanding the performance of all rod or pin-type fuels and contributes heavily to the licensing bases for these fuels. The GASR system has been maintained over its 30-year life, but never significantly upgraded. Many system components have become unreliable and component failure rates have increased dramatically over the last 2 years. The GASR system was inoperable for 4 months in FY-14, 1 month in 2015, and 1.5 months in FY-16. GASR failures have impacted PIE schedules for several programs. Replacement components are obsolete, and recent repairs were completed using parts purchased from eBay. Repairs have not restored 100\% system capability. The GASR is scheduled for more than 1500 hours of operation in FY-17. Replacement of the system is necessary to ensure system reliability for future PIE campaigns.

GASR failure rates are increasing. Upgrade and replacement of mechanical and electrical components, the GASR laser, electrical feedthroughs in the hot cell confinement boundary, and electrical control cabinets are necessary to ensure the reliability of these systems.

ROM Cost Estimate: $\$ 800 \mathrm{~K}$. 


\section{TREAT Experiment Handling Support at HFEF}

\section{Description}

HFEF is coordinating with TREAT to address restoring TREAT experiment handling capabilities in the HFEF Decon Cell. Current planning is centered on hot cell clean-up and experiment handling capabilities in the $5 \mathrm{D}$ window.

\section{Benefit}

TREAT basic experiment support and waste clean out for FY-19 is shown in Table 6. In addition to the clean-up and basic test handling capabilities, installation of loop handling and check-out systems, and installation of refabrication capabilities are planned beginning in FY-20. These new systems provide the support needed for handling and testing water and sodium based loop experiments before delivery to TREAT for operation. These additional activities are shown in Table 7.

Planning commenced in FY-18.

ROM Cost Estimate: \$1M. 


\section{HFEF East Radiography Station Elevator Repair}

\section{Description}

Virtually all programmatic work that comes through HFEF starts with neutron radiography (nondestructive PIE). Critical decisions for destructive PIE are based on results from neutron radiography.

The ERS elevator mechanical and electrical control systems are original equipment, circa 1980.

Components and spare parts are obsolete and no longer commercially available. Current controls do not allow for rotation of samples in the elevator. Tomography can only be supported with sample rotation "by hand," adding significant time and cost to research efforts.

\section{Benefit}

Several functions of the elevator are out of service and can only be fixed with a complete upgrade (full up and down positioning detection, determining cable reel slack). A lack of position detection causes some images to be misaligned and requires rework, adding significant time and cost to research efforts.

Utility feed-through has failed circuits that have been bypassed with a temporary jumper.

Failure of obsolete components would result in long lead times to regain operational status, jeopardizing HFEF's ability to meet mission outcomes (if the elevator is not working, then programmatic work cannot move on from nondestructive to destructive PIE).

An up-graded elevator and control system would allow neutron radiography to become more efficient, less expensive, and provide greater reliability and repeatability to programmatic campaigns. The addition of rotational sample control will allow for Neutron Tomography to become a more cost effective nondestructive PIE capability.

This was funded in FY-18 and in currently being executed.

ROM Cost Estimate: \$1M. 


\section{North Radiography Station Footprint Repurpose}

\section{Description}

This effort will repurpose footprint and restore support capabilities for the north beam line area in HFEF to support digital neutron imaging advancement, neutron diffraction, and new neutron science for irradiated fuels and materials in the North Radiography Station in HFEF. Existing backup generators and out-of-service equipment occupies space that is needed to support new programmatic research on advanced neutron imaging techniques and neutron science for irradiated fuels and materials. New research equipment cannot be installed until new backup generators are installed elsewhere and obsolete equipment is removed. Beam line modifications are required for development of new techniques to be effective.

\section{Benefit}

NRAD north beam line and elevator controls are original 1980 equipment with degraded operation and no spare part availability. When the elevator controls do not function, irradiated experiments requiring remote handling cannot be examined in the NRS.

This enables facility mission expansion by creating space for additional beam lines and instrumentation with ties to IMCL/SPL/TREAT research based on beam layout and capability. Elevator and beam controls support TREAT loop experiment and industry partner experiment examination.

This also enhances spatial examination of irradiated fuels by nondestructive means, and improved understanding of behaviors in realistic conditions such as neutron tomography, neutron powder diffraction, kinetic testing with combined techniques, time-of-flight studies, X-ray scattering, X-ray $\mu \mathrm{CT}$.

Removal of legacy equipment eliminates existing liability (hazardous materials) and reduces future liability.

This was funded in FY-18 and in currently being executed.

ROM Cost Estimate: $\$ 3.2 \mathrm{M}$. 


\section{Purchase/Installation of New MC-ICP-MS in the Analytical Laboratory}

\section{Description}

The Analytical Laboratory is planning to purchase and install the next generation Plasma 3 multi-collector inductively coupled plasma mass spectrometer (MC-ICP-MS) to ultimately replace the existing instrument placed into service in 2010. The existing MC-ICP-MS has a life expectancy of approximately 10 years. The new Plasma 3 instrument has a lead time for manufacture of 10-12 months. Upon delivery, installation, acceptance testing and turnover will take approximately 3 months to complete. The plasma 3 is needed to meet increasing programmatic needs and maintain a leading role in nuclear research capability.

\section{Benefit}

Purchase and installation of a new multi-collector will allow us to have the latest technology on the instrument and ensure there is no interruption in being able to process samples through the existing instrument. The hope is that we will be able to use both instruments for a short period of time and to have a backup instrument in case one goes down. As the current multi-collector reaches the end of its life, we can expect to see an increase in downtime for repairs to the instrument. Due to the lead time for purchase and install of a new multi-collector, the further we delay the purchase, the more risk we are taking on. The negative impact to programs using the instrument will continue to increase.

ROM Cost Estimate: $\$ 2.5 \mathrm{M}$. 
MFC FIVE-YEAR INVESTMENT STRATEGY

Appendix B

Detailed Descriptions of Instrument Capability Activities

\section{Re-establish TREAT Na Loop Capability}

Please see Appendix C for TREAT related information 


\section{Establish Nondestructive Assay (NDA) Capabilities in FCF}

\section{Description}

Radiological characterization of waste and other materials is an essential step for removing items from the FCF hot cell. Technicians use process knowledge and characterization data to select the type of waste packaging best suited to remove waste from the facility. Current and past practice of acquiring accurate radiological characterization data has required a transfer of the items from the hot cell to an area with a lower radiological background dose rate. Frequently, multiple transfers are required introducing ALARA concerns to the radiological workers and inefficiencies to the overall process. Installation of Non Destructive Evaluation instrumentation which utilizes existing Non-Destructive Assay ports located between the hot cell and the sub-cell basement area provide an opportunity to reduce the ALARA risks and minimize the impact on the treatment process.

\section{Benefit}

Improving initial radiological characterization methods by installing an in-cell characterization system (NDA) would improve initial characterization efforts and confidence in package selection while reducing ALARA concerns, as well as rework (cost and schedule impacts) associated with repackaging the waste. Use of the existing NDA port(s) will require awareness of the potential for inadvertent spread of contamination between the hot cell and sub-cell basement area. The current manual approach with material transfers impacts operational efficiency and increases the opportunity for error.

ROM Cost Estimate: $\$ 625 \mathrm{~K}$. 


\section{TOF SIMS (Time of Flight Secondary Ion Mass Spectrometer) for P- FIB (Plasma Focused Ion Beam) in the IMCL}

\section{Description}

The TOF SIMS (time of flight secondary ion mass spectrometer) will be implemented as a detector on a Plasma Focused Ion Beam (P-FIB) instrument in IMCL. The TOF SIMS provides a means of characterizing both the near surface chemistry and the isotopic composition of a material as a function of depth. The P-FIB has a multi ion source that provides a primary focused ion source that projects onto the surface of a material samples, causing secondary ions to be emitted from the sample surface. The atomic mass of the secondary ions is analyzed by the TOF SIMS. When combined with information from other P-FIB detectors that provide information on microstructure, grain orientation, mechanical properties, chemistry, and isotopic (burnup or transmutation), the TOF SIMS detector provides a complete picture of the response of a material system to irradiation. The TOF SIMS is a multi-programmatic instrument for which work will be prioritized based on program mission priorities and milestones and impact of applied and basic science.

\section{Benefit}

The instrument will allow for state of the art characterization of nuclear fuels and materials; very few of these instruments exist in the world in this configuration, and to our knowledge, none for use on nuclear fuels. Incorporating the TOF SIMS as a detector into a FIB instrument allows operational parameters (burnup, exposure) to be directly measured and related to behavior on the microstrucutural scale. The TOF-SIMS enables faster, more efficient, multimodal characterization of samples. Secondary benefits include reduced personnel exposure and reduced transfer of samples. Not acquiring a TOF-SIMS impedes continued development of advanced characterization methods for nuclear fuels and materials. These same methods are used universally in other industries (semiconductor, transportation, aerospace) to continually advance the state of technology.

ROM Cost Estimate: $\$ 600 \mathrm{~K}$. 


\section{Atom Probe Tomography Instrument in IMCL}

\section{Description}

Because irradiation damage occurs beginning on the atomic scale, atom probe tomography is ideal for the study of irradiation damage in materials. Atom Probe Tomography (APT) is the only material analysis technique offering extensive capabilities for both 3D imaging and chemical composition measurements at the atomic scale (around $0.1-0.3 \mathrm{~nm}$ resolution in depth and $0.3-0.5 \mathrm{~nm}$ laterally). We have recently pioneered the use of APT on irradiated fuels, which exhibit extremely complex behavior caused by fission; electronic energy transfer, compositional changes, and fission gas. The complexity associated with nuclear fuels, however, offers the opportunity for tailoring of fuel properties and performance, once understood. For example, the use of focused ion beam analysis has identified an association between solid fission products and fission gas that could be used beneficially to provide some control over gas-driven swelling.

\section{Benefit}

Current APT technology applied to the analysis of the complex multi element structure of irradiated fuel is limited by collection efficiency. The latest generation of atom probe exhibits a $20 \%$ increase in signal, resulting in greatly enhanced counting statistics and analysis. Analysis using a newer, advanced atom probe will greatly increase our ability to understand the underlying processes associated with microstructure development in nuclear fuel and therefore apply principles of materials design where it has never before been possible.

Use of instruments not collocated with the FIB instruments in IMCL (used to prepare APT samples) results in oxidation of reactive metals and unsatisfactory analysis. This request is for an instrument in IMCL.

This is being funded through Lab investment.

ROM Cost Estimate: \$4M vendor quote and estimated installation. 


\section{Process Development for Large-Scale Fuel Castings}

\section{Description}

This effort involves establishing an induction heated melting and casting system for large-scale casting. The location has yet to be determined but could exist at ZPPR, FMF, or repurposed space such as RLWTF.

Several fuel and reactor concepts are being evaluated that use larger fuel than traditional "slugs". These concepts range from micro-reactors to first of a kind scientific instruments. Some of these concepts may need 20-40 kg single castings in order to efficiently produce the fuel in a cost efficient manner. This size of casting is larger than much of the previous fuel casting capabilities, such as the EBR-II fuel fabrication process, but smaller than casting systems used for strictly depleted uranium castings. Capability to perform this size of castings have been lost in the DOE-NE complex and will be unique particularly to high assay low enriched uranium (HALEU) and therefore is an impediment to development of new reactor and fuel fabrication concepts, civilian and otherwise. Because this capability has not existed outside of classified space for several decades, once a furnace is designed to handle large masses there will need to be work done to evaluate how the system functions and how the castings behave during solidification. Parameters such as super heat, crucible materials, mold design and cooling, etc. will need to be evaluated for each alloy of interest. Some alloys of interest include uranium, U-Mo and U-Zr with and without other minor alloying additions. This furnace will also be capable of developing casting techniques and parameters for other novel fuel alloys.

\section{Benefit}

Expand our understanding of uranium alloy metal casting. Support efficient and cost effective deployment of advanced reactor concepts. Work will also provide a test bed for fabrication concepts and casting simulation benchmarking. Increasing our understanding of the kind of casting will reduce risk for future programs such as VTR and other metallic HALEU fuel concepts. Without engineering scale development capabilities advanced reactor deployment will be negatively impacted.

ROM Cost Estimate: \$1M. 


\section{Gas Mass Spectrometer Replacement in AL}

\section{Description}

The gas mass spectrometer (GMS) provides sensitive and precise measurement of permanent gas species. A static sample introduction system allows for grab samples of gases taken from other locations to be analyzed in the analytical laboratory (AL), even if the sample is extremely small or at low pressure. During analysis, gas species are ionized using an electron impact source and separated by their mass-tocharge ratio in a magnetic field. Detectors used in these instruments have been shown to be extremely linear over their detection ranges with fairly high sensitivities. This allows species to be reported as their mass-to-charge ratio or by the element's isotopic composition. The analysis and reporting of gaseous species mass-to-charge ratio is not possible by any other instrument currently employed in the AL. Further specificity in the instrument design can provide multi-collection (MC), increased sensitivity, high resolution, dynamic range, and/or increased sample type (organics, entrained gases, semi-permanent gases) capabilities in addition to those listed above.

\section{Benefit}

The major benefit of a new instrument is an increase in the reliability of our current analytical capabilities. A new MC-GMS will provide a capability that the laboratory does not currently have by allowing for high-precision isotopic ratio measurements of noble gases. Isotopic data of fission-produced gases can provide a range of information on the process and environment in which they were generated. The proximity of the AL to the Hot Fuel Examination Facility (HFEF) also provides unique analysis opportunities for gases generated during nuclear fuel irradiation and captured using the GASR instrument in HFEF's hot cells. In addition, the AL will be able to accept work that has previously been performed at recently decommissioned laboratories within INL, such as the Analytical Laboratory at RWMC. The Analytical Laboratory's GMS is aging and having significant problems due to equipment malfunctions. A replacement is needed to improve reliability and complement the expected work load of the lab. Much of this work is currently sent off-site to other laboratories with the capabilities, and an extended lapse in the capabilities at INL could result in a loss of customers and funding sources for future projects.

ROM Cost Estimate: $\$ 1.5 \mathrm{M}$. 


\section{Replace Leica Metallograph in HFEF}

\section{Description}

Replace the Leica microscope in the HFEF MetBox with a more robust unit, less susceptible to radiation levels found in the MetBox.

\section{Benefit}

The Leica microscope lost function of the 100X objective during the summer of 2018. Radiation levels in the MetBox are damaging to electronics and new instruments need to be re-engineered to be able to operate in that environment. A new state-of-the-art microscope would provide increased capacity for Met Box sample throughput and serve as a backup for the existing Leica. Alternatively, an entirely different system, Scanning Electron Microscope (SEM), would complement the Leica microscope and the LECO micro-hardness tester.

ROM Cost Estimate: $\$ 300 \mathrm{~K}$. 


\section{Digital Image Correlation for Mechanical Testing in FASB}

Facility: Fuels and Applied Science Building/Hot Fuel Examination Facility

\section{Description}

Digital Image Correlation increases the amount of information gathered about the fine details of deformation and failure during mechanical testing several-fold when compared to currently used strain gauges and extensometers. DIC techniques are increasingly used in science and engineering, especially in micro- and nano-scale mechanical testing applications due to its relative ease of implementation and use. Advances in computer technology and digital cameras have enabled this method and while white-light optics has been the predominant approach, DIC can be and has been extended to almost any imaging technology. This technology will be developed for remote use in FASB and implemented in HFEF.

\section{Benefit}

Investing in DIC (Digital Image Correlation) technology brings INL a technique commonly available at other laboratories that perform displacement and strain measurements on materials. DIC provides detailed full-field strain measurements that allow detailed characterization of failure modes in nuclear structural materials. Idaho National Laboratory (INL) currently lacks the capability to perform full-field displacement and strain measurements using DIC techniques. INL currently uses directly contacting displacement and strain gauge transducers, which do not provide full field displacement and strain measurements. Further, these contact transducers are extremely difficult to use on radiological materials, especially in the remote environment of the HFEF hot cell. DIC because it is non-contacting, simplifies use in a remove environment such as the HFEF hot cell.

ROM Cost Estimate: $\$ 200 \mathrm{~K}$. 


\section{B-Wing ICP-MS in AL}

Facility: Analytical Laboratory

\section{Description}

The ICP-OES located in B-148 still functions, but has required large amounts of maintenance and replacement parts. Since this instrument is no longer supported by manufacturer service agreements it has gone long periods of time awaiting repairs. Furthermore, this instrument is several generations behind the current models and requires special manufacturing of some consumable parts essential for its use. Current analysis provided by this instrumentation is limited to $\mathrm{Si}$ and $\mathrm{B}$ elementals in non-irradiated fuels. The instrument is not regularly in use, but is heavily used when analyses are required.

\section{Benefit}

It is recommended this instrumentation be upgraded to a current generation instrument with high resolution capabilities, inside of a walk in hood. Use of a HR-ICP-OES would allow for the analysis of halogens and improve the resolution and sensitivity to the elements generally analyzed. The addition of a hood to enclose the instrument would allow for higher activity samples to be analyzed and reduce the load on the A-wing OES, eliminating the tedious process of transferring samples, standards, and checks into Hot Cell \#6 before being transferred into the ICP glovebox. A HR-ICP-OES could afford improved data and lower data analysis time as many of the interferences the plague the current instrument would be eliminated by the improved optics of a HR.

ROM Cost Estimate: $\$ 300 \mathrm{~K}$. 


\section{Tailored Enrichment Capability - Calcine in FASB}

\section{Description}

Research-scale calcine demonstration.

There are currently no commercial sources of enriched uranium oxide beyond approximately $5 \%$ enrichment used in commercial light water reactors. Many recent advanced fuel concepts for accident tolerant fuels as well as advanced reactors require a higher enrichment level. Near term available sources of enrichment uranium are metallic. Although aqueous processing routes could be developed, these would require complex chemical processing equipment, include highly acidic solutions, precipitation steps, followed by calcining to the proper composition and stoichiometry. A more direct route which allows tailoring enrichment would be calcining uranium metal to synthesize uranium oxide. Because this process requires less equipment, does not involve large quantities of acidic solutions it is the preferred method for HALEU ceramic fabrication from currently available uranium metal feedstocks. This technique has not been developed to allow for tailoring U-235 content to desired enrichment. Developing this process will allow experimental quantities of uranium oxide fuel to be fabricated using existing metallic feedstocks, avoiding the additional waste that would be created using dissolution and precipitation Also, development of this process on a laboratory scale will significantly support the development of the process for engineering scale use of HALEU.

\section{Benefit}

Although current LWR fuels are only enriched to 5\%, accelerated testing as well as advanced accident tolerant fuel concepts require much higher enrichments. Establishing this capability will expand our research and demonstration capabilities with fuel forms that contain uranium oxide. Which is the most common fuel used in commercial power generation.

Without this capability impacts to research programs include impeding deployment and testing of advanced LWR fuel concepts. Safety testing of fuels (transient testing) requires higher burned fuel samples. Because these fuels are currently not available they must be produced through irradiation testing. Without being able to tailor enrichments up to HEU (for testing purposes only), production of suitable transient samples will be severely limited and may lead to an inability to qualify new concepts. Being able to confidently say we can produce this kind of fuel meat will help improve our funding opportunities.

ROM Cost Estimate: $\$ 500 \mathrm{~K}$. 


\section{Improved electronic interface for hot cell scales and balances}

\section{Description}

The balances and scales in the HFEF cells are still using the MTG. The balances and scales need an improved electronic interface with facility software to support improved material tracking in-cell.

\section{Benefit}

An improved capability to interface more directly with facility material management software will increase operational efficiency and reduce opportunities for error. The current system requires manual entry of data into the material tracking system after measurements are taken. This slows work progress and introduces risks of error.

ROM Cost Estimate: $\$ 200 \mathrm{~K}$. 


\section{Replace Focused lon Beam (FIB) instrument in the Electron Microscopy Laboratory (EML)}

\section{Description}

Replacement of the EML FIB due to the age of the instrument.

\section{Benefit}

The EML FIB was the second FIB in the world to be used for characterization of irradiated fuels. The EML FIB is fully utilized, and key to the future operation of MFC as a user facility. The EML instrument is used primarily to prepare samples for other advanced characterization techniques such as transmission electron microscopy, scanning electron microscopy, and atom probe tomography, and micromechanical testing. The replacement SEM in EML will be used for multiprogram work, including classified work. These missions require a reliable SEM outfitted with a suite of analytical detectors. The EML FIB instrument is near end-of-life ( $>9$ years old) and experiencing decreased availability because of more frequent maintenance issues. The FIB is $>100 \%$ utilized, and increasing failure rates affect the ability to meet programmatic and milestone commitments.

ROM Cost Estimate: $\$ 1.3 \mathrm{M}$. 


\section{Expanded CNO Capability in AL}

\section{Description}

The LECO model RHEN602 is an inert fusion hydrogen analyzer that is capable of measuring hydrogen impurities in metals, refractories, and other materials common in the nuclear fuel cycle sample. This instrument will support material analysis in a laboratory bench top environment for NS\&T/NR work requiring material composition certification where low level hydrogen analysis is necessary or where small sample sizing becomes a concern.

The LECO model CS844 is a simultaneous carbon/sulfur combustion analyzer that is capable of measuring these impurities in metals, refractories, and other materials common in the nuclear fuel cycle. In particular, carbon is an element of high interest when casting new fuels due to its prevalence in the environment making it one of the major impurities in most materials.

The LECO model ONH836 is a simultaneous oxygen/nitrogen/hydrogen inert fusion analyzer that is capable of measuring these impurities in metals, refractories, and other materials common in the nuclear fuel cycle. The content of each of these elements can vary significantly depending on the material being analyzed and the processes they have been exposed to. This instrument will support material analysis in a laboratory bench top environment for NS\&T/NR work requiring material composition certification.

\section{Benefit}

The hydrogen analyzer is unique in terms of hydrogen analyzers due to its large sample size analysis capabilities. The ability to run samples that are many times the mass of what other inert fusion instruments will provide lower detection levels, down to $0.05 \mathrm{ppm}$, and higher confidence in the sample composition being representative of a material. The carbon/sulfur analyzer will support material analysis in a laboratory bench top environment for NS\&T/NR work requiring material composition certification. The $\mathrm{ONH}$ analyzer is unique when compared to other inert fusion analyzers because it can measure all three elements on one sample. This means less sample is required which helps facility material limits and programs that may be material limited.

ROM Cost Estimate: $\$ 600 \mathrm{~K}$. 


\section{Tailored Enrichment Capability Demonstration - Aqueous Precursor in RCL}

\section{Description}

Develop a research-scale, aqueous-based process to produce HALEU UO2 or precursor solutions for other uranium compounds.

\section{Benefit}

Most available HALEU feedstocks are metallic. This capability will expand the options for conversion to other fuel forms.

ROM Cost Estimate: \$1M. 


\section{Visual Mount Inspection System in the HFEF Containment Box}

\section{Description}

The primary function of the containment box in the Hot Fuel Examination Facility (HFEF) is to prepare mounted ceramic or metallic samples for materialography. Materialographic sample preparation involves subsequent steps of mechanical material removal of each deformation layer from the previous step to reveal the true microstructure of the mounted material. Prior to proceeding to the next step of mechanical material removal the mounted sample must be inspected to ensure the surface finish is free of deformation from the previous material removal step and that the sample is free of preparation artifacts (i.e. scratches, smearing, edge rounding, etc.).

If the surface finish of the mounted sample is not properly inspected prior to materialography and is determined to be unacceptable during light microscopy, costly rework, scheduling, and material transfers must occur. It is estimated that each mounted sample with an unacceptable surface finish costs approximately 20 man hours of operations time to rework the preparation steps. Currently, this inspection is accomplished by the use of a Kollmorgen Model 894 Hot Cell Periscope.

\section{Benefit}

A visual system to inspect mounts during sample preparation is necessary to ensure the efficiency of containment box operations.

The Kollmorgen Model 894 Periscopes were procured and installed in HFEF in the mid -1970s. The Kollmorgen Model 894 Hot Cell Periscope has performed satisfactorily for the purpose of inspecting mounted samples, though it is experiencing intermittent failures from age and extensive use. Repairs to the periscope were completed in 2008 , but the repairs have not restored full system capability.

Kollmorgen has ceased manufacturing of hot cell periscopes and a very limited supply of replacement parts is available. The inspection of mounted samples during sample preparation is key to efficient materialography operations. Failure of the Kollmorgen Hot Cell Periscope would leave containment box operations at HFEF in a vulnerable state.

ROM Cost Estimate: $\$ 1 \mathrm{M}$. 


\section{Develop Digital Radiography Capabilities in HFEF}

\section{Description}

This project installs a digital neutron radiography system at North Radiography Station to increase the quality and throughput of radiography campaigns and allow routine and efficient neutron tomography.

\section{Benefit}

Neutron imaging is an ideal method for rapidly evaluating fuel performance and diagnosing material and fuel failures. Tomographic neutron imaging provides a three-dimensional data stream from which detailed information of fuel and material performance and quantitative dimensional data can be acquired. Coolant channel dimensions, ${ }^{235} \mathrm{U}$ depletion, and fuel swelling data can be obtained. The currently used film transfer radiography method provides high quality radiographic images, but is time consuming, expensive, and film development generates hazardous waste. For example, even with recently improved NRAD throughput, a FY-16 tomography campaign of a four-foot long fuel element required 3 weeks to complete. Digital neutron detection can increase radiography throughput by at least an order of magnitude by eliminating the film transfer, development, and scanning process.

This project will design and deploy a digital neutron detection system for imaging irradiated objects by testing the detector response to the gamma-contaminated neutron beams at NRAD and to high gamma doses. Currently, no facility in the world has the capability for digital neutron detection of irradiated fuel and materials. Experimental digital detectors have been shown to have increased resolution and are being further developed to allow automation and reduce the time required to generate images. Neutron detectors developed at the University of California-Berkeley and supplied to other neutron imaging facilities worldwide are being tested in a high gamma field at NRAD. Initial testing resulted in the first fully digital neutron radiographs ever acquired at NRAD.

Status: Testing of digital neutron detectors and system design is currently being conducted using LDRD funding in conjunction with UC-Berkeley.

ROM Cost Estimate: $\$ 2.5 \mathrm{M}$. 


\section{Replacement of the AL Thermal Ionization Mass Spectrometer (TIMS)}

\section{Description}

The ability to perform precise and accurate analyses for Material Control and Accountancy (MC\&A) samples is a vital part of several processes at MFC. The traditional method of performing those types of measurements at the INL and across the DOE complex is the TIMS. The instruments are simultaneous isotope ratio instruments that use very well characterized spike material (by New Brunswick Laboratory, NBL) and isotope dilution mass spectrometry to perform assays on Uranium and Plutonium. The total assay of a TIMS analyses for $\mathrm{U}$ and $\mathrm{Pu}$ is $<0.5 \%$, which is consistent with the international target values.

The current Triton TIMS unit has been in operation since 2009. While the instrument is currently functioning, it is nearing the end of its support from Thermo, the instrument manufacturer. In addition, new advances in detectors, ion optics and filament temperature controls make the current state of the art superior to the currently installed instrument. As the need for improved detection capabilities increases, and multi-laboratory exercises within the DOE complex continue, it is vitally important that the AL have equivalent instrumentation and capability to perform on the same level as the other national laboratories. In addition, for programs that want data consistency, by consistent analyses since the $1980 \mathrm{~s}$, it is important to have the TIMS capability available. Hence, the replacement of the Triton TIMS units is necessary.

\section{Benefit}

The replacement of the TIMS unit will allow for better, more timely and consistent MC\&A measurements for $\mathrm{U}$ and $\mathrm{Pu}$. Another direct benefit of the addition will be the use of the Triton instrument for method development and fundamental research activities (while the instrument is functioning). The addition of another instrument will give flexibility for research activities that are not currently allowed because the instrument must be maintained for the MC\&A activities. These could include advancements in sample introduction, method development for low level detection and modification of ion optics and detector assemblies for improved performance.

Status: A rough order of magnitude cost estimate has been developed. Lead time on the instrument is approximately $6-9$ months after placement of the order.

ROM Cost Estimate: \$2M. 


\section{Versatile Fuel form Capability - Metal Alloy Atomization in AFF}

\section{Description}

Applied science scale $(<5 \mathrm{~kg})$, Atomization equipment suitable for radioactive materials powder handling and processing glovebox line in AFF.

Many advanced manufacturing techniques will require powder feedstock. The development of highdensity dispersion fuels and advanced fuel concepts will also require powder development and manipulation capabilities.

Production of printed fuels will require a supply of metal fuel alloy powders with tightly controlled morphology and size distributions. Atomization has proved to fill this need in the powder metallurgy industry and has been used in other programs for dispersion fuels which also require tightly-controlled particle size and morphology.

Atomization will also provide fuel feedstocks for other advanced concepts such as coated and consolidated dispersion fuels. An example of this could be a U-Zr fuel coated with a fuel-cladding chemical interaction barrier dispersed in a metal matrix. Another advanced concept that has been proposed is sphere-pac fuels where the fuel particles are simply "poured" into the cladding. Such fuels have been proposed as high burnup fuels because of the ability to tailor fuel smear density, as well as being applicable to remote processing. An advantage of particle fuel will also be reduction of wastes produced during fabrication, such as molds. "Sphere-pac" concepts have been proposed for remote fabrication as well because of the ease of remote fuel loading.

Due to the unique rapid solidification properties of atomization, unique microstructures and alloy compositions may be possible. An example of the utility of this approach is with the current fuel additive work to control fuel-cladding interdiffusion. Rapid solidification will ensure the additive material, which may not be miscible in the matrix material, will be more uniformly dispersed to ensure it will capture and combine with the produced fission products.

\section{Benefit}

This capability will allow us to more fully utilize our existing processes and vastly expand our advanced manufacturing opportunities. With the advanced manufacturing processes and with the novel fuel forms and alloys possible unique advanced fuel forms development will be greatly enhanced.

Many of the advanced manufacturing techniques require a source of spherical metal powder feedstock. A source of this material does not exist in the US, therefore without this capability development, advanced manufacturing cannot be fully implemented for fuel fabrication at the INL or within the DOE complex as a whole.

ROM Cost Estimate: \$2M. 


\section{In-Situ Micromechanical Testing for Titan TEM (Picoindenter) in IMCL}

\section{Description}

Install a TEM (Transmission Electron Microscope) Picoindenter in the IMCL.

\section{Benefit}

A TEM Picoindenter is uniquely suited for the investigation of nanoscale mechanical phenomena. Performing these types of studies while imaging at high resolution in the TEM provides unambiguous differentiation between the many possible causes of force or displacement transients which may include dislocation bursts, phase transformations, spalling, shear banding, or fracture onset. This information couples directly to deformation models that are important to understanding material behavior under irradiation. The picoindenter is a multi-programmatic instrument for which work will be prioritized based on program mission priorities and milestones and impact of applied and basic science.

The development of nuclear energy has suffered, over the last three decades, from a lack of understanding of the in-service behavior of materials. In all sectors of technology, including nuclear energy, the in-use degradation of materials is life limiting. The acquisition of picoindenter will allow for the continued development of the understanding of the complex evolution of the mechanical properties of materials under irradiation.

ROM Cost Estimate: $\$ 450 \mathrm{~K}$. 


\section{Update PGS in HFEF}

\section{Description}

The PGS motor and control system was upgraded in 2009 in order to eliminate electronic noise interfering with the detector and to replace outdated components. Positioning motors, sensors, cables, control electronics, software, and some hardware were the obsolete components that were replaced. This effort was only partially completed. The Y-motor install was not finished and the magazine support was not upgraded. It also included efforts to prepare the system for new detection equipment and Compton suppression needed for future programs that was installed in 2011. Following that, the detection equipment was upgraded again to a digital system in 2015. The stage experienced an accidental collision with the EMM bridge in early 2017 that resulted in an upgrade to the gripper box. The most recent upgrades were completed through Phase 1 and 2 in mockup late 2017 that included an all new control cabinet and accompanying OCS changes, magazine support and rotate, Y-motor and cabling. The hardware has all been stored waiting on funding to complete.

The current effort requires the following high-level activities for completion. Equipment should be brought back to mockup for a quick checkout. The old cabinet CP-110 on the second floor of HFEF needs removed, and the new cabinet installed and wired. The new magazine and motors need transferred in-cell and installed. The $6 \mathrm{M}$ table will need relocated to access the breakout box and y-motor mount. Once all the hardware is installed the software and operation can be qualified with a Phase 3 procedure.

\section{Benefit}

Precision Gamma Scanning is one of the most utilized non-destructive exams in HFEF. Gross and isotopic data provided from PGS analysis is most commonly used for determining burnup, and paired with neutron radiography, is used to collect dimensional information making decisions on destructive examinations. This system is typically scanning experiments nonstop. Upgrade of the PGS will restore capabilities that have been lost.

The PGS is currently meeting all of the program requirements but as components age they will need replacement. The y-motor has been inoperable for almost 10 years and should be replaced to offer more adjustment in scan parameters (reducing solid angle scatter). The X-motor was damaged during the VEM upgrades and is still functional but in a fragile state. The magazine rotate has also been inoperable for some time and that capability should be restored.

ROM Cost Estimate: \$1M. 


\section{Ion Chromatography in $\mathrm{AL}$}

\section{Description}

Ion chromatography (IC), also called ion-exchange chromatography, is used to separate and quantify many major cations, such as magnesium, calcium, lithium, sodium, and ammonium, as well as major important anions such as fluoride, chloride, carbonate, nitrate, and sulfate. As a form a liquid chromatograph, it is used to characterize solutions of dissolved solids, such as those typically measured in the Analytical Laboratory (AL). The technique uses a resin-filled column to effect the separation of the ions based on their disparate interactions (absorption followed by desorption) with the resin.

\section{Benefits}

The AL currently possesses the ability to measure a limited number of anions, such as chloride, using an ion-selective electrode. This technology requires a separate electrode for each ion of interest, and does not provide the separations ability or the precision of IC. With IC instrumentation, the AL would not only be able to provide precise, quantitative data on the concentrations of a host of important cations and anions, but it would also be able to separate complex mixtures of species common in its work on nuclear fuels. The ability to separate and identify organic cations in addition to the inorganic species already mentioned would make possible support for fundamental and applied actinide and fission product chemical research.

The AL currently follows technically challenging procedures for the measurement of certain anions, such as iodide; and some species, such as fluoride are not currently accessible to its methods. The addition of IC instrumentation would allow for simplified and safer analyses of major species and provide customers with greater choices and finer details about their materials. Without the addition of IC capabilities, the AL would be unable to adapt to the needs of its current and future customer base in the continually growing regulatory and scientific requirements for characterization of nuclear fuels and waste.

ROM Cost Estimate: \$200K. 


\section{Replace Leitz Metallograph in HFEF MetBox}

\section{Description}

The Leitz MM 5 RT metallograph is over 35 years old (the microscope design actually dates back to 1965 ) with the most recent upgrade to the step-motor stage control capability having been completed in 2009. At over 35 years of age, the microscope components are no longer replaceable and the metallograph is in need of replacement.

\section{Benefit}

Replacement of the metallograph will restore capabilities that have been lost as well as improve reliability to continue supporting program work. At over 35 years of age, the microscope components are no longer replaceable. Function of the step-motor stage position has degraded to the point that precise positioning of the stage to view certain regions of a given specimen is nearly impossible. This has made it very time consuming and difficult to collect micrographic tiles of a specimen to later construct into a montage of the entire specimen. The camera, upgraded several years ago is obsolete and the quality of the images relative to that generated by new state-of-the-art microscopes, are inferior. This is part due to facility translated vibrations, the inability of the stage to hold its position and the aging optics involved in the system.

ROM Cost Estimate: $\$ 1.5 \mathrm{M}$. 


\section{Develop NRAD Neutron Diffraction Capability in HFEF}

\section{Description}

This project designs and installs a neutron diffraction system that will quantitatively improve irradiated material characterization. The diffractometer will be installed at NRAD (Neutron Radiography reactor) north beam line.

\section{Benefit}

Neutron diffraction is a powerful tool that is complimentary to e-beam methods for the characterization of nuclear materials. At the INL, advanced microscopy techniques are used to characterize the crystal structure of irradiated nuclear fuel and materials. These methods provide detailed microstructural information on a very small sample, but require difficult sample preparation. Neutron diffraction provides more precise information on lattice parameters, atomic positions, and the stress state in a bulk material. Neutron diffraction and data analysis can generally be conducted in less time than electron microscopy. The use of neutron powder diffraction at NRAD has the potential to significantly enhance the basic and applied science of nuclear fuels for current DOE programs as well as scientific and commercial customers.

The capability for neutron (or x-ray) diffraction of high activity materials and irradiated fuels does not exist in the United States, and only at a few places in the world. Current neutron diffractometers rely on high flux sources (the HFIR and NBSR reactors and the SNS, for example) at user facilities that do not accept high activity materials or fuel. Since neutron flux at the sample location of NRAD north beam line is low relative to these reactors, a polychromatic (white) beam diffraction approach has been selected in consultation with neutron scattering scientists at ORNL and MIT. The use of a white beam provides many diffraction events simultaneously and uses an analyzer crystal to select the specific neutron wavelengths that are collected by the detectors.

Neutron diffraction coupled with simultaneous neutron imaging will provide closely correlated information about material structure and performance.

The feasibility and system design of neutron diffraction using the NRAD reactor is currently being explored with MIT and ORNL. Design concepts and feasibility studies will be completed in FY-17.

ROM Cost Estimate: $\$ 2.5 \mathrm{M}$. 


\section{PIPS II (Precision lon Polishing System) for Sample Preparation for Microstructural Characterization in the IMCL}

\section{Description}

One of the most important aspects of microsctructural characterization is sample preparation. The PIPS II is a broad beam ion milling system that is a powerful tool for TEM (Transmission Electron Microscopy) specimen preparation. It uses a focused argon ion beam to precisely mill TEM samples until a small hole is created in their thinned area. The low voltage ion beam is used for the final stage of sample preparation to remove surface damage caused by high voltage ion beam. Although FIB (Focused Ion Beam) systems are provide revolutionary capability for site specific sample preparation, the PIPS is useful for milling larger samples and removing damage cause by higher energy ions beams.

\section{Benefit}

Without the PIPS II tool, neither TEM sample preparation and FIB instruments FIB instruments are optimally utilized. The PIPS II system provides an inexpensive alternative to the FIB systems for the preparation and finishing of some samples. It relieves some of the workload from the FIBs, reducing backlog and increasing access.

ROM Cost Estimate: $\$ 300 \mathrm{~K}$. 


\section{Versatile Fuel Form Capability Phase 2: Continuous Casting in AFF}

\section{Description}

Continuous casting of solid and annular slugs.

Reactor developers desire to develop and qualify metal fuel designs that do not require an annular sodium bond between fuel and cladding, because the sodium complicates the disposition path for such fuels. Annular fuel, intimately bonded to cladding is one proposed design to remove the sodium from the fuel elements. Additionally, annular fuels have been proposed as high burnup low smear density fuel. Annular fuels can be made using an extrusion process; however, extrusion with a transuranic fuel alloy or even a transuranic contaminated fuel alloy is more difficult due to the radiological controls needed to protect production personnel. Also, in order for fuels to reach high burnup levels a low smear density, or thin walled are required which may not be as amenable to fabrication through extrusion. Although annular continuous casting of uranium has not been demonstrated, copper tubing has been continuously cast on an industrial scale, this same process can be made use of for casting of annular fuels. Continuous casting of uranium alloys has been proven feasible, however, these demonstrations produced rods significantly larger diameter than typical fuel diameters. Studies have shown that casting of a prototypic fuel diameter is feasible. In addition to annular fuels other complex fuel shapes may also benefit through the continuous casting process because a mold is not needed which simplifies the fabrication process, and reduced waste.

\section{Benefits}

Expand research capability and open up commercially viable fabrication options for numerous fuel forms. Reduced waste production during fuel fabrication activities (no molds). Consistent microstructures throughout the fuel due to consistent thermal gradients during casting. Annular fuel production without introducing a textured product which then requires additional processing. Supports advanced fuel forms applicable to the VTR.

There is an increasing interest in metallic fuel forms for all reactor types. The technology could significantly reduce the risk to market for these fuels.

ROM Cost Estimate: $\$ 2 \mathrm{M}$. 


\section{AL Gas Chromatograph}

\section{Description}

Gas chromatography (GC) coupled with a range of possible detection techniques, such as thermal ionization, flame ionization, and mass spectrometry, provides the ability to measure gaseous elements and compounds, as well as volatile liquids and solutions of solids. GC instrumentation is standard in most analytical laboratories and provides access to measurements currently outside the capabilities of the Materials and Fuels Complex Analytical Laboratory (AL). The GC chromatograph consists of one or more coiled separations columns that are housed in an oven providing the temperature control necessary to fine tune separations and maintain the gaseous state of the species under investigation. The columns themselves are highly customizable, also contributing to the ability of GC to effect difficult separations. The separated analytes, as they elute from the column, are then identified and characterized by the detection techniques mentioned above.

\section{Benefit}

The AL currently operates a high-resolution gas mass spectrometer (GMS), some of whose functions overlap with those of a GC. There are some important differences, however, that make having both types of instruments advantageous. For example, the GMS requires an additional, expensive heated inlet system for the measurement of volatile liquids, and the introduction of these types of samples presents technical challenges. On the other hand, rapid introduction of volatile liquids to a GC is straightforward because of its simple oven apparatus and preheated columns. Furthermore, the measurement of solutions containing solids with molecular masses up to c. 300 daltons is possible in GC instruments but not possible for the GMS. The ability to measure such solutions provides a powerful tool that the AL does not currently possess for the characterization of small molecules. The ability to measure small molecules by GC opens opportunities for collaborations on research and development on speciation studies, particularly pertaining to the complexation of actinide elements critical for environmental remediation and decontamination efforts.

Measurement of species in the GC mass range fills a gap in capability between atomic species, currently measured by a suite of inductively-coupled-plasma (ICP) instruments in the AL, to molecules heavier than 300 daltons, which are able to be characterized by the AL's high performance liquid chromatograph (HPLC).

The AL has already been forced to turn down requests for analysis of certain gaseous mixtures or volatile liquids, such as moisture content analyses, because of the lack of GC instrumentation. Additionally, some analyses that are currently carried out on the GMS could more rapidly and affordably be performed on a $\mathrm{GC}$, thereby also reducing the time required to provide results from the GMS. As mentioned above, GC instrumentation opens new fields of collaboration in nuclear research. Without GC capabilities, the AL would be at risk of stagnation in its gas analyses, forcing potential customers and collaborators to pursue partnerships with other laboratories in areas in which the AL holds extensive expertise.

ROM Cost Estimate: $\$ 400 \mathrm{~K}$. 


\section{Raman Spectroscopy for Nuclear Fuel and Cladding Characterization}

\section{Description}

Raman spectroscopy is used for the analysis of vibrational, rotational and other low-frequency modes in crystals and molecules. It is a well-established, non-destructive characterization technique widely applied in several fields such as nanotechnology, biology, environmental science, forensics, pharmaceutical analysis etc.

Raman spectroscopy of nuclear materials has seen a broad development in the last two decades. It is particularly attractive in nuclear fields as features like (1) limited sample preparation needs, (2) necessity of a very small amount of sample, and (3) nondestructive character are key features to minimize radiation doses and potential release of radioactive material. In addition, application of optical fiber structures makes possible to perform non-contact measurements, avoiding installation of most of the equipment in confinement spaces for radioactive materials (e.g., glove boxes), thus containing installation and maintenance costs.

One of the main advantages of Raman spectroscopy is its ability to record spectra in short time with minimal sample preparation and to obtain information regarding both chemical and physical properties (e.g., crystalline disorder). It can be applied to a variety of materials and material forms, including thin films, powders, fibers, embedded layers, gases and liquids.

Several high quality off-the-shelf Raman spectrometers are available that meet requirements for nuclear fuel and material characterization. In-cell installation is relatively straightforward because of the ability to use optical fiber probes.

The development of this characterization tool would support many MFC R\&D focus areas, as the technique offers a wide spectrum of potential applications:

1. Physical and chemical characterization of advanced fuels (including possible impurities)

2. Characterization of waste forms, fission products, nuclear fuels, actinide-bearing materials

3. Fingerprint and identification of feedstocks for forensics applications

4. Characterization of corrosion products of nuclear fuel claddings and structural materials

5. Determination of oxidation stability of nuclear materials.

\section{Benefit}

Not having access to this common characterization tool limits progress in many nuclear energy R\&D focus areas, such as:

1. Physical and chemical characterization of advanced fuels (including possible impurities)

2. Characterization of waste forms, fission products, nuclear fuels, actinide-bearing materials

3. Fingerprint and identification of feedstocks for forensics applications

4. Characterization of corrosion products of nuclear fuel claddings and structural materials

5. Determination of oxidation stability of nuclear materials.

ROM Cost Estimate: $\$ 300 \mathrm{~K}$. 


\section{Appendix C}

\section{Detailed Descriptions of TREAT Instrument Capability Activities}


MFC FIVE-YEAR INVESTMENT STRATEGY

Appendix C

Detailed Descriptions of TREAT Instrument Capability Activities 


\section{Appendix C}

\section{Detailed Descriptions of TREAT Instrument Capability Activities}

\section{Transient Testing Experiment Preparation and Handling in MFC-723}

\section{Description}

TREAT experiment vehicles are complex systems that require dedicated equipment to support assembly and checkout, as well as disassembly and preliminary examination, prior to shipment to INL PIE facilities. Modifications to MFC-723 are being considered to provide a co-located facility ideal for crosscutting TREAT experiment support.

Many TREAT experiments will be conducted on low activity samples (fresh fuel or small samples) that will require minimal shielding during post-transient handling. A specialized test train assembly facility supporting TREAT, similar to the Test Train Assembly Facility (TTAF) support for the Advanced Test Reactor (ATR), will allow for rapid assembly, modification, and repair of test rigs prior to installation in the reactor.

\section{Benefit}

Infrastructure upgrades include installation of a suspect ventilation system and shielded glove box in MFC-723. Initial concept design work was funded by IFM. The ventilation system upgrades will provide the required environmental control for an experiment support system. The shielded glove box will support disassembly of contact handled tests and workspace for assembly of non-irradiated test assemblies. Colocation of this area is essential to optimal support of experiments and integration of system design and performance testing with TREAT operations staff.

A shielded glove box will also provide the capability of handling higher activity samples. AFC has funded the design for this. This cell will include a device that allows the installation of instrumentation into irradiated fuel pins that have been refabricated at HFEF into the proper length for testing in TREAT. See Appendix C Item 5 for more detail on the reinstrumentation/refabrication bench.

ROM Cost Estimate: $\$ 2.5 \mathrm{M}$ (an ATR Test Train Assembly Facility type capability)

ROM Cost Estimate: \$9M (MFC-723 infrastructure and shielded glove box) - final funding source has not been determined 


\section{HFEF Capsule Experiment Handling Capability}

\section{Description}

Facility readiness activities are required to support TREAT capsule experiments including:

A hot cell system to disassemble experiments that became significantly radioactive during irradiation at TREAT. A general purpose system will be developed that is the foundational interface for design of future drop-in TREAT capsules.

\section{Benefit}

A hot cell system is needed to assemble experiments that are already significantly radioactive prior to irradiation in TREAT. A general purpose system will be developed that is the foundational interface for design of future drop-in TREAT capsules. This system will provide provisions for operational checks on the test device before transport to TREAT.

Facility assessment and cost estimates were completed in FY-17 and are documented in TEV-3093. A final funding source has not been determined.

ROM Cost Estimate: $\$ 3 M$. 


\section{HFEF TREAT Loop Handling Capability}

\section{Description}

Re-establishing TREAT loop handling testing capability will require an assembly and checkout station to support both water and sodium loops in HFEF. Flow tube assembly will be performed at HFEF Stations 5D and 4D. Loop assembly will be performed directly into the cask container.

\section{Benefit}

This station will support full operational testing of the loop before shipment to TREAT for transient testing. Some of the infrastructure to support the sodium loop is still installed at HFEF but must be assessed and refurbished.

Facility assessment and cost estimates were completed in FY-17 and documented in TEV-3093. A final funding source has not been determined.

ROM Cost Estimate: $\$ 3 \mathrm{M}$. 


\section{TREAT Hodoscope}

\section{Description}

A key nondestructive examination system at TREAT is the Fuel Motion Monitoring System, also called the Hodoscope. The Hodoscope is a fast-neutron imaging system mounted at the reactor's north beam port that provides real-time information about the location, deformation, and relocation of experimental fuels held within test devices during high-power transient events. The system incorporates hundreds of channels of data operated in parallel and is capable of recording movement at sub-millisecond timescales over a large field of view. It is capable of simultaneously imaging an entire advanced-reactor fuel assembly. However, individual image pixels within the hodoscope are coarse and are not optimized for studies of small-scale effects in single fuel pins, such as the quantification of minor axial fuel swelling or fuel-clad bowing. New investments are needed to design and develop a new FMMS optimized for the measurement and analysis of smaller-scale phenomena in single pins, with higher image-plane spatial resolution, higher signal rates, and better signal-to-noise performance than the current hodoscope.

\section{Benefit}

Effective use of TREAT requires continuous development of fast neutron hodoscope to support evolving experimenter objectives. This development requires three phases of capability recovery outlined below;

Limited-View Hodoscope - Prior to being placed in standby, the TREAT hodoscope was capable of accommodating a large field of view $(1.2 \mathrm{~m} \times 0.66 \mathrm{~m})$ using two complementary sets of 360 individual 'pixel' sensor channels. However, early TREAT experiments are not expected to utilize this full field of view. As such, a sub-set of 100 proton scintillators ('Hornyak buttons') where fully refurbished and coupled to a modern data acquisition system to enable performance testing and technique development during early reactor operations. Testing and qualification of the hodoscope is currently being performed using this system.

Full-View Hodoscope - Use of the hodoscope for full-size experiments requires that all imaging slots be activated. Detectors will be refurbished (or procured) and qualified to support all 360 hodoscope detectors. This will likely include reactivation of the remaining Hornyak buttons, potential refurbishment of existing methane proportional counters, and design/fabrication/installation of the next generation detectors. The data acquisition system required to support the full device will also be designed and installed. The reactivation of additional Hornyak buttons is currently in progress.

Next Generation Hodoscope - To further support real-time monitoring of fuel behavior during transient operation, a next generation hodoscope with improved spatial resolution is required. Concept development, detailed design, and deployment of such a device are a long-term undertaking that will require sustained attention for several years to fully implement.

Like other specialized nuclear science instruments, the TREAT fuel motion monitoring system will require the long-term support of an instrument scientist.

Reactivation of the limited view hodoscope was achieved in FY-17 just prior to TREAT restart. A performance assessment of the hodoscope and TREAT is currently underway. Full view detector reactivation is currently underway. A final funding source has not been determined.

ROM Cost Estimate: \$5.4M. 


\section{Remanufacturing Bench for Irradiated Fuel Pins in HFEF and MFC- 723}

\section{Description}

Testing of irradiated LWR fuel samples in TREAT (or ATR) requires removal and resealing of samples extracted from full-length fuel pins irradiated in commercial power reactors. As nuclear fuels are most susceptible to failure in their degraded end-of-life condition, access to and use of this material type is crucial to the success of any transient testing program. In addition, capability to install advanced instrumentation is a crucial element of the remanufacturing bench/process to access valuable data streams from irradiated fuel.

\section{Benefit}

Devices of this type have been developed for use by virtually all peer nuclear testing institutes around the world and can be procured for use. Two versions of these specialized devices are required to enable this process.

A first device targeted for HFEF is required that simply allows for rod sectioning, extraction of excess fuel pellets, installation of new end plugs, and re-pressurization of the pin.

A second device targeted for MFC-723 that allows for the installation of instrumentation will be required for further scientific and qualification studies.

Procurement activities are currently underway to acquire this equipment from Halden. Cost share between NE-42 and NE-5 is proposed.

ROM Cost Estimate: $\$ 3.7 \mathrm{M}$. 


\section{Transient Science Modular Irradiation Vehicle (MARCH System) Advanced Modules, Including MARCH-SERTTA}

\section{Description}

The Minimal Activation Retrievable Capsule Holder (MARCH) is a modular irradiation vehicle system designed to enable cost-effective and high throughput irradiations in TREAT. By using simplified boundary conditions in small capsule layouts, the MARCH system is ideal for separate effects and phenomena identification tests to progress fundamental transient science, development of advanced fuel performance models, and rapid screening of advanced fuel concepts.

\section{Benefit}

When used with small, fresh fuel samples, low-activation structural materials and typically-brief TREAT irradiations combine to enable PIE within weeks of irradiation. Electric preheat modules enable irradiations at conditions representing current-fleet and advanced reactor concepts.

The foundational structure and baseline test modules, originally developed under LDRD and later adopted by the NTRD program for early-phase ATF testing, were deployed in FY-18. With this initial investment complete, future efforts will develop other enhanced transient science capabilities via new irradiation modules. Future module design and deployment will enable static sodium heat sink tests, transient water boiling investigations, and advanced in-situ optical instruments all to support a variety of nuclear fuel technologies including rodlets, plates, compacts, and molten uranium salts. Cost share between NE-42 and NE-5 is proposed.

ROM Cost Estimate: $\$ 6 \mathrm{M}$.

\section{The MARCH System}
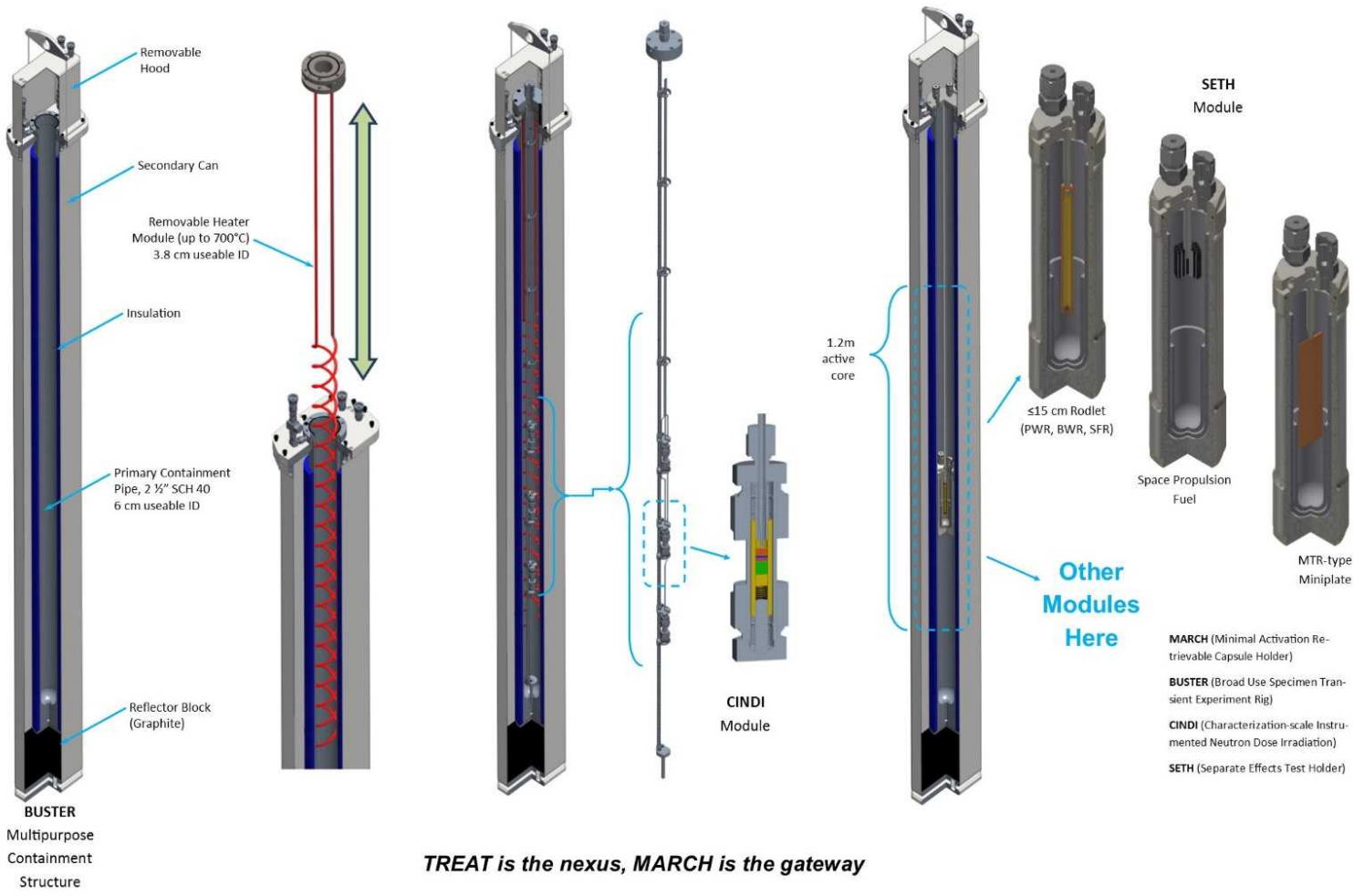

TREAT is the nexus, MARCH is the gateway 


\section{TREAT Recirculating Sodium Transient Irradiation Loop}

\section{Description}

More-recent historic fuel safety research performed in TREAT was dominated by tests on sodium fast reactor specimens within small recirculating sodium loops. The most-recent rendition of this capability, termed the Mk-III sodium loop, will serve as a pattern for a modern version. Recent advances in materials and instrumentation, as well as loss of historic supply chain for some unique liquid metal-based component in some cases, will be addressed in the future sodium loop.

\section{Benefit}

This recirculating sodium device, which allows for irradiation under prototypic liquid metal reactor thermal hydraulic conditions, is critical to conducting tests and evaluating 'post-failure' phenomena, including fission product release and fuel relocation. The sodium loop will be crucial instrument in licensing sodium-cooled fuel designs for deployment of advanced reactors.

Current project to reestablish a modern version of the Mk-III loop is underway. INL is partnering with an industry partner for this effort. This is currently IFM funded.

ROM Cost Estimate: \$12M.

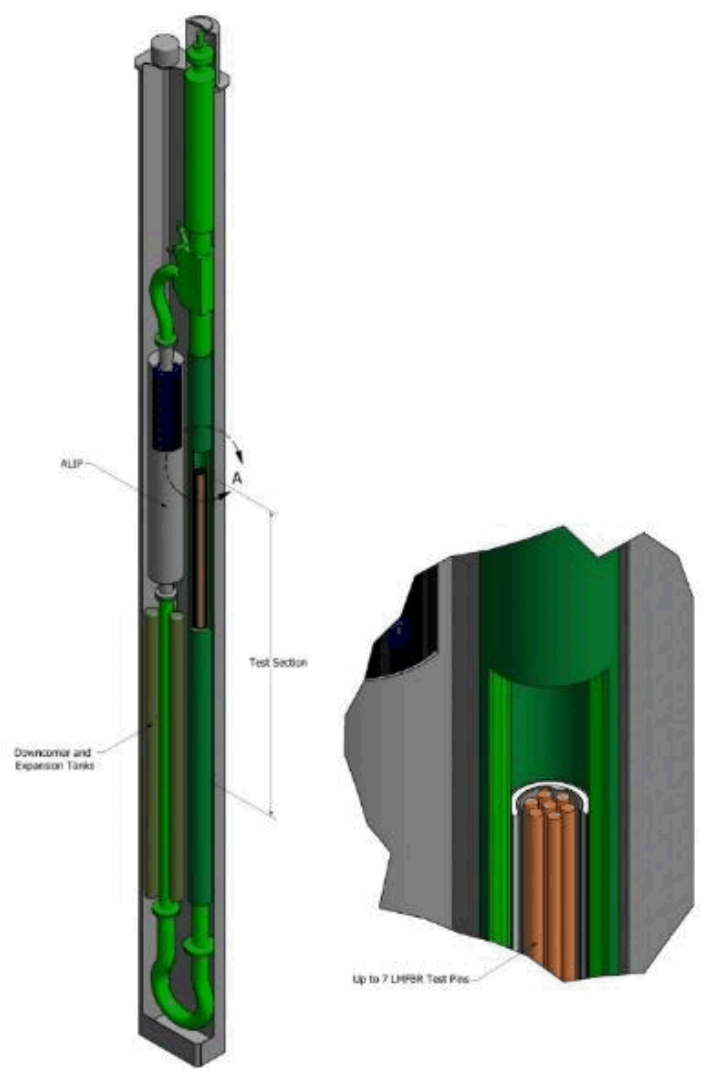




\section{TREAT Large-Capsule PWR Transient Irradiation Vehicle (Super- SERTTA)}

\section{Description}

Super-SERTTA is a scaled up version of MARCH-SERTTA will allow for single rodlets up to $1.2 \mathrm{~m}$ in active fuel length. More importantly, this geometric layout greatly facilitates insertion of pre-irradiated fuel rods via hot cell operations while providing greater access for in-situ instrumentation. While certainly capable of fresh fuel tests, the Super-SERTTA capability is needed to access enhanced data opportunities for high-value pre-irradiated specimens.

\section{Benefit}

This enlarged layout and modular test train layouts enable Super-SERTTA to accommodate TREATbased simulation of pulse type reactivity initiated transients with very narrow pulse widths or to blowdown from pressurized water to steam conditions representing loss of coolant accidents. An enhanced natural convection layout enables increased capabilities for establishing more prototype temperature distributions and stored fuel energy to simulate accidents that are postulated to initiate from full power operations in nuclear plants. This same natural convection layout also enables in-situ heat balance measurements for increased confidence in core-to-specimen power coupling for high-value preirradiated specimens where uncertainties in end-of-life isotopic composition can increase uncertainty in nuclear heating predictions.

The Super-SERTTA is currently in conceptual design. Proposed funding source is NE-42.

ROM Cost Estimate: \$6M.

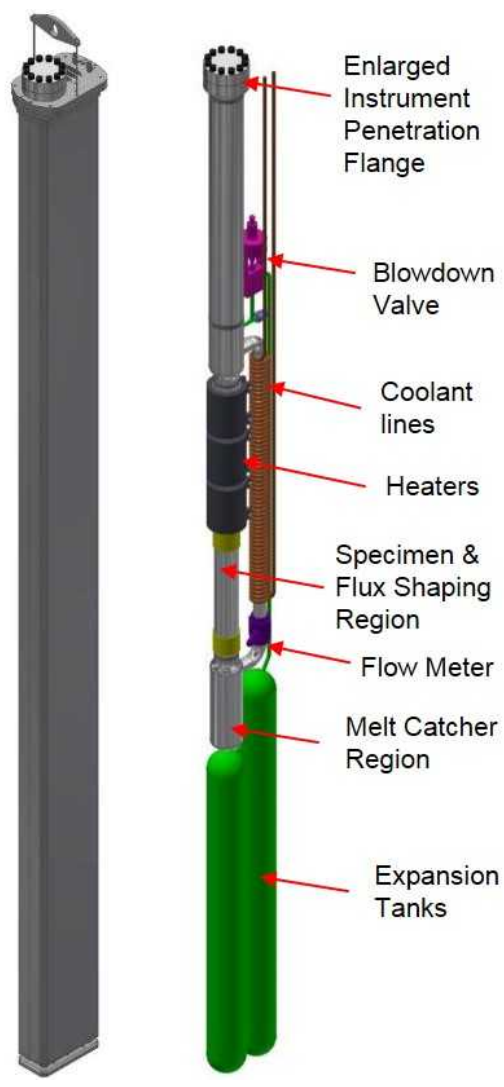




\section{Recirculating PWR Transient Irradiation Loop (TWERL)}

\section{Description}

The TREAT Water Environment Recirculating Loop (TWERL) will take all of the capabilities of the preceding Super-SERTTA device, but will add two crucial capabilities including: (1) A pump for full forced convection and (2) the ability to accommodate small fuel rod bundles.

\section{Benefit}

The TWERL will be needed for the most faithful representation of water-cooled reactor plant conditions for evaluating "post-failure" phenomena, including fission product release and fuel relocation. These types of tests, based on systems used in the Power Burst Facility, are essential in completing the qualification and licensing case for new fuel designs. The presence of a pump will necessitate that the TWERL be cylindrical in form and require modification of a few facility interfaces, including new shaped core graphite fillers, enlargement of the rotating shield plug opening, and modification to the HFEF-15 upper shield ring.

Conceptual design (30\%) of the TWERL system was completed in FY-15. Significant design efforts are planned to commence in FY-20.

ROM Cost Estimate: $\$ 11.5 \mathrm{M}$.
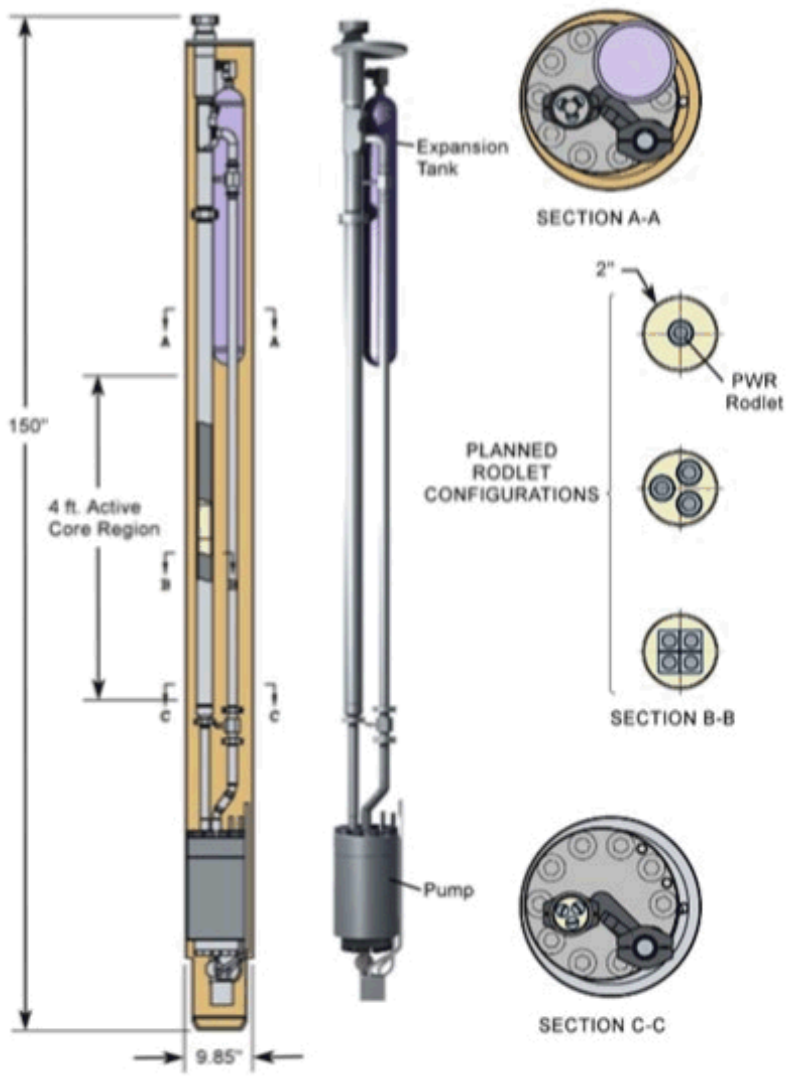


\section{TREAT Multi-pin Test Vehicle}

\section{Description}

The TREAT Water Environment Recirculating Loop (TWERL) will provide testing capabilities to accommodate testing of small fuel rod bundles in water-cooled plant conditions. The multi pin test vehicle will provide testing capability for larger LWR fuel bundles to provide a more accurate representation of pin-to-pin interactions in a LWR fuel bundle.

\section{Benefit}

The system will be capable of irradiating a 3-pin by 3-pin bundle providing a center pin that is completely surrounded by other fuel pins providing proper flow characteristics and fuel pin relationships during testing. The multi-pin test vehicle will build on the TWERL design and is the logical progression of LWR fuel testing in TREAT.

The multi-pin test vehicle will build on the TWERL design and begin design in FY-21 with completion expected in FY-23. Funding source is to be determined,

ROM Cost Estimate: \$4M. 


\section{Advanced In-Reactor Instrumentation for TREAT}

\section{Description}

State-of-the-art and cutting-edge transient testing capability at the TREAT facility requires a wellcoordinated and innovative instrumentation development and qualification program to support near-term and future objectives. Advanced instrumentation is key to unraveling the complex multiphysics involved during transient irradiation experiments including development and validation of modern modeling and simulation tools. In addition to state-of-the-art, next-generation sensors require development for obtaining critical data including neutron flux (energy deposition), temperature, mechanical behaviors such as fuel deformation and coolant behaviors, fission product transport, and advanced materials characterization for properties, microstructure, and chemistry.

\section{Benefit}

Integration of these devices into fundamental TREAT experiment vehicles and in-reactor testing is a critical and demanding component of the required R\&D to establish these technologies. The fuel safety research requires $R \& D$ and qualification of several advanced instrument technologies to meet near-term experiment programmatic goals while establishing the base measurement capabilities (state-of-the-art) for next-generation experimentation. State-of-the-art instrumentation capabilities includes devices to measure neutron flux (energy deposition), temperature, and dimensional changes (assuming bulk fuel movement and relocation is measured by the TREAT hodoscope) for LWR and SFR fuels and environments. Fission product transport and other advanced materials characterization technologies represent strategic areas of development measurement categories.

Advanced instrumentation development is currently being supported from NE5 and NE4. Additional funding is pursued thru competitive awards from NSUF, NEET, and NEUP.

ROM Cost Estimate: \$9M. 